\title{
Flow Velocity, Water Temperature, and Conductivity in Shark River Slough, Everglades National Park, Florida: June 2002-July 2003
}

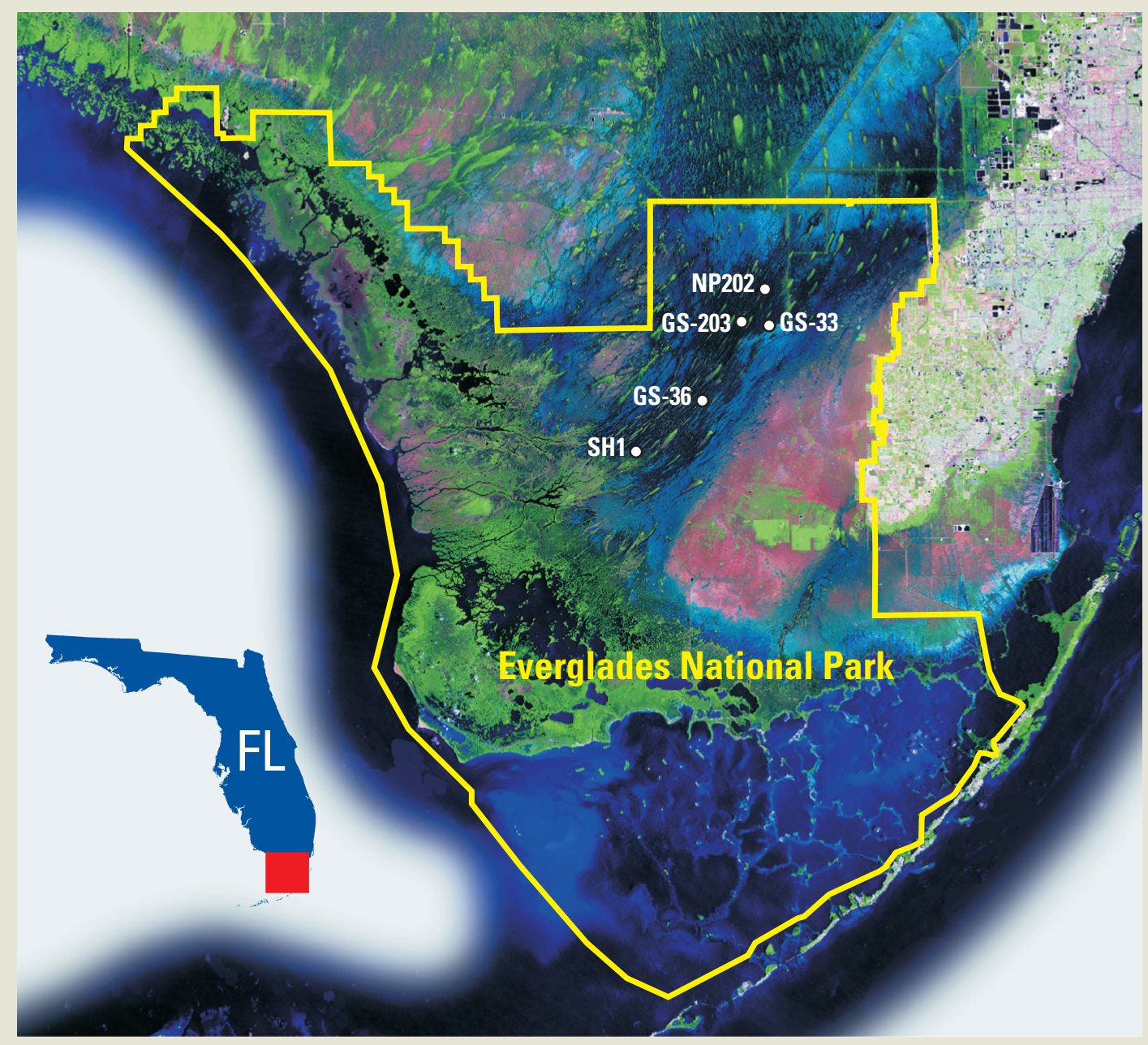

Open File Report 04-1233 


\section{Flow Velocity, Water Temperature, and Conductivity in Shark River Slough, Everglades National Park, Florida: June 2002-July 2003}

By Ami L. Riscassi and Raymond W. Schaffranek

Open File Report 2004-1233 


\title{
U.S. Department of the Interior \\ Gale A. Norton, Secretary
}

\section{U.S. Geological Survey \\ Charles G. Groat, Director}

U.S. Geological Survey, Reston, Virginia: 2004

\author{
For sale by U.S. Geological Survey, Information Services \\ Box 25286, Denver Federal Center \\ Denver, C0 80225 \\ For more information about the USGS and its products: \\ Telephone: 1-888-ASK-USGS \\ World Wide Web: http://www.usgs.gov/
}

\footnotetext{
Any use of trade, product, or firm names in this publication is for descriptive purposes only and does not imply endorsement by the U.S. Government.

Although this report is in the public domain, permission must be secured from the individual copyright owners to reproduce any copyrighted materials contained within this report.
} 


\section{Contents}

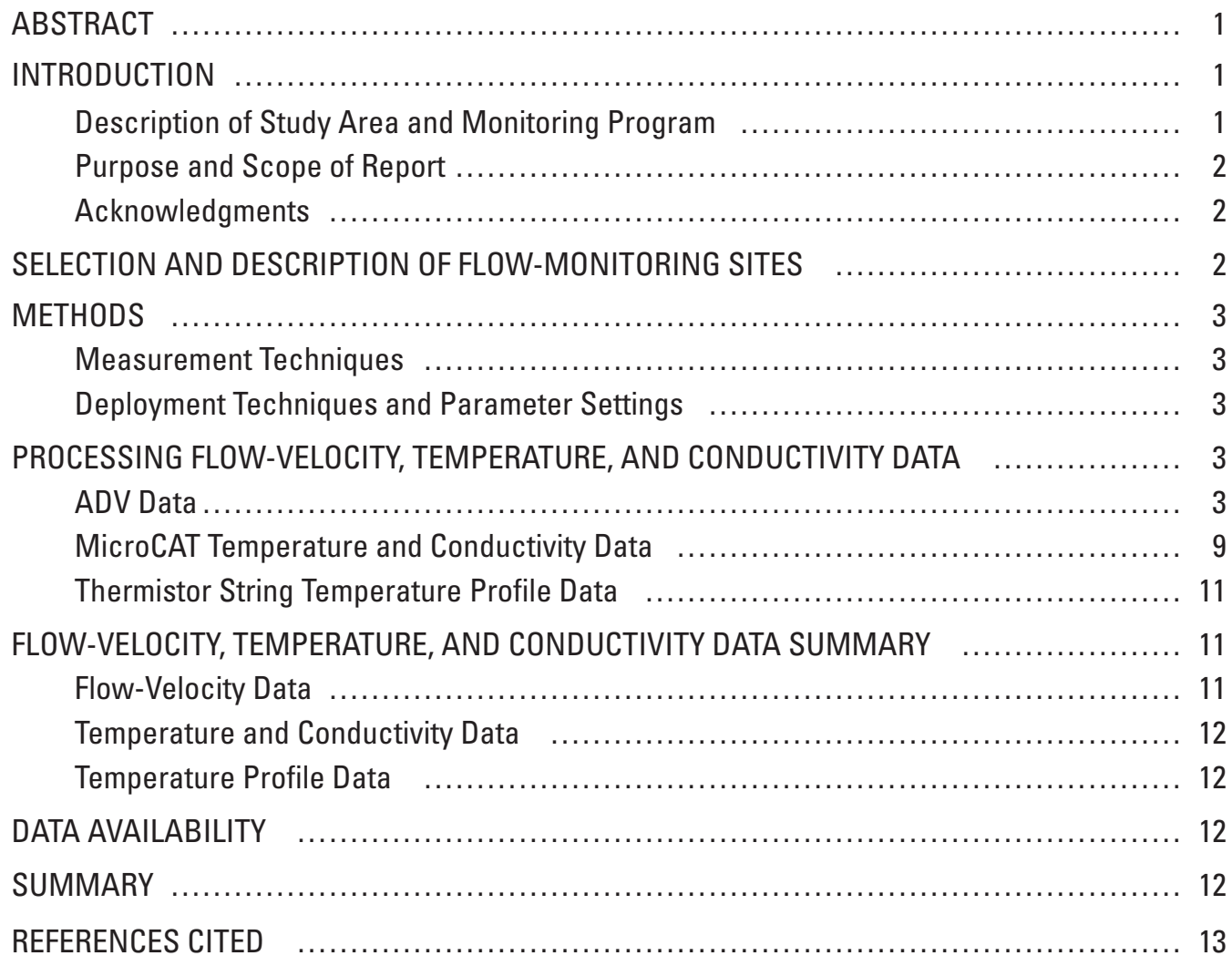

APPENDIX A. Daily mean flow velocities and water depths at station SH1 during the 2002-2003 wet season

APPENDIX B. Daily mean flow velocities, water temperatures, specific conductances, and water depths at station GS-203 during the 2002-2003 wet season.

APPENDIX C. Daily mean flow velocities, water temperatures, specific conductances, and water depths at station GS-33 during the 2002-2003 wet season.

APPENDIX D. Daily mean flow velocities, water temperatures, specific conductances, and water depths at station GS-36 during the 2002-2003 wet season. 


\section{Figures}

1. Satellite image of south Florida showing locations of monitoring stations SH1, GS-203, GS-33, GS-36, and NP202 in Everglades National Park $\ldots \ldots \ldots \ldots \ldots \ldots \ldots . . \ldots 2$

2. ADV unit deployed in a sparse spikerush area at GS-36 f......................... 3

3. Conductivities measured continuously by MicroCAT probe and intermittently by hand-held YSI meter at GS-203 in Shark River Slough, Everglades National Park, during the 2002-2003 wet season

4. Conductivities measured continuously by MicroCAT probe and intermittently by hand-held YSI meter at GS-33 in Shark River Slough, Everglades National Park, during the 2002-2003 wet season.

5. Conductivities measured continuously by MicroCAT probe and intermittently by hand-held YSI meter at GS-36 in Shark River Slough,

Everglades National Park, during the 2002-2003 wet season

6. Burst-averaged flow velocities, shown as vectors relative to magnetic north, at SH1 in Shark River Sough, Everglades National Park, during the 2002-2003 wet season

7. Burst-averaged flow velocities, shown as vectors relative to magnetic north, at GS-203 in Shark River Slough, Everglades National Park, during the 2002-2003 wet season

8. Burst-averaged flow velocities, shown as vectors relative to magnetic north, at GS-33 in Shark River Slough, Everglades National Park, during the 2002-2003 wet season

9. Burst-averaged flow velocities, shown as vectors relative to magnetic north, at GS-36 in Shark River Slough, Everglades National Park, during the 2002-2003 wet season

\section{Tables}

1. Site locations and instrumentation for flow-velocity and water-temperature monitoring stations

2. Deployment parameter settings for SH1, GS-203, GS-33, and GS-36 ADV units

3. Deployment specifications and parameter settings for SH1, GS-203, GS-33, GS-36, and NP202 thermistor strings.

4. ADV data-collection summaries for SH1, GS-203, GS-33, and GS-36.

5. Post-processing changes to ADV deployment parameter settings for $\mathrm{SH} 1$, GS-203, GS-33, and GS-36 


\section{Appendixes}

A. Tables A-1-A-2. Daily mean flow velocities and water depths at station SH1, during the 2002-2003 wet season.

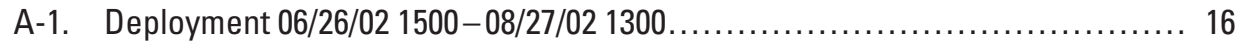

A-2. Deployment 08/28/02 1029-09/25/02 0859.......................... 18

B. Tables B-1-B-5. Daily mean flow velocities, water temperatures, specific conductances, and water depths at station GS-203 during the 2002-2003 wet season.

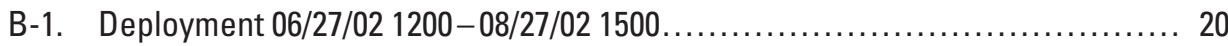

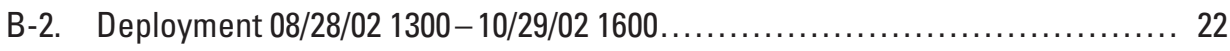

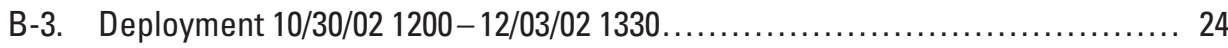

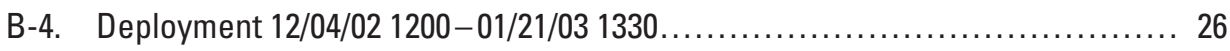

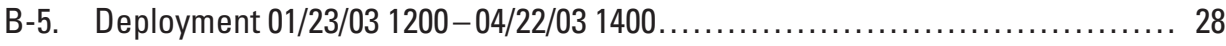

C. Tables C-1-C-5. Daily mean flow velocities, water temperatures, specific conductances, and water depths at station GS-33 during the 2002-2003 wet season.

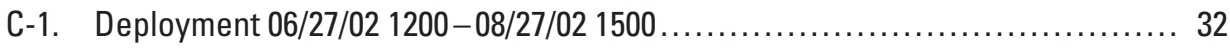

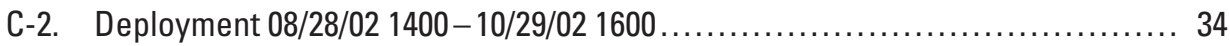

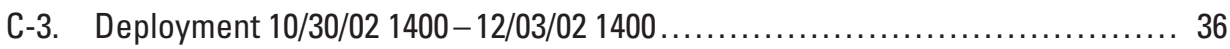

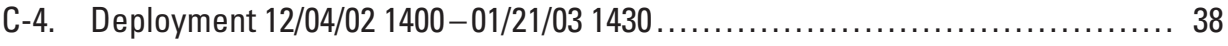

C-5. Deployment 01/22/03 1100-04/15/03 1730 .............................. 40

D. Tables D-1-D-6. Daily mean flow velocities, water temperatures, specific conductances, and water depths at station GS-36 during the 2002-2003 wet season.

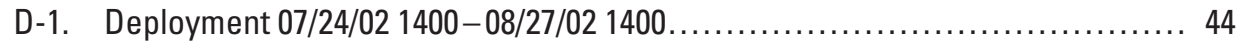

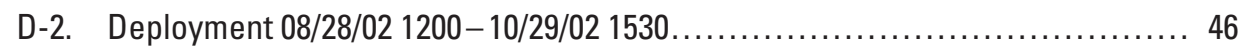

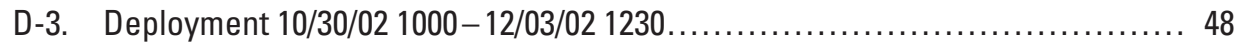

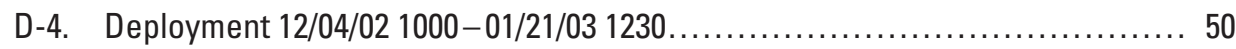

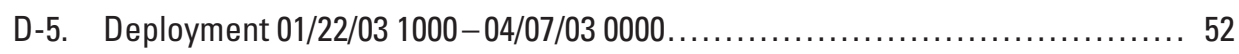

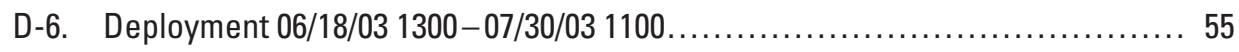




\section{Conversion Factors, Abbreviations, and Horizontal Datum}

\begin{tabular}{lcl}
\hline Divide & By & To obtain \\
\hline & Length & \\
\hline millimeter $(\mathrm{mm})$ & 25.4 & inch (in.) \\
centimeter $(\mathrm{cm})$ & 2.54 & inch (in.) \\
meter $(\mathrm{m})$ & 0.3048 & foot $(\mathrm{ft})$ \\
kilometer $(\mathrm{km})$ & 1.609 & mile $(\mathrm{mi})$ \\
\hline & Velocity & \\
\hline centimeter per second $(\mathrm{cm} / \mathrm{s})$ & 30.48 & foot per second $(\mathrm{ft} / \mathrm{s})$ \\
\hline
\end{tabular}

Temperature in degrees Celsius $\left({ }^{\circ} \mathrm{C}\right)$ can be converted to degrees Fahrenheit ( $\left.{ }^{\circ} \mathrm{F}\right)$ as:

$$
{ }^{\circ} \mathrm{F}=\left(1.8 \times{ }^{\circ} \mathrm{C}\right)+32
$$

Direction of flow is reported in degrees clockwise from magnetic north ( ${ }^{\circ} \mathrm{CW}$ from MN).

Frequency of velocity measurements is reported in hertz $(\mathrm{Hz})$.

Salinity is reported in parts per thousand (ppt).

Signal-to-noise ratio is reported in decibels $(\mathrm{dB})$.

Specific conductance is reported in microsiemens per centimeter $(\mu \mathrm{S} / \mathrm{cm})$ at 25 degrees Celsius. Horizontal coordinates are referenced to North American Datum of 1983 (NAD83). 


\title{
Flow Velocity, Water Temperature, and Conductivity in Shark River Slough, Everglades National Park, Florida: June 2002 - July 2003
}

\author{
Ami L. Riscassi and Raymond W. Schaffranek
}

\section{ABSTRACT}

The data described in this report were collected in the U. S. Geological Survey (USGS) Priority Ecosystems Science project investigating "Forcing Effects on Flow Structure in Vegetated Wetlands of the Everglades." Data collected at five locations in Shark River Slough, Everglades National Park, during the 2002-2003 wet season are documented in the report. Methods used to process the data are described. Daily mean flow velocities, water temperatures, and specific conductance values are presented in the appendices. The quality-checked and edited data have been compiled and stored on the USGS South Florida Information Access (SOFIA) website $h t t p: / / s o f i a$. usgs.gov.

\section{INTRODUCTION}

A major thrust of the Everglades restoration effort, according to the Comprehensive Everglades Restoration Plan available on the website $h t t p: / / w w w . e v e r g l a d e s p l a n$. org, is to restore the natural functioning of the ecosystem to pre-drainage conditions. This objective requires detailed knowledge of the hydrologic and hydraulic factors that affect the natural flow of water through the Everglades wetlands. The heterogeneous vegetation, small topographic gradient, microtopography, and ridgeand-slough structure of the landscape variously affect flows through the vast mosaic of sloughs, marshes, and wet prairies that make up the Everglades. Data collected in this project document the temporal and spatial variability of the extremely low flow velocity of the shallow water in the heterogeneous wetlands and provide insight into the hydrologic processes and hydraulic factors that affect its flow through the low-gradient landscape.
Shark River Slough is the dominant pathway for surface-water flow in Everglades National Park (ENP) (fig. 1). It serves as the primary conduit for freshwater inflows discharged through culverts and hydraulic control structures along Tamiami Trail to the coastal mangrove ecotone of the southwest Gulf Coast of Florida. Flow-velocity, water-temperature, and conductivity data collected in Shark River Slough during June 2002 through July 2003 (2002-2003 wet season) are presented in this report. Data collected in the 2002-2003 wet season represent the final data-collection effort for the project. These data supplement data collected during the 1999-2000, 2000-2001, and 2001-2002 wet seasons documented previously (Riscassi and Schaffranek, 2002, 2003).

\section{Description of Study Area and Monitoring Program}

The freshwater wetlands of Shark River Slough are a mixture of tree islands, sawgrass marshes, wet prairies, and sloughs that variously affect the conveyance of water to the coastal mangrove ecotone. Flow velocities and (or) related hydrologic parameters were monitored at five sites (SH1, GS-203, GS-33, GS-36, and NP202) with differing vegetative characteristics (fig. 1 and Table 1). At all five sites, temperatures were monitored in the plant litter, throughout the water column, on the water surface, and in the air above the water column using thermistors (thermally sensitive resistors). At four of the sites (SH1, GS-203, GS-33, and GS-36), flow velocities were monitored at a fixed point in the water column using acoustic Doppler velocity (ADV) meters. At three of the four ADV monitoring sites (GS-203, GS-33, and GS-36), water temperatures and conductivities were monitored at a fixed point in the water column using water-quality probes. 


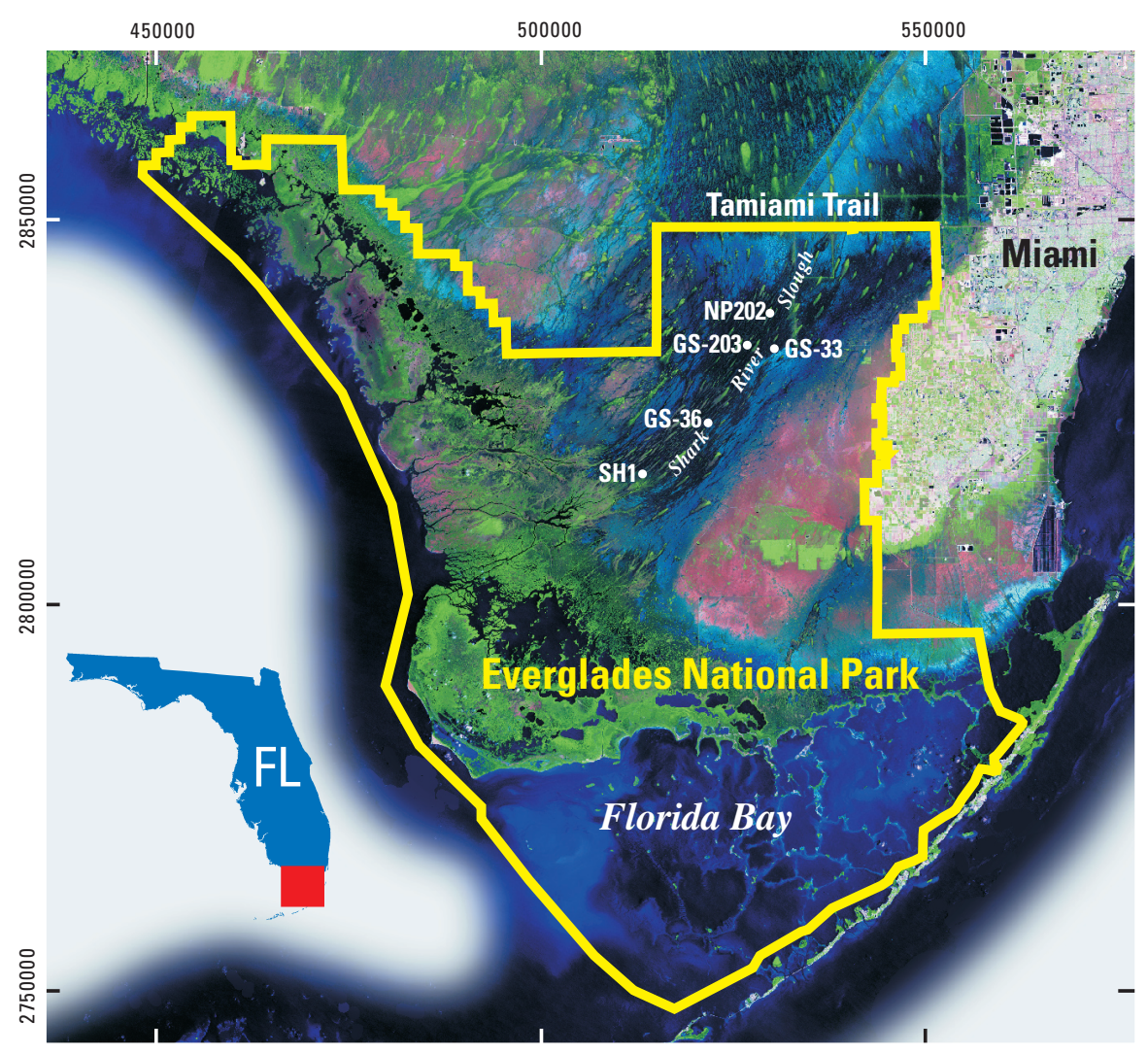

Base from U.S. Geological Survey South Florida satellite image map, 1993 Universal Transverse Metcator, NAD 83, Zone 17 Meters

Figure 1. Satellite image of south Florida showing locations of monitoring stations SH1, GS-203, GS-33, GS-36, and NP202 in Everglades National Park, 1:500,000 scale.

\section{Purpose and Scope of Report}

The flow-velocity, water-temperature, and conductivity data collected in the 2002-2003 wet season, as processed and presented in this report, are intended to supplement the data documented in Riscassi and Schaffranek $(2002,2003)$ for the 1999-2002 wet seasons. This report identifies the deployment and parameter specifications, describes the data-processing techniques, and presents the flow-velocity and related hydrologic data collected at five monitoring sites during the 2002-2003 wet season. Daily mean flow velocities and directions, specific conductances, and water temperatures are listed in the report appendixes. Quality checked and edited data are available for downloading from the Data Exchange page of the USGS SOFIA website http://sofia.usgs.gov.

\section{Acknowledgments}

Gordon Anderson, USGS, provided ancillary stage data from the SH1 hydrologic monitoring station. Kevin Kotun, National Park Service (NPS)/ENP, provided ancillary stage data from the NP203, NP202, P33, and P36 hydrologic monitoring stations. Edward German and Sandra Kinnaman, both of USGS, provided meteorological data from the P33 and SH1 evapotranspiration stations for flow analyses. Edward Simonds, USGS, provided logistical and technical support. Michael Duff, formerly of the USGS, developed the ADV filtering and plotting programs used to process, analyze, and display the flow-velocity data.

\section{SELECTION AND DESCRIPTION OF FLOW-MONITORING SITES}

Locations of the flow-velocity and water-temperature monitoring stations SH1, GS-203, GS-33, GS-36, and NP202 are shown in figure 1 . Thermistor strings were deployed at all five sites. ADV units were deployed at SH1, GS-203, GS-33, and GS-36. The ADV units at GS-203, GS-33, and GS-36 were equipped with integrated MicroCAT conductivity/temperature probes. 
Sites SH1, GS-203, GS-33, and NP202 were established in differing vegetative communities as documented in Table 1 and previously described in Riscassi and Schaffranek (2002, 2003). In July 2002, an ADV unit and thermistor string were deployed at site GS-36 (fig. 2) to monitor flow velocities, conductivities, and temperature profiles in an area of sparse spikerush approximately midway between established flow-monitoring stations SH1 and GS-33. The GS-36 site was located near the NPS P36 hydrologic monitoring station to provide water-level data for flow analyses. Monitoring site locations, types of instrumentation deployed, and vegetative characteristics during the 2002-2003 wet seasons are identified in table 1.

\section{METHODS}

Methods developed to measure the flow velocity, water temperature, and conductivity are identical to those defined in Riscassi and Schaffranek (2002). A brief description of the measurement techniques and a summary of the deployment techniques and critical parameter settings for the 2002-2003 wet season are provided in this section of the report.

\section{Measurement Techniques}

Flow velocities were measured bi-hourly at a fixed point in the water column using SonTek/YSI $10 \mathrm{MHz}$ ADVField units (Sontek, 2001). Conductivity and temperature data were measured bi-hourly near the top of the litter layer using MicroCAT model SBE 37-SI meters developed by Sea-Bird Electronics (Sea-Bird Electronics, 1999). Temperatures were measured at 15-minute intervals in the plant litter, typically at 5- or 10-cm-depth increments throughout the water column, on the water surface, and in the air above the water surface using glass-encapsulated thermistors manufactured by Yellow Springs Instruments (YSI) (Yellow Springs Instruments, 1998). Thermistors at the GS-36 site were fixed at variable depth increments. Riscassi and Schaffranek (2002) present detailed descriptions of the instrumentation, including accuracy and resolution specifications.

\section{Deployment Techniques and Parameter Settings}

Deployment techniques and procedures used for the 2002-2003 wet season were the same as those documented in Riscassi and Schaffranek (2002) for the 1999-2001 wet seasons. ADV-deployment parameter settings at SH1, GS203, GS-33, and GS-36 are provided in table 2. Velocities were measured at $10-\mathrm{Hz}$ in a one minute burst yeilding 600 samples. MicroCAT meters were deployed 11, 17, and $15 \mathrm{~cm}$ above the plant-litter layer near the ADV meters at GS-203, GS-33, and GS-36, respectively. Thermistor positions, in relation to the top of the plant-litter layer, and temperature recording intervals at all monitoring sites are listed in table 3. The ADV meter recording interval and sample volume location, relative to the top of the plant-litter layer, are provided in table 4 for each deployment. Approximate water depths determined from water levels recorded at nearby hydrologic stations also are listed in table 4.

\section{PROCESSING FLOW-VELOCITY, TEMPERATURE, AND CONDUCTIVITY DATA}

In processing the flow-velocity, temperature, and conductivity data, factors such as instrument accuracies and environmental conditions associated with the wetland deployments were considered in the development of applicable processing techniques. Techniques and editing criteria used to process, quality check, and verify the data are summarized in the following report sections.

\section{ADV Data}

The techniques used to process ADV data collected during the 2002-2003 wet season are a continuation of methods developed and documented previously in Riscassi and Schaf-

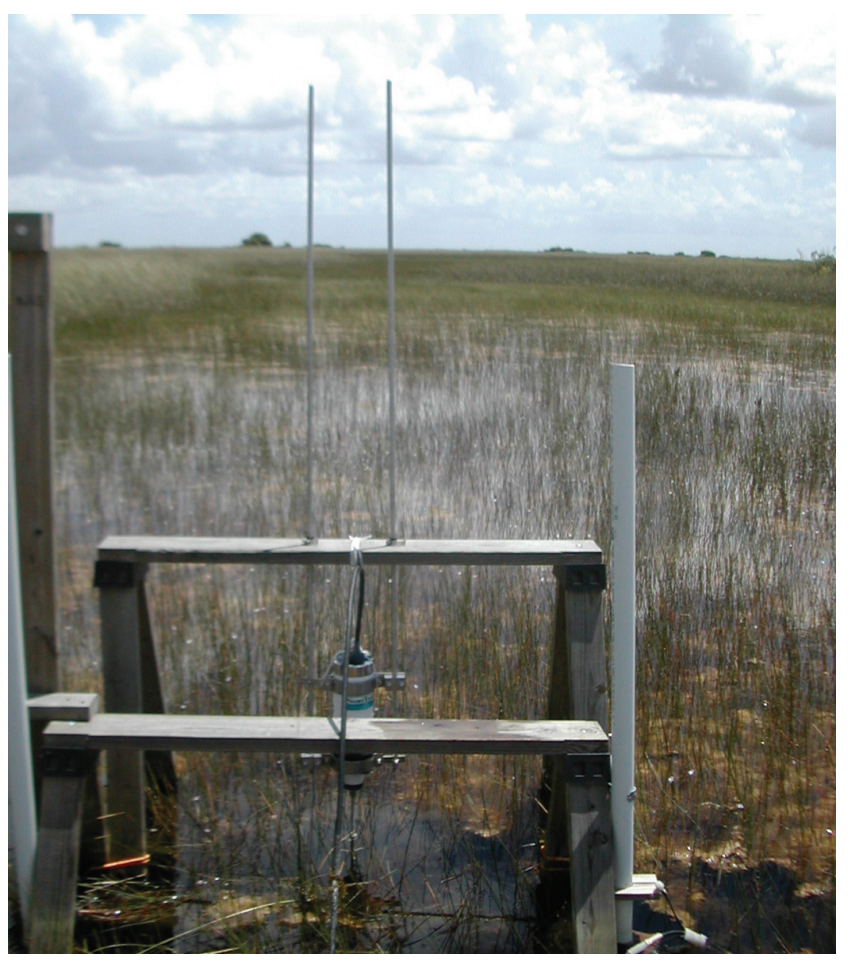

Figure 2. ADV probe deployed in a sparse spikerush area at GS-36. 
Table 1. Site locations and instrumentation for flow-velocity and water-temperature monitoring stations.

[UTM, Universal Transverse Mercator; NAD, North American Datum; m, meter; ADV, Acoustic Doppler Velocity]

\begin{tabular}{|c|c|c|c|c|c|}
\hline \multirow{2}{*}{$\begin{array}{l}\text { Site } \\
\text { Name }\end{array}$} & \multicolumn{2}{|c|}{$\begin{array}{l}\text { UTM Coordinates } \\
\text { NAD 83, Zone } 17\end{array}$} & \multirow{2}{*}{ Location } & \multirow{2}{*}{ Instrumentation } & \multirow{2}{*}{ Vegetation } \\
\hline & $\begin{array}{l}\text { East } \\
(\mathrm{m})\end{array}$ & $\begin{array}{c}\text { North } \\
(\mathrm{m})\end{array}$ & & & \\
\hline GS-203 & 526133 & 2833920 & $\begin{array}{l}160 \mathrm{~m} \text { from NP203 hydrologic station } \\
\text { at } 22.7 \text { degrees west of south }\end{array}$ & $\begin{array}{l}\text { ADV unit, MicroCAT meter, thermistor } \\
\text { string, data logger, solar panel }\end{array}$ & $\begin{array}{l}\text { medium-dense saw- } \\
\quad \text { grass }\end{array}$ \\
\hline GS-33 & 529637 & 2833457 & $\begin{array}{l}440 \text { m from P33 hydrologic station } \\
\text { at } 30.6 \text { degrees west of north }\end{array}$ & $\begin{array}{l}\text { ADV unit, MicroCAT meter, thermistor } \\
\text { string, data logger, solar panel }\end{array}$ & $\begin{array}{l}\text { medium-dense spike- } \\
\text { rush with periphyton }\end{array}$ \\
\hline SH1 & 515249 & 2817258 & $\begin{array}{l}10 \text { m southwest of SH1 hydrologic } \\
\text { station }\end{array}$ & $\begin{array}{l}\text { ADV unit, thermistor string, data logger, } \\
\text { solar panel }\end{array}$ & $\begin{array}{l}\text { medium-dense spike- } \\
\text { rush }\end{array}$ \\
\hline NP202 & 529245 & 2838450 & $\begin{array}{l}\text { co-located with NP202 hydrologic } \\
\text { station }\end{array}$ & $\begin{array}{l}\text { thermistor string, data logger, } \\
\text { solar panel }\end{array}$ & dense cattail \\
\hline GS-36 & 520563 & 2823605 & $\begin{array}{l}136 \text { m from P36 hydrologic station } \\
\text { at } 21 \text { degrees east of north }\end{array}$ & $\begin{array}{l}\text { ADV unit, MicroCAT meter, thermistor } \\
\text { string, data logger, solar panel }\end{array}$ & $\begin{array}{l}\text { sparse spikerush with } \\
\text { periphyton }\end{array}$ \\
\hline
\end{tabular}

franek (2002). A preliminary data-inspection process, a preediting data-conversion process, a quantitative data-editing process, and a qualitative inspection process were used to edit, verify, and otherwise process the recorded flow-velocity data. Specific deployment parameter settings used to collect the data and post-processing corrections applied to edit the data are identified in table 5 as old and new values, respectively.

Editing and filtering criteria used to process the ADV data for the 2002-2003 wet season include those suggested by the instrument manufacturer to detect suspect data attributed to poor signal quality (SonTek, 2001) and those developed during the processing and concurrent analysis of past ADV data (Ball and Schaffranek, 2000; Riscassi and Schaffranek, 2002, 2003). The equipment manufacturer suggests minimum signal-to-noise-ratio (SNR) and statistical-correlation values of $5 \mathrm{~dB}$ and 70 percent, respectively, as indicative of good acoustic signal quality (SonTek, 2001). Average SNR values determined from the filtered and processed data were approximately 5, 8, 11, and $4 \mathrm{~dB}$ at GS-203, GS-36, GS-33, and SH1, respectively, during all deployments. Lower SNR values at the SH1 site are directly related to the higher ambient noise of the specific ADV meter deployed there and are not indicative of poorer acoustic conditions, which are similar at all sites. Although SNR values were computed for each burst for all ADV deployments, they were not used as a quantitative automated data-editing criterion. Instead, they were used in conjunction with other hydrologic and meteorologic data in the qualitative editing processes as a means to evaluate the reliability of data that passed the quantitative filter criterion, but were deemed potentially erroneous or suspect in comparison to other flow velocities recorded during the deployment period.

Data that passed the preliminary data inspection process were first processed to correct for coordinate-system conversions and sound-speed re-calculations prior to quantitative automated data editing. The initial automated data-editing process consisted of the application of two filter criteria, one based on a minimal statistical correlation for each sample and the other on minimal number of valid samples per burst. A minimum correlation value of 70 percent was used as the statistical-filtering criterion. The minimum samples-per-burst criterion was determined by examination and assessment of plots of burst-averaged velocities generated using various minimum values of 600 , $500,400,300,200,100$, and 1 (1 meaning no minimum), in processing ADV data sets from the SH1, GS-203, GS-33, and GS-36 sites. As was determined in analyses of data collected during the 1999-2002 wet seasons, the 100-minimum filter criterion appeared too inclusive of suspect data and the 300-minimum criterion appeared overly exclusive of apparently valid data. Consequently, for the $10-\mathrm{Hz}$ one-minute burst sampling conducted at all four ADV sites, a criterion of 200 was determined to be the most appropriate minimum samples-per-burst filter and was subsequently used to process all ADV data sets. Differences between daily mean horizontal flow velocities computed using the most liberal criterion, one minimum sample, and all others $(100,200$, $300,400,500$, and 600) were found to be small in sensitivity tests conducted with past data (Riscassi and Schaffranek, 2002, 2003) and data documented in this report. (For the August through September 2002 deployments at SH1, GS-203, GS-33, and GS-36, the averages of the maximum 
Table 2. Deployment parameter settings for SH1, GS-203, GS-33, and GS-36 ADV units.

[min, minute; ${ }^{\circ} \mathrm{C}$, degrees Celsius; ppt, parts per thousand; cm/s, centimeter per second; EDT, Eastern Daylight Time; EST, Eastern Standard Time; ENU, geodetic East North Up]

\begin{tabular}{|c|c|c|c|c|c|}
\hline \multicolumn{6}{|c|}{ Deployment Parameters } \\
\hline Deployment Period $^{1}$ & $\begin{array}{c}\text { Recording } \\
\text { Interval } \\
\text { (min) }\end{array}$ & $\begin{array}{c}\text { Temperature } \\
\left({ }^{\circ} \mathrm{C}\right)\end{array}$ & $\begin{array}{l}\text { Salinity } \\
\text { (ppt) }\end{array}$ & $\begin{array}{c}\text { Velocity } \\
\text { Range } \\
\text { (cm/s) }\end{array}$ & $\begin{array}{c}\text { Coordinate } \\
\text { System }\end{array}$ \\
\hline \multicolumn{6}{|c|}{$\begin{array}{c}\text { SH1 } \\
\text { 2002-2003 Wet Season }\end{array}$} \\
\hline 06/26/02 1500-08/27/02 1300 EDT & 30 & 30 & 0.1 & $+/-10$ & ENU \\
\hline 08/28/02 1029-09/25/02 0859² EDT & 30 & 30 & 0.1 & $+/-10$ & ENU \\
\hline \multicolumn{6}{|c|}{$\begin{array}{c}\text { GS- } 203 \\
\text { 2002-2003 Wet Season }\end{array}$} \\
\hline 06/27/02 1200-08/27/02 1500 EDT & 30 & 29 & 0.0 & $+/-10$ & ENU \\
\hline 08/28/02 1300-10/29/02 1600 EDT & 30 & 29 & 0.0 & $+/-10$ & ENU \\
\hline 10/30/02 1200-12/03/02 1330 EDT & 30 & 29 & 0.0 & $+/-10$ & ENU \\
\hline 12/04/02 1200-01/21/03 1330 EST & 30 & 29 & 0.0 & $+/-10$ & ENU \\
\hline 01/23/03 1200-04/22/03 1400 EST & 30 & 20 & 0.1 & $+/-10$ & ENU \\
\hline \multicolumn{6}{|c|}{$\begin{array}{c}\text { GS-33 } \\
\text { 2002-2003 Wet Season }\end{array}$} \\
\hline 06/27/02 1200-08/27/02 1500 EDT & 30 & 28 & 0.1 & $+/-10$ & ENU \\
\hline 08/28/02 1400-10/29/02 1600 EDT & 30 & 29 & 0.1 & $+/-10$ & ENU \\
\hline 10/30/02 1400-12/03/02 1400 EDT & 30 & 29 & 0.1 & $+/-10$ & ENU \\
\hline 12/04/02 1400-01/21/03 1430 EST & 30 & 29 & 0.1 & $+/-10$ & ENU \\
\hline 01/22/03 1100-04/15/03 2130 EST & 30 & 20 & 0.1 & $+/-10$ & ENU \\
\hline \multicolumn{6}{|c|}{$\begin{array}{c}\text { GS-36 } \\
\text { 2002-2003 Wet Season }\end{array}$} \\
\hline 07/24/02 1400-08/27/02 1400 EDT & 30 & 30 & 0.1 & $+/-10$ & ENU \\
\hline 08/28/02 1200-10/29/02 1530 EDT & 30 & 30 & 0.1 & $+/-10$ & ENU \\
\hline 10/30/02 1000-12/03/02 1230 EDT & 30 & 30 & 0.1 & $+/-10$ & ENU \\
\hline 12/04/02 1000-01/21/03 1230 EST & 30 & 20 & 0.1 & $+/-10$ & ENU \\
\hline 01/22/03 1000-04/07/03 0000 EST & 30 & 20 & 0.1 & $+/-10$ & ENU \\
\hline 06/18/03 1300-07/30/03 1100 EST & 30 & 29 & 0.1 & $+/-10$ & ENU \\
\hline
\end{tabular}

${ }^{1}$ Excludes any invalid data segments at beginning and end of deployment record.

${ }^{2}$ Data collection inadvertently initiated at non-multiple time interval.

daily-mean velocity differences using all seven samples-perburst filters were $0.12,0.05,0.01$, and $0.01 \mathrm{~cm} / \mathrm{s}$, with the largest maximum differences for daily-mean values being $0.66,0.16,0.04$, and $0.35 \mathrm{~cm} / \mathrm{s}$, respectively.)

A secondary qualitative processing technique included the generation of plots of filtered data to detect any remaining anomalous horizontal flow speeds and directions, likely due to various environmental factors such as vegetation getting caught on the probe, floating into the path of acoustic signal, or causing variable backscatter influences. The quali- tative inspection resulted in the removal of 15 percent of velocity bursts from all deployments at SH1, which included a 9-day period. For all deployments at GS-203, 16 percent of velocity bursts were removed, which included 22- and 14-day periods. For all deployments at GS-33, 23 percent of the velocity bursts were removed in the qualitative analyses, which included a 2-month period at the end of the deployment. For all valid deployments at GS-36, 20 percent of the velocity bursts were removed in the qualitative analyses, which included a 2-month period at the end of the deploy- 
Table 3. Deployment specifications and parameter settings for SH1, GS-203, GS-33, GS-36, and NP202 thermistor strings. [min, minute; cm, centimeter; EDT, Eastern Daylight Time; EST, Eastern Standard Time]

\begin{tabular}{|c|c|c|}
\hline Deployment Period & $\begin{array}{l}\text { Recording Interval } \\
\text { (min) }\end{array}$ & $\begin{array}{l}\text { Thermistor Height }{ }^{1} \\
\text { (cm) }\end{array}$ \\
\hline \multicolumn{3}{|c|}{$\begin{array}{c}\text { SH1 } \\
\text { 2002-2003 Wet Season }\end{array}$} \\
\hline 07/25/02 0845-08/27/02 1330 EDT & 15 & $0,10,20,30,40,50,60,70,80,90,110$ \\
\hline 08/27/02 1345-09/25/02 0930 EDT & 15 & $0,10,20,30,40,50,60,70,80,90,110$ \\
\hline \multicolumn{3}{|c|}{$\begin{array}{c}\text { GS-203 } \\
\text { 2002-2003 Wet Season }\end{array}$} \\
\hline 06/27/02 0900-08/28/02 0900 EDT & 15 & $0,10,20,25,30,35,40,45,55,65$, water surface ${ }^{2}$ \\
\hline 08/28/02 0915-09/24/02 0815 EDT & 15 & $0,10,20,25,30,35,40,45,55,65$, water surface ${ }^{2}$ \\
\hline 09/24/02 0830-12/03/02 1330 EDT & 15 & $0,10,20,25,30,35,40,45,55,65$, water surface ${ }^{2}$ \\
\hline 12/03/02 1345-01/21/03 1345 EST & 15 & $0,10,20,25,30,35,40,45,55,65$, water surface ${ }^{2}$ \\
\hline 01/21/03 1400-06/16/03 0945 EST & 15 & $0,10,20,25,30,35,40,45,55,65$, water surface ${ }^{2}$ \\
\hline \multicolumn{3}{|c|}{$\begin{array}{c}\text { GS-33 } \\
\text { 2002-2003 Wet Season }\end{array}$} \\
\hline 06/27/02 1130-07/25/02 0845 EDT & 15 & $0,10,20,25,30,35,40,45,55,65$, water surface ${ }^{2}$ \\
\hline 07/25/02 0900-08/27/02 1515 EDT & 15 & $0,10,20,25,30,35,40,45,55,65$, water surface ${ }^{3}$ \\
\hline 08/29/02 1530-09/24/02 1315 EDT & 15 & $0,10,20,25,30,35,40,45,55,65$, water surface ${ }^{3}$ \\
\hline 09/24/02 1330-10/30/02 1400 EDT & 15 & $0,10,20,25,30,35,40,45,55,65$, water surface ${ }^{3}$ \\
\hline 10/30/02 1315-12/03/02 1415 EST & 15 & $0,10,20,25,30,35,40,45,55,65$, water surface ${ }^{3}$ \\
\hline 12/03/02 1430-01/21/03 1445 EST & 15 & $0,10,20,25,30,35,40,45,55,65$, water surface ${ }^{3}$ \\
\hline 01/21/03 1500-06/16/03 0715 EST & 15 & $0,10,20,25,30,35,40,45,55,65$, water surface ${ }^{3}$ \\
\hline \multicolumn{3}{|c|}{$\begin{array}{c}\text { NP202 } \\
\text { 2002-2003 Wet Season }\end{array}$} \\
\hline 06/27/02 1415-09/24/02 1300 EDT & 15 & $0,10,20,30,40,50,60,70,80,90$, water surface ${ }^{2}$ \\
\hline 09/24/02 1315-10/30/02 1315 EDT & 15 & $0,10,20,30,40,50,60,70,80,90$, water surface ${ }^{2}$ \\
\hline 10/30/02 1330-12/04/02 1215 EST & 15 & $0,10,20,30,40,50,60,70,80,90$, water surface ${ }^{2}$ \\
\hline 12/04/02 1230-01/21/03 1415 EST & 15 & $0,10,20,30,40,50,60,70,80,90$, water surface ${ }^{2}$ \\
\hline 01/21/03 1430-06/16/03 1045 EST & 15 & $0,10,20,30,40,50,60,70,80,90$, water surface ${ }^{2}$ \\
\hline \multicolumn{3}{|c|}{$\begin{array}{c}\text { GS-36 } \\
\text { 2002-2003 Wet Season }\end{array}$} \\
\hline 07/25/02 0930-08/07/02 1900 EDT & 15 & $-7,0,7,12,19,20,24,27,29,46$, water surface ${ }^{2}$ \\
\hline 08/27/02 1930-09/17/02 1330 EDT & 15 & $-7,0,7,12,19,20,24,27,29,46$, water surface ${ }^{2}$ \\
\hline 09/17/02 1400-09/24/02 1015 EDT & 15 & $-7,0,7,12,19,20,24,27,29,46$, water surface ${ }^{2}$ \\
\hline 09/24/02 1045-10/30/02 1000 EDT & 15 & $-7,0,7,12,19,20,24,27,29,46$, water surface ${ }^{2}$ \\
\hline 10/30/02 1015-12/03/02 1245 EST & 15 & $-7,0,7,12,19,20,24,27,29,46$, water surface ${ }^{2}$ \\
\hline 12/03/02 1315-01/21/03 1245 EST & 15 & $-7,0,7,12,19,20,24,27,29,46$, water surface ${ }^{2}$ \\
\hline 01/21/03 1300-06/16/03 0815 EST & 15 & $-7,0,7,12,19,20,24,27,29,46$, water surface ${ }^{2}$ \\
\hline 06/16/03 0930-07/30/03 1145 EDT & 15 & $-7,0,7,12,19,20,24,27,29,46$, water surface ${ }^{2}$ \\
\hline
\end{tabular}

${ }^{1}$ Measured from 1-2 cm below top of plant-litter layer.

${ }^{2}$ Thermistor measuring water-surface temperature is subject to being suspended in air or submerged by vegetation.

${ }^{3}$ No data recorded for thermistor during entire deployment due to communications failure. 
Table 4. ADV data-collection summaries for SH1, GS-203, GS-33, and GS-36.

[min, minute; cm, centimeter; avg, average; EDT, Eastern Daylight Time; EST, Eastern Standard Time]

\begin{tabular}{|c|c|c|c|}
\hline Deployment Period ${ }^{1}$ & $\begin{array}{l}\text { Recording } \\
\text { Interval } \\
\text { (min) }\end{array}$ & $\begin{array}{l}\text { Sample Volume Location } \\
\text { Above Top of Litter } \\
\text { (cm) }\end{array}$ & $\begin{array}{l}\text { Approximate Water } \\
\text { Depth Range (avg) } \\
\text { (cm) }\end{array}$ \\
\hline \multicolumn{4}{|c|}{$\begin{array}{c}\text { SH1 } \\
\text { 2002-2003 Wet Season }\end{array}$} \\
\hline 06/26/02 1500-08/27/02 1300 EDT & 30 & 34 & $42-67(52)$ \\
\hline 08/28/02 1029-09/25/02 0859² EDT & 30 & 34 & $50-57(54)$ \\
\hline \multicolumn{4}{|c|}{$\begin{array}{c}\text { GS-203 } \\
\text { 2002-2003 Wet Season }\end{array}$} \\
\hline 06/27/02 1200-08/27/02 1500 EDT & 30 & 19 & $36-51(45)$ \\
\hline 08/28/02 1300-10/29/02 1600 EDT & 30 & 19 & $51-57(53)$ \\
\hline 10/30/02 1200-12/03/02 1330 EDT & 30 & 19 & $40-53(47)$ \\
\hline 12/04/02 1200-01/21/03 1330 EST & 30 & 15 & $27-40(34)$ \\
\hline 01/23/03 1200-04/22/03 1400 EST & 30 & 15 & $19-28(23)$ \\
\hline \multicolumn{4}{|c|}{$\begin{array}{c}\text { GS-33 } \\
\text { 2002-2003 Wet Season }\end{array}$} \\
\hline 06/27/02 1200-08/27/02 1500 EDT & 30 & 19 & $33-45(39)$ \\
\hline 08/28/02 1400-10/29/02 1600 EDT & 30 & 19 & $44-50(47)$ \\
\hline 10/30/02 1400-12/03/02 1400 EDT & 30 & 19 & $35-47(41)$ \\
\hline 12/04/02 1400-01/21/03 1430 EST & 30 & 9 & $26-40(32)$ \\
\hline 01/22/03 1100-04/15/03 2130 EST & 30 & 9 & $17-48(26)$ \\
\hline \multicolumn{4}{|c|}{$\begin{array}{c}\text { GS-36 } \\
\text { 2002-2003 Wet Season }\end{array}$} \\
\hline 07/24/02 1400-08/27/02 1400 EDT & 30 & 20 & $31-40(35)$ \\
\hline 08/28/02 1200-10/29/02 1530 EDT & 30 & 20 & $40-44(42)$ \\
\hline 10/30/02 1000-12/03/02 1230 EDT & 30 & 20 & $34-41(37)$ \\
\hline 12/04/02 1000-01/21/03 1230 EST & 30 & 10 & $22-38(30)$ \\
\hline 01/22/03 1000-04/07/03 0000 EST & 30 & 10 & $13-22(16)$ \\
\hline 06/18/03 1300-07/30/03 1100 EST & 30 & 10 & $36-47(42)^{3}$ \\
\hline
\end{tabular}

${ }^{1}$ Excludes any invalid data segments at beginning and end of deployment record.

${ }^{2}$ Data collection inadvertently initiated at non-multiple time interval.

${ }^{3}$ No data available from P36 stage recorder, values are based on 2 measurements taken during site visits. 
Table 5. Post-processing changes to deployment parameter settings for SH1, GS-203, GS-33, and GS-36 ADV units.

[old, original setting; new, calculated correction; ${ }^{\circ} \mathrm{C}$, degrees Celsius; ppt, parts per thousand; EDT, Eastern Daylight Time; EST, Eastern Standard Time; ENU, geodetic East North Up].

\begin{tabular}{|c|c|c|c|c|c|c|}
\hline \multicolumn{7}{|c|}{ Parameter Settings } \\
\hline \multirow[b]{2}{*}{ Deployment Period ${ }^{1}$} & \multicolumn{2}{|c|}{ Temperature } & \multicolumn{2}{|c|}{ Salinity } & \multicolumn{2}{|c|}{ Coordinate System } \\
\hline & $\begin{array}{l}\text { Old } \\
\left({ }^{\circ} \mathrm{C}\right)\end{array}$ & $\begin{array}{l}\text { New } \\
\left({ }^{\circ} \mathrm{C}\right)\end{array}$ & $\begin{array}{l}\text { Old } \\
\text { (ppt) }\end{array}$ & $\begin{array}{l}\text { New } \\
\text { (ppt) }\end{array}$ & Old & New \\
\hline \multicolumn{7}{|c|}{$\begin{array}{c}\text { SH1 } \\
\text { 2002-2003 Wet Season }\end{array}$} \\
\hline 06/26/02 1500-08/27/02 1300 EDT & 30 & 31 & 0.1 & - & ENU & - \\
\hline 08/28/02 1029-09/25/02 0859² EDT & 30 & 30 & 0.1 & - & ENU & - \\
\hline \multicolumn{7}{|c|}{$\begin{array}{c}\text { GS- } 203 \\
\text { 2002-2003 Wet Season }\end{array}$} \\
\hline 06/27/02 1200-08/27/02 1500 EDT & 29 & 31 & 0.0 & 0.18 & ENU & - \\
\hline 08/28/02 1300-10/29/02 1600 EDT & 29 & 29 & 0.0 & 0.20 & ENU & - \\
\hline 10/30/02 1200-12/03/02 1330 EDT & 29 & 23 & 0.0 & 0.22 & ENU & - \\
\hline 12/04/02 1200-01/21/03 1330 EST & 29 & 23 & 0.0 & 0.24 & ENU & - \\
\hline 01/23/03 1200-04/22/03 1400 EST & 20 & 22 & 0.1 & 0.26 & ENU & - \\
\hline \multicolumn{7}{|c|}{$\begin{array}{c}\text { GS-33 } \\
\text { 2002-2003 Wet Season }\end{array}$} \\
\hline 06/27/02 1200-08/27/02 1500 EDT & 28 & 30 & 0.1 & 0.19 & ENU & - \\
\hline 08/28/02 1400-10/29/02 1600 EDT & 29 & 29 & 0.1 & 0.24 & ENU & - \\
\hline 10/30/02 1400-12/03/02 1400 EDT & 29 & 23 & 0.1 & 0.26 & ENU & - \\
\hline 12/04/02 1400-01/21/03 1430 EST & 29 & 18 & 0.1 & 0.27 & ENU & - \\
\hline 01/22/03 1100-04/15/03 2130 EST & 20 & 23 & 0.1 & 0.25 & ENU & - \\
\hline \multicolumn{7}{|c|}{$\begin{array}{c}\text { GS-36 } \\
\text { 2002-2003 Wet Season }\end{array}$} \\
\hline 07/24/02 1400-08/27/02 1400 EDT & 30 & 32 & 0.1 & 0.17 & ENU & - \\
\hline 08/28/02 1200-10/29/02 1530 EDT & 30 & 30 & 0.1 & 0.21 & ENU & - \\
\hline 10/30/02 1000-12/03/02 1230 EDT & 30 & 24 & 0.1 & 0.22 & ENU & - \\
\hline 12/04/02 1000-01/21/03 1230 EST & 20 & 19 & 0.1 & 0.25 & ENU & - \\
\hline 01/22/03 1000-04/07/03 0000 EST & 20 & 24 & 0.1 & $0.23^{3}$ & ENU & - \\
\hline 06/18/03 1300-07/30/03 1100 EST & 29 & 30 & 0.1 & $0.20^{3}$ & ENU & - \\
\hline
\end{tabular}

${ }^{1}$ Excludes any invalid data segments at beginning and end of deployment record.

${ }^{2}$ Data collection inadvertently initiated at non-multiple time interval.

${ }^{3}$ MicroCAT communication failure, values approximated from previously recorded data. 
ment when water levels fell below the transducer of the ADV probe. Bursts that did not pass the qualitative inspection process were deleted and daily mean horizontal-flow speeds and directions were recalculated. The percentages of data that did not pass both the quantitative automated-filter and qualitative-analysis processes for each ADV deployment period are presented with daily mean flow summaries in tables in Appendixes A, B, C, and D. The subsequent removal of individual velocity bursts by qualitative analysis did not significantly change the resultant daily mean velocity magnitudes or flow directions.

\section{MicroCAT Temperature and Conductivity Data}

MicroCAT measured temperatures and conductivities at GS-36 were intermittently recorded from February 12 through March 25, 2003 (data recorded for 92 percent of the deployment period) and no data were recorded after March 25,2003 due to an equipment failure.

Temperatures, measured and recorded by the MicroCAT meter near the top of the plant-litter layer at the GS-203, GS-33, and GS-36 sites, were compared to temperatures measured by the thermistor of the temperature string that was approximately at the same depth in the water column as the MicroCAT meter. Good agreement was found between the two sets of data for all deployments. No anomalies were found in the MicroCAT temperature data. Daily mean temperatures, derived from data measured by the MicroCAT meters at GS-203, GS-33, and GS-36 are reported in Appendixes B, C, and D, respectively.

Conductivity data measured by the MicroCAT meter were compared to conductivity measurements taken with a hand-held portable YSI Model 30 meter during field visits. Good agreement was found between the YSI point measurements and MicroCAT data at GS-203, GS-33, and GS-36 (fig. 3, 4, and 5). At site GS-36, uncommonly low conductivity readings, which are indicative of a cellcontamination problem, were recorded from February 6, 2003 through the end of the deployment. All conductivity data recorded during that time period are erroneous. No anomalies were found in the remainder of the MicroCAT conductivity data.

Daily mean specific conductance values calculated from conductivities recorded at GS-203, GS-33, and GS36 are reported in Appendixes B, C, and D, respectively. Conductivity data are recorded in seimens per meter $(\mathrm{S} / \mathrm{m})$ and converted to specific conductance in microseimens per centimeter $(\mu \mathrm{S} / \mathrm{cm})$ at 25 degrees Celsius for reporting purposes as described in Riscassi and Schaffranek (2002).

GS-203

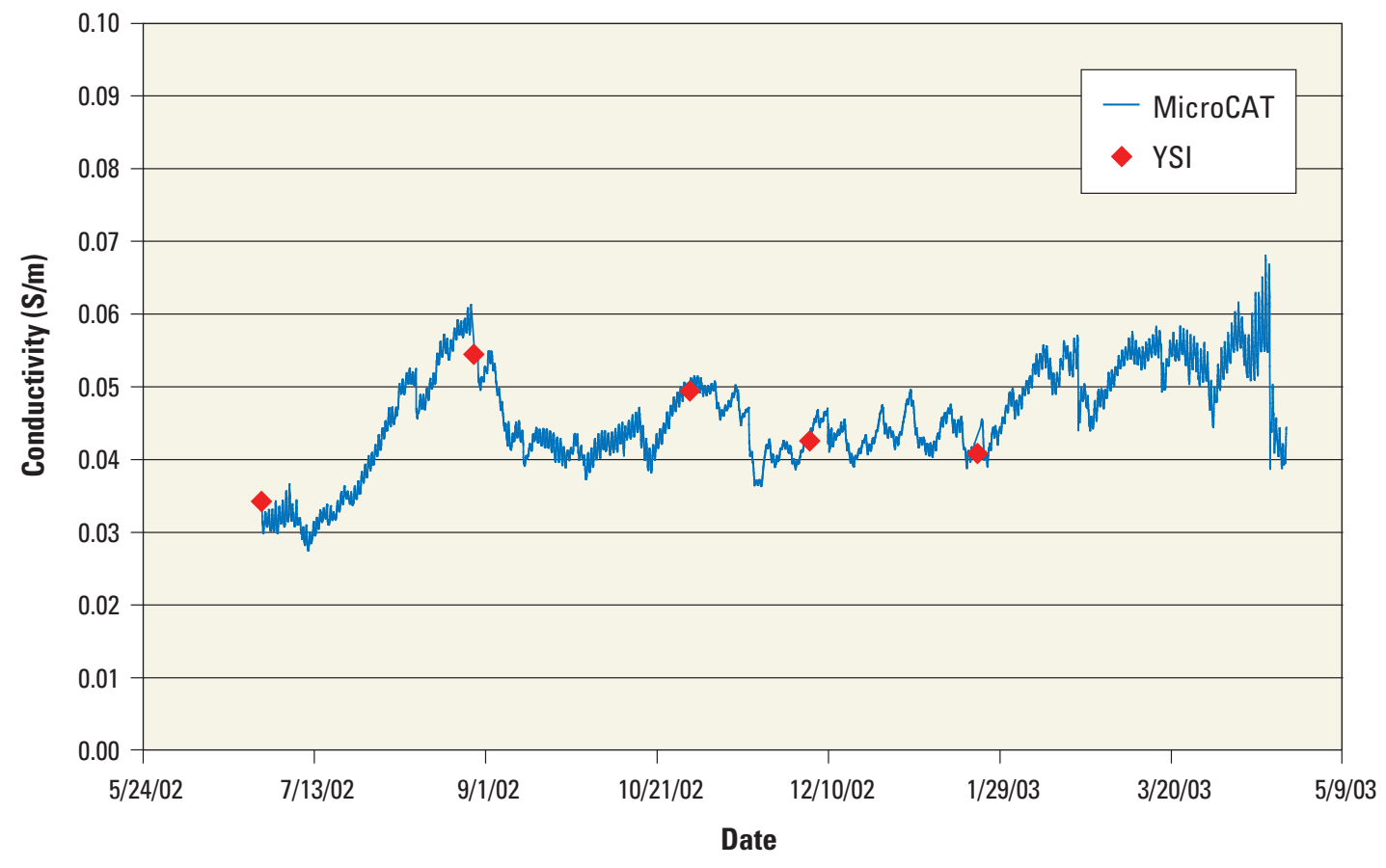

Figure 3. Conductivities measured continuously by MicroCAT probe and intermittently by hand-held YSI meter at GS-203 in Shark River Slough, Everglades National Park, during the 2002-2003 wet season. 


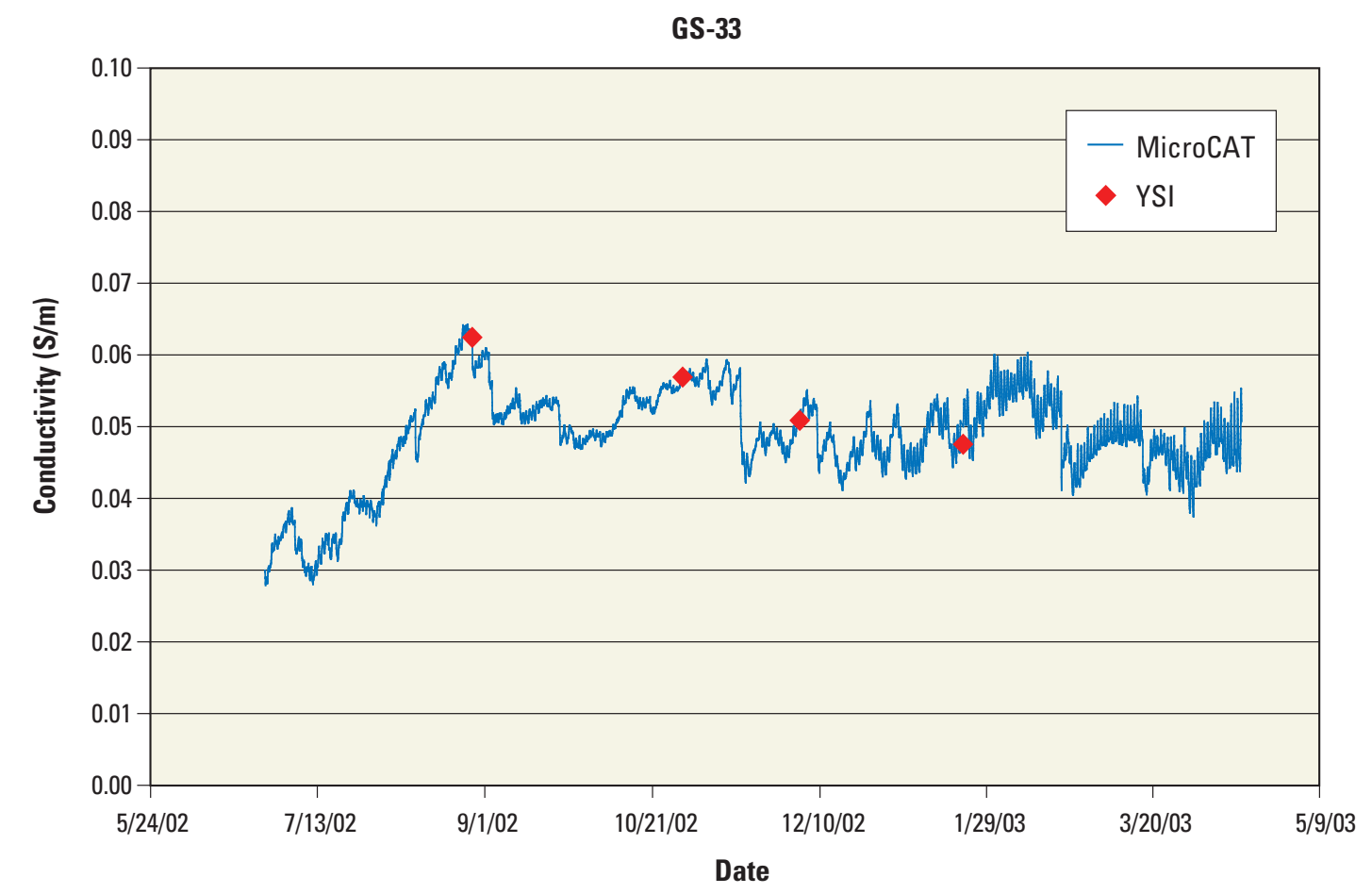

Figure 4. Conductivities measured continuously by MicroCAT probe and intermittently by hand-held YSI meter at GS-33 in Shark River Slough, Everglades National Park, during the 2002-2003 wet season.

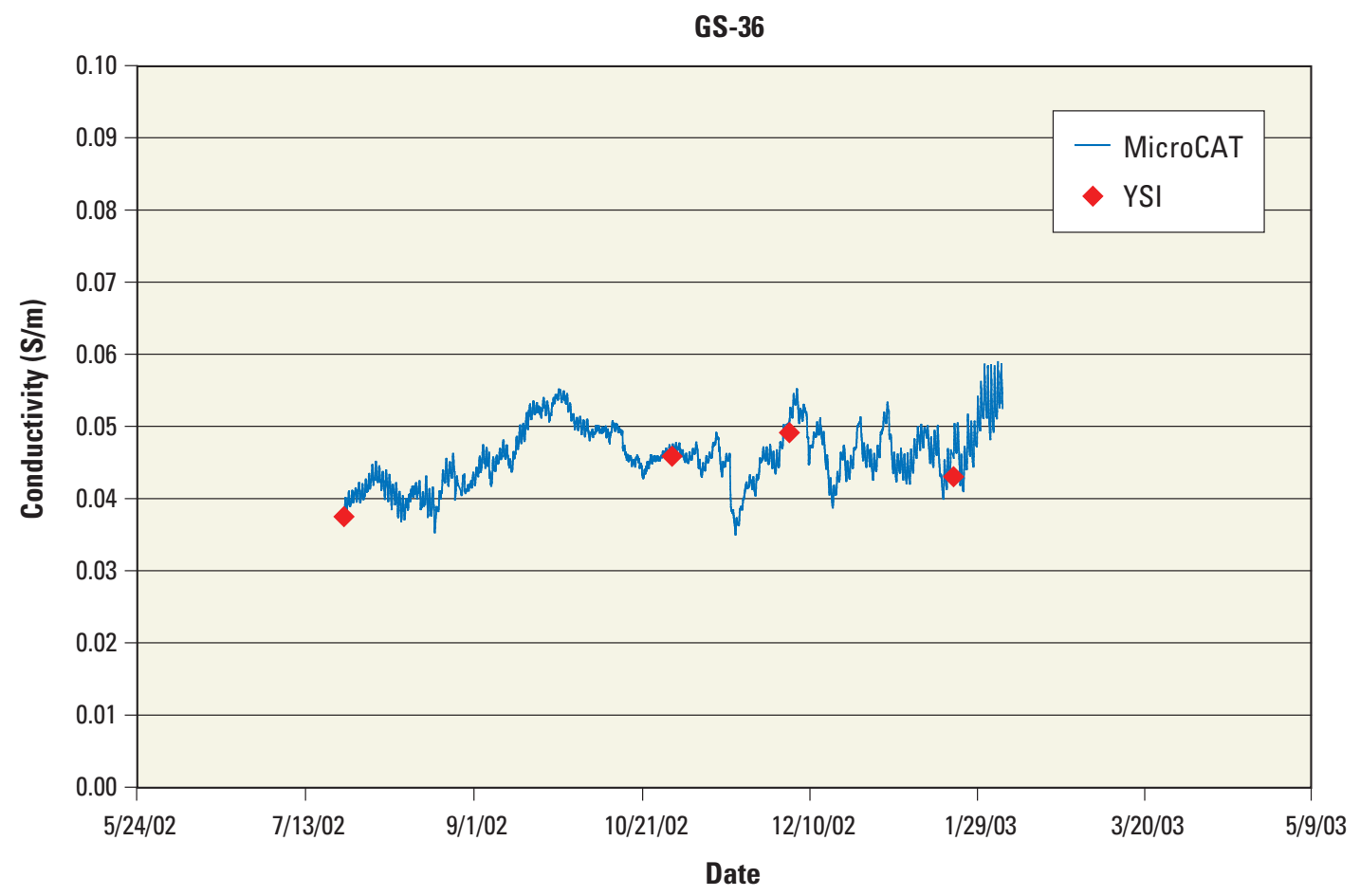

Figure 5. Conductivities measured continuously by MicroCAT probe and intermittently by hand-held YSI meter at GS-36 in Shark River Slough, Everglades National Park, during the 2002-2003 wet season. 


\section{Thermistor String Temperature Profile Data}

All temperature profile data from the thermistor strings were plotted and inspected for anomalies. Temperatures from the thermistor closest to the height of the MicroCAT probe above the litter layer also were compared to the MicroCAT recorded temperature. No suspect data were found in the visual inspection or in the MicroCAT comparisons.

\section{FLOW-VELOCITY, TEMPERATURE, AND CONDUCTIVITY DATA SUMMARY}

A summary of the data collected at all five monitoring sites SH1, GS-203, GS-33, GS-36, and NP202 during the 2002-2003 wet season is presented in the following report sections. Daily mean flow velocities, water temperatures, and specific conductances derived from measured conductivities are reported in Appendixes A, B, C, and D.

\section{Flow-Velocity Data}

Valid flow-velocity data were obtained from all deployments at all four ADV monitoring sites during the 2002-2003 wet season. Vectors showing burst-averaged velocity magnitudes and flow directions in the horizontal plane, relative to magnetic north, measured at sites SH1, GS-203, GS-33, and GS-36 are illustrated in figures $6,7,8$, and 9 , respectively. Horizontal velocity magnitudes for all deployments generally ranged from 0.11 to $1.99 \mathrm{~cm} / \mathrm{s}$ at SH1 (fig. 6), from 0.13 to $1.43 \mathrm{~cm} / \mathrm{s}$ at GS-203 (fig. 7), from 0.06 to $1.46 \mathrm{~cm} / \mathrm{s}$ at GS-33 (fig. 8), and from 0.01 to $2.56 \mathrm{~cm} / \mathrm{s}$ at GS-36 (fig. 9). Horizontal flow directions at all locations generally ranged from 180 to 275 degrees, clockwise with respect to magnetic north $(\mathrm{MN})$. (Declination corrections to Geodetic North are less than the plus or minus 2 degree accuracy of the ADV compass and, therefore, are not applied to the recorded velocity data.) Horizontal flow directions for all deployments averaged approximately 236 degrees at SH1, 240 degrees at GS203, 203 degrees at GS-33, and 229 degrees at GS-36. Corresponding daily mean horizontal-flow velocities are reported in tabular form for the SH1, GS-203, GS-33, and GS-36 sites in Appendixes A, B, C, and D, respectively.

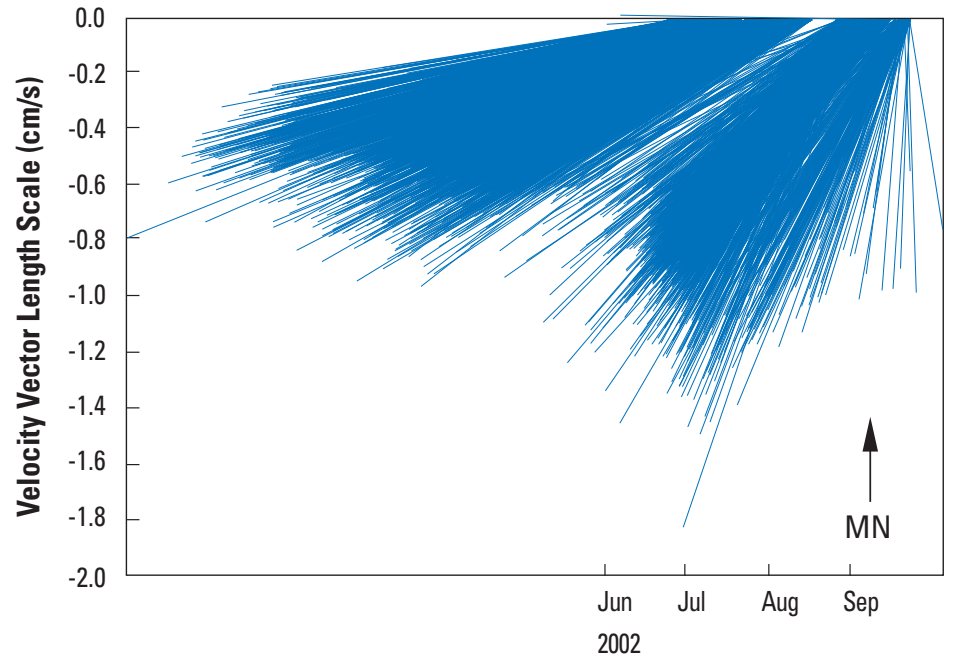

Figure 6. Burst-averaged flow velocities, shown as vectors relative to magnetic north, at $\mathrm{SH} 1$ in Shark River Sough, Everglades National Park, during the 2002-2003 wet season.

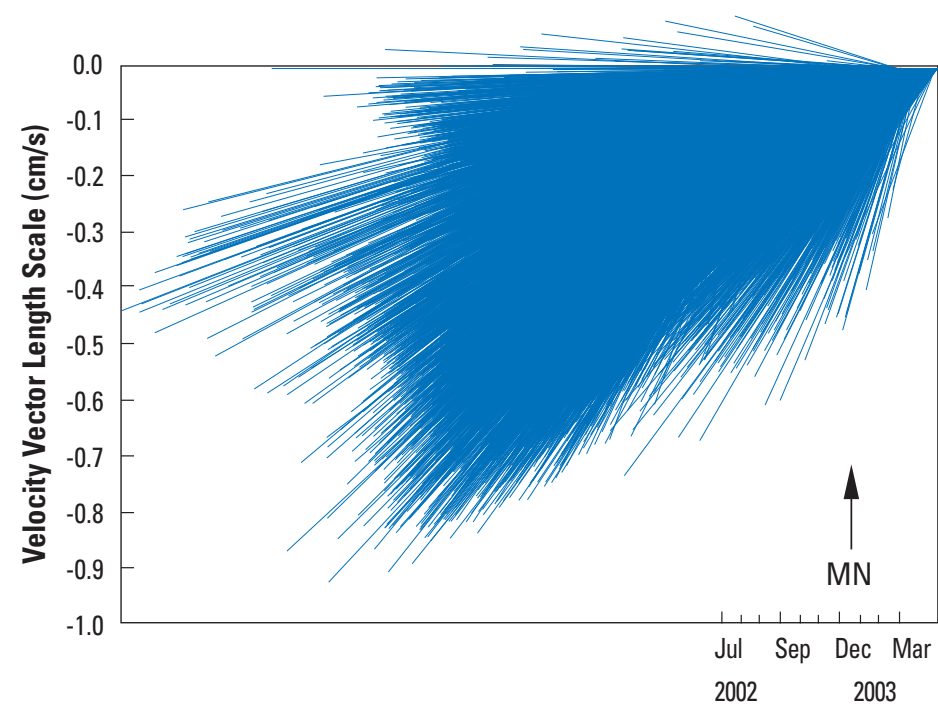

Figure 7. Burst-averaged flow velocities, shown as vectors relative to magnetic north, at GS-203 in Shark River Slough, Everglades National Park, during the 2002-2003 wet season. 


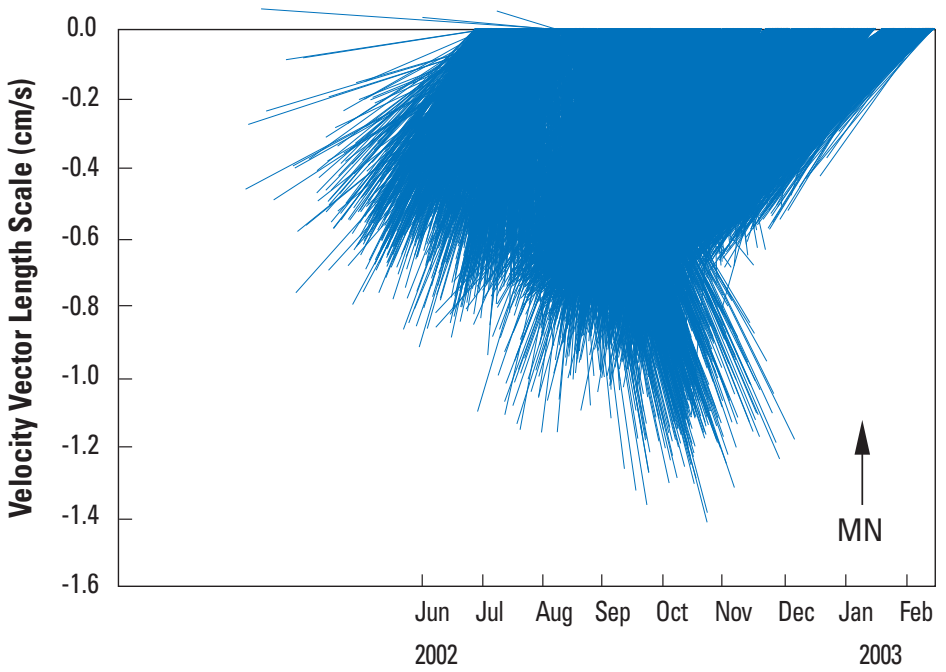

Figure 8. Burst-averaged flow velocities, shown as vectors relative to magnetic north, at GS-33 in Shark River Slough, Everglades National Park, during the 2002-2003 wet season.

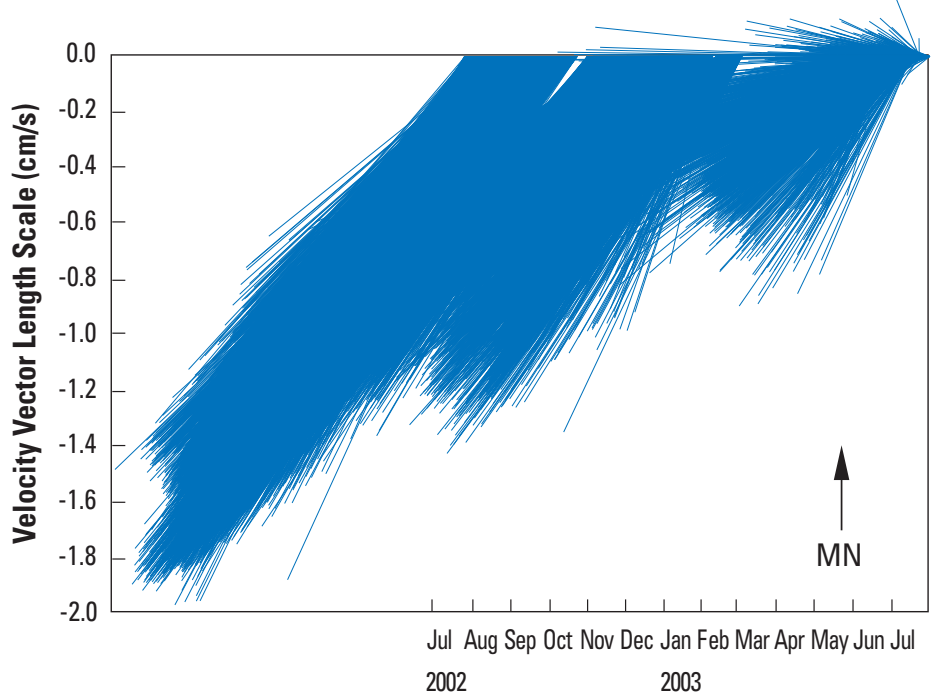

Figure 9. Burst-averaged flow velocities, shown as vectors relative to magnetic north, at GS-36 in Shark River Slough, Everglades National Park, during the 2002-2003 wet season.

\section{Temperature and Conductivity Data}

Water temperatures recorded during all deployments by the MicroCAT meter near the top of the litter layer ranged from approximately 10 to $36{ }^{\circ} \mathrm{C}$ at GS-203, 9 to $35^{\circ} \mathrm{C}$ at GS-33, and 10 to $39^{\circ} \mathrm{C}$ at GS-36. During all deployments, temperatures varied several degrees in a daily cyclical pattern. Specific conductance values, calculated from measured conductivities, for all deployments ranged from approximately 263 to $637 \mu \mathrm{S} / \mathrm{cm}$ at GS-203, 257 to $662 \mu \mathrm{S} / \mathrm{cm}$ at GS-33, and 316 to $624 \mu \mathrm{S} / \mathrm{cm}$ at GS-36. Daily mean water temperatures and specific conductances are reported in tabular form for GS203, GS-33, and GS-36 in Appendixes B, C, and D, respectively.

\section{Temperature Profile Data}

Water-column temperatures measured by the thermistor strings for all deployments at all sites ranged from approximately 9 to $38{ }^{\circ} \mathrm{C}$ in the 2002 2003 wet season. Daily vertical temperature gradients often approached 3 to $4{ }^{\circ} \mathrm{C}$. A typical temperature profile pattern, recorded at SH1, is illustrated and described in Riscassi and Schaffranek (2002).

\section{DATA AVAILABILITY}

Quality-checked and edited flow-velocity, water-temperature, and specific-conductance data, collected during the 2002-2003 wet season and summarized in this report, are available on the Data Exchange page of the USGS SOFIA website http:// sofia.usgs.gov. Three-dimensional velocity component data (including associated statistical correlation and SNR values), water temperatures, specific conductances, and water- and air-temperature profile data are available for downloading.

\section{SUMMARY}

The data-collection effort described in this report is in support of the U. S. Geological Survey (USGS) Priority Ecosystems Science project investigating "Forcing Effects on Flow Structure in Vegetated Wetlands of the Everglades." The acquisition, 
processing, and evaluation of flow-velocity, water-temperature, and conductivity data collected at five locations (sites SH1, GS-203, GS-33, GS-36, and NP202) in Shark River Slough, Everglades National Park, Florida, during the 2002-2003 wet season are documented. Temperatures were monitored at 15 -minute intervals throughout the water column at all five sites, 3-D flowvelocity components were monitored bi-hourly at a fixed point in the water column at SH1, GS-203, GS-33, and GS-36, and conductivities and temperatures were monitored bi-hourly near the top of the plant-litter layer at GS-203, GS-33, and GS-36. Velocity vectors defining horizontal flow speeds and directions measured at sites SH1, GS-203, GS-33, and GS-36 are illustrated in the report. Daily-mean horizontal flow velocities, water temperatures, and specific conductances are listed in tabular form in the report appendixes. The qualitychecked and edited data have been compiled and stored on the USGS SOFIA website http://sofia.usgs.gov.

\section{REFERENCES CITED}

Ball, M.H., and Schaffranek, R.W., 2000, Flow-velocity data collected in the wetlands adjacent to canal C-111 in south Florida during 1997 and 1999: U.S. Geological Survey Open- File Report 00-56, 56 p.

Riscassi, A.L. and Schaffranek, R.W., 2002, Flow velocity, water temperature, and conductivity in Shark River Slough, Everglades National Park, Florida: July 1999 - August 2001: U.S. Geological Survey Open-File Report 02-159, 32 p.

Riscassi, A.L. and Schaffranek, R.W., 2003, Flow velocity, water temperature, and conductivity in Shark River Slough, Everglades National Park, Florida: August 2001 - June 2002: U.S. Geological Survey Open-File Report 03-348, 37 p.

Sea-Bird Electronics, Inc., 1999, SBE 37-SI MicroCAT conductivity and temperature recorder with RS-232 Interface: User's manual version \# 010, 12/1/99, Bellevue, Wash., 41 p.

SonTek, 2001, SonTek ADV acoustic Doppler velocimeter technical documentation: San Diego, CA, 202 p.

Yellow Springs Instruments, 1998, YSI precision thermistors and probes: Yellow Springs, Ohio, 86 p. 
Appendix A. Daily mean flow velocities and water depths at station SH1, Shark River Slough, Everglades National Park, Florida during the 2002-2003 wet season. 
Table A-1. Daily mean flow velocities and water depths at station SH1 during deployment period 06/26/02 1500-08/27/02 1300 .

[cm/s, centimeters per second; ${ }^{\circ} \mathrm{CW}$ from $\mathrm{MN}$, degrees clockwise from magnetic north; $\mathrm{cm}$, centimeters; *, all bursts filtered out; \%, percent]

\begin{tabular}{|c|c|c|c|}
\hline Date & $\begin{array}{l}\text { Flow velocity }{ }^{1} \\
\qquad(\mathrm{~cm} / \mathrm{s})\end{array}$ & $\begin{array}{l}\text { Flow direction }{ }^{1} \\
\text { ( }^{\circ} \mathrm{CW} \text { from MN) }\end{array}$ & $\begin{array}{l}\text { Water depth }{ }^{2} \\
\qquad(\mathrm{~cm})\end{array}$ \\
\hline $06 / 27 / 02$ & 1.34 & 250 & 65 \\
\hline 06/28/02 & 1.55 & 253 & 65 \\
\hline 06/29/02 & 1.37 & 253 & 64 \\
\hline 06/30/02 & 1.34 & 255 & 63 \\
\hline 07/01/02 & 1.35 & 253 & 63 \\
\hline $07 / 02 / 02$ & 1.32 & 250 & 63 \\
\hline 07/03/02 & 0.93 & 252 & 62 \\
\hline 07/04/02 & 0.64 & 247 & 61 \\
\hline 07/05/02 & 0.62 & 241 & 60 \\
\hline 07/06/02 & 0.77 & 238 & 61 \\
\hline 07/07/02 & 0.75 & 243 & 60 \\
\hline 07/08/02 & 0.94 & 242 & 60 \\
\hline 07/09/02 & 0.96 & 243 & 61 \\
\hline 07/10/02 & 0.89 & 245 & 61 \\
\hline 07/11/02 & 0.89 & 245 & 62 \\
\hline 07/12/02 & 0.89 & 242 & 62 \\
\hline 07/13/02 & 0.98 & 242 & 61 \\
\hline 07/14/02 & 1.05 & 242 & 60 \\
\hline 07/15/02 & 1.12 & 243 & 58 \\
\hline 07/16/02 & 1.22 & 245 & 57 \\
\hline 07/17/02 & 1.36 & 249 & 56 \\
\hline 07/18/02 & 1.19 & 253 & 56 \\
\hline 07/19/02 & 1.36 & 250 & 55 \\
\hline 07/20/02 & 1.28 & 246 & 54 \\
\hline 07/21/02 & 1.37 & 248 & 53 \\
\hline $07 / 22 / 02$ & 1.29 & 249 & 54 \\
\hline 07/23/02 & 1.28 & 249 & 53 \\
\hline 07/24/02 & 1.19 & 247 & 51 \\
\hline $07 / 25 / 02$ & 1.55 & 241 & 51 \\
\hline 07/26/02 & 1.22 & 244 & 50 \\
\hline 07/27/02 & 1.14 & 247 & 49 \\
\hline 07/28/02 & 1.08 & 248 & 48 \\
\hline 07/29/02 & 1.10 & 247 & 46 \\
\hline
\end{tabular}


Table A-1. Daily mean flow velocities and water depths at station SH1 during deployment period 06/26/02 1500-08/27/02 1300-Continued

\begin{tabular}{|c|c|c|c|}
\hline Date & $\begin{array}{l}\text { Flow velocity }{ }^{1} \\
\quad(\mathrm{~cm} / \mathrm{s})\end{array}$ & $\begin{array}{l}\text { Flow direction }{ }^{1} \\
\left({ }^{\circ} \mathrm{CW} \text { from } \mathrm{MN}\right)\end{array}$ & $\begin{array}{l}\text { Water depth } \\
\quad \text { (cm) }\end{array}$ \\
\hline 07/30/02 & 1.04 & 248 & 46 \\
\hline 07/31/02 & 1.16 & 242 & 45 \\
\hline 08/01/02 & 1.06 & 240 & 45 \\
\hline 08/02/02 & 0.97 & 244 & 44 \\
\hline 08/03/02 & 1.08 & 242 & 43 \\
\hline 08/04/02 & 1.01 & 242 & 43 \\
\hline 08/05/02 & 1.02 & 241 & 43 \\
\hline 08/06/02 & 1.14 & 242 & 43 \\
\hline 08/07/02 & 1.21 & 244 & 43 \\
\hline 08/08/02 & 1.24 & 244 & 43 \\
\hline 08/09/02 & 1.23 & 246 & 43 \\
\hline 08/10/02 & 1.25 & 244 & 43 \\
\hline 08/11/02 & 1.32 & 246 & 43 \\
\hline 08/12/02 & 1.26 & 245 & 43 \\
\hline 08/13/02 & 1.25 & 241 & 44 \\
\hline 08/14/02 & 1.15 & 243 & 44 \\
\hline 08/15/02 & 1.02 & 242 & 45 \\
\hline 08/16/02 & 1.07 & 242 & 45 \\
\hline 08/17/02 & 1.02 & 241 & 45 \\
\hline 08/18/02 & 1.29 & 241 & 45 \\
\hline 08/19/02 & $*$ & $*$ & 47 \\
\hline 08/20/02 & * & $*$ & 47 \\
\hline 08/21/02 & * & $*$ & 48 \\
\hline 08/22/02 & * & * & 48 \\
\hline 08/23/02 & * & $*$ & 49 \\
\hline 08/24/02 & * & * & 48 \\
\hline 08/25/02 & $*$ & $*$ & 48 \\
\hline 08/26/02 & $*$ & $*$ & 48 \\
\hline MINIMUM & 0.62 & 238 & 43 \\
\hline MAXIMUM & 1.55 & 255 & 65 \\
\hline AVERAGE & 1.13 & 245 & 52 \\
\hline $\begin{array}{l}\text { BURSTS } \\
\text { FILTERED } \\
\text { OUT }(\%)\end{array}$ & 18 & & \\
\hline
\end{tabular}

${ }^{1}$ Flow sample volume located $34 \mathrm{~cm}$ above top of litter.

${ }^{2}$ Depth variation determined from stage recorded at SH1 gage. 
Table A-2. Daily mean flow velocities and water depths at station SH1 during deployment period 08/28/02 1029-09/25/02 0859.

$\left[\mathrm{cm} / \mathrm{s}\right.$, centimeters per second; ${ }^{\circ} \mathrm{CW}$ from $\mathrm{MN}$, degrees clockwise from magnetic north; cm, centimeters; *, all bursts filtered out; $\%$, percent]

\begin{tabular}{|c|c|c|c|}
\hline Date & $\begin{array}{c}\text { Flow velocity }{ }^{1} \\
(\mathrm{~cm} / \mathrm{s})\end{array}$ & $\begin{array}{l}\text { Flow direction }{ }^{1} \\
\left(^{\circ} \mathrm{CW} \text { from } \mathrm{MN} \text { ) }\right.\end{array}$ & $\begin{array}{l}\text { Water depth } \\
\text { (cm) }\end{array}$ \\
\hline 08/29/02 & 0.95 & 219 & 51 \\
\hline 08/30/02 & 0.94 & 222 & 51 \\
\hline 08/31/02 & 1.06 & 212 & 52 \\
\hline 09/01/02 & 1.09 & 210 & 53 \\
\hline $09 / 02 / 02$ & 1.06 & 212 & 53 \\
\hline 09/03/02 & 1.13 & 208 & 53 \\
\hline 09/04/02 & 1.16 & 210 & 53 \\
\hline 09/05/02 & 0.99 & 220 & 54 \\
\hline 09/06/02 & 1.00 & 221 & 55 \\
\hline 09/07/02 & 1.11 & 217 & 55 \\
\hline 09/08/02 & 1.05 & 221 & 56 \\
\hline 09/09/02 & 1.06 & 221 & 56 \\
\hline 09/10/02 & 1.06 & 223 & 56 \\
\hline 09/11/02 & 1.15 & 219 & 56 \\
\hline 09/12/02 & 1.14 & 220 & 57 \\
\hline 09/13/02 & 1.07 & 224 & 57 \\
\hline 09/14/02 & 1.06 & 225 & 56 \\
\hline 09/15/02 & 1.06 & 224 & 56 \\
\hline 09/16/02 & 1.11 & 224 & 55 \\
\hline 09/17/02 & 1.10 & 219 & 54 \\
\hline 09/18/02 & $*$ & $*$ & 53 \\
\hline 09/19/02 & 1.00 & 212 & 53 \\
\hline 09/20/02 & 0.91 & 211 & 52 \\
\hline $09 / 21 / 02$ & 0.86 & 213 & 52 \\
\hline $09 / 22 / 02$ & 0.78 & 210 & 51 \\
\hline 09/23/02 & 1.07 & 209 & 52 \\
\hline $09 / 24 / 02$ & 0.97 & 208 & 52 \\
\hline MINIMUM & 0.78 & 208 & 51 \\
\hline MAXIMUM & 1.16 & 225 & 57 \\
\hline AVERAGE & 1.04 & 217 & 54 \\
\hline $\begin{array}{l}\text { BURSTS } \\
\text { FILTERED } \\
\text { OUT }(\%)\end{array}$ & 8 & & \\
\hline
\end{tabular}

${ }^{1}$ Flow sample volume located $34 \mathrm{~cm}$ above top of litter.

${ }^{2}$ Depth variation determined from stage recorded at SH1 gage. 
Appendix B. Daily mean flow velocities, water temperatures, specific conductances, and water depths at station GS-203, Shark River Slough, Everglades National Park, Florida during the 2002-2003 wet season. 
Table B - 1. Daily mean flow velocities, MicroCAT water temperatures and specific conductances, and water depths at station GS-203 during deployment period 06/27/02 1200-08/27/02 1500.

$\left[\mathrm{cm} / \mathrm{s}\right.$, centimeters per second; ${ }^{\circ} \mathrm{CW}$ from MN, degrees clockwise from magnetic north; ${ }^{\circ} \mathrm{C}$, degrees Celsius; $\mu \mathrm{S} / \mathrm{cm}$ microsiemens per centimeter at 25 degrees Celsius; cm, centimeters; *, all bursts filtered out; --, no data; \%, percent]

\begin{tabular}{|c|c|c|c|c|c|}
\hline Date & $\begin{array}{l}\text { Flow velocity }{ }^{1} \\
\qquad(\mathrm{~cm} / \mathrm{s})\end{array}$ & $\begin{array}{l}\text { Flow direction }{ }^{1} \\
\text { ( }{ }^{\circ} \mathrm{CW} \text { from MN) }\end{array}$ & $\begin{array}{c}\text { Temperature }^{2} \\
\left({ }^{\circ} \mathrm{C}\right)\end{array}$ & $\begin{array}{c}\text { Specific } \\
\text { conductance }^{2} \\
\text { ( } \mathrm{SS} / \mathrm{cm})\end{array}$ & $\begin{array}{l}\text { Water depth } \\
\text { (cm) }\end{array}$ \\
\hline $06 / 28 / 02$ & 1.14 & 252 & 28.44 & 295 & 40 \\
\hline 06/29/02 & 0.86 & 252 & 29.20 & 293 & 40 \\
\hline 06/30/02 & 0.64 & 248 & 29.59 & 286 & 38 \\
\hline 07/01/02 & 0.65 & 243 & 29.17 & 294 & 38 \\
\hline 07/02/02 & 0.53 & 240 & 29.27 & 292 & 37 \\
\hline 07/03/02 & 0.61 & 259 & 30.70 & 291 & 37 \\
\hline 07/04/02 & $*$ & $*$ & 31.59 & 290 & 37 \\
\hline 07/05/02 & * & $*$ & 31.77 & 295 & 36 \\
\hline 07/06/02 & $*$ & $*$ & 29.96 & 294 & 37 \\
\hline 07/07/02 & $*$ & $*$ & 29.94 & 292 & 38 \\
\hline 07/08/02 & $*$ & $*$ & 28.66 & 291 & 39 \\
\hline 07/09/02 & $*$ & $*$ & 27.46 & 284 & 41 \\
\hline 07/10/02 & $*$ & $*$ & 27.25 & 279 & 42 \\
\hline 07/11/02 & * & $*$ & 27.31 & 274 & 43 \\
\hline 07/12/02 & $*$ & $*$ & 29.39 & 276 & 44 \\
\hline 07/13/02 & $*$ & $*$ & 31.15 & 274 & 45 \\
\hline 07/14/02 & $*$ & $*$ & 32.50 & 277 & 45 \\
\hline 07/15/02 & $*$ & $*$ & 33.16 & 278 & 45 \\
\hline 07/16/02 & $*$ & $*$ & 32.47 & 282 & 45 \\
\hline 07/17/02 & $*$ & $*$ & 32.43 & 281 & 46 \\
\hline 07/18/02 & $*$ & $*$ & 31.78 & 283 & 46 \\
\hline 07/19/02 & $*$ & $*$ & 31.50 & 293 & 46 \\
\hline 07/20/02 & $*$ & $*$ & 32.30 & 298 & 46 \\
\hline 07/21/02 & $*$ & $*$ & 32.45 & 305 & 45 \\
\hline 07/22/02 & $*$ & $*$ & 31.43 & 310 & 45 \\
\hline 07/23/02 & 0.73 & 245 & 30.96 & 309 & 45 \\
\hline 07/24/02 & 0.68 & 236 & 30.72 & 314 & 45 \\
\hline 07/25/02 & 0.75 & 235 & 31.20 & 317 & 45 \\
\hline $07 / 26 / 02$ & 0.82 & 231 & 31.64 & 324 & 44 \\
\hline 07/27/02 & 0.74 & 232 & 31.95 & 333 & 44 \\
\hline 07/28/02 & 0.77 & 232 & 32.00 & 342 & 44 \\
\hline 07/29/02 & 0.71 & 231 & 31.67 & 350 & 44 \\
\hline 07/30/02 & 0.70 & 232 & 31.65 & 358 & 44 \\
\hline 07/31/02 & 0.72 & 233 & 31.98 & 367 & 44 \\
\hline
\end{tabular}


Table B - 1. Daily mean flow velocities, MicroCAT water temperatures and specific conductances, and water depths at station GS-203 during deployment period 06/27/02 1200-08/27/02 1500-Continued

\begin{tabular}{|c|c|c|c|c|c|}
\hline Date & $\begin{array}{l}\text { Flow velocity }{ }^{1} \\
\text { (cm/s) }\end{array}$ & $\begin{array}{l}\text { Flow direction }{ }^{1} \\
\left({ }^{\circ} \mathrm{CW} \text { from MN) }\right.\end{array}$ & $\begin{array}{c}\text { Temperature }{ }^{2} \\
\left({ }^{\circ} \mathrm{C}\right)\end{array}$ & $\begin{array}{c}\text { Specific } \\
\text { conductance }^{2} \\
(\mu \mathrm{S} / \mathrm{cm})\end{array}$ & $\begin{array}{l}\text { Water depth }{ }^{3} \\
\text { (cm) }\end{array}$ \\
\hline 08/01/02 & 0.70 & 229 & 32.16 & 375 & 44 \\
\hline 08/02/02 & 0.78 & 228 & 32.59 & 383 & 44 \\
\hline 08/03/02 & 0.75 & 226 & 32.71 & 394 & 44 \\
\hline 08/04/02 & 0.66 & 226 & 32.04 & 401 & 45 \\
\hline 08/05/02 & 0.66 & 226 & 31.38 & 408 & 45 \\
\hline 08/06/02 & 0.80 & 222 & 31.89 & 426 & 46 \\
\hline 08/07/02 & 0.95 & 226 & 31.28 & 442 & 46 \\
\hline 08/08/02 & 0.94 & 222 & 30.48 & 454 & 47 \\
\hline 08/09/02 & 0.90 & 225 & 31.15 & 458 & 47 \\
\hline 08/10/02 & 0.55 & 220 & 30.05 & 464 & 47 \\
\hline 08/11/02 & $*$ & $*$ & 28.75 & 458 & 47 \\
\hline 08/12/02 & $*$ & $*$ & 28.49 & 442 & 50 \\
\hline 08/13/02 & $*$ & $*$ & 29.72 & 437 & 50 \\
\hline 08/14/02 & $*$ & $*$ & 29.93 & 441 & 50 \\
\hline 08/15/02 & $*$ & $*$ & 30.48 & 447 & 50 \\
\hline 08/16/02 & $*$ & $*$ & 30.46 & 457 & 50 \\
\hline 08/17/02 & $*$ & $*$ & 30.53 & 472 & 50 \\
\hline 08/18/02 & $*$ & $*$ & 31.10 & 486 & 50 \\
\hline 08/19/02 & $*$ & * & 30.96 & 496 & 50 \\
\hline 08/20/02 & $*$ & $*$ & 30.39 & 499 & 50 \\
\hline 08/21/02 & $*$ & $*$ & 29.43 & 505 & 50 \\
\hline 08/22/02 & $*$ & $*$ & 30.18 & 511 & 51 \\
\hline 08/23/02 & $*$ & $*$ & 31.07 & 515 & -- \\
\hline 08/24/02 & $*$ & $*$ & 30.97 & 518 & -- \\
\hline $08 / 25 / 02$ & 0.65 & 246 & 31.05 & 518 & 50 \\
\hline 08/26/02 & 0.79 & 252 & 31.60 & 521 & 50 \\
\hline MINIMUM & 0.53 & 220 & 27.25 & 274 & 36 \\
\hline MAXIMUM & 0.95 & 259 & 33.16 & 521 & 51 \\
\hline AVERAGE & 0.75 & 235 & 30.76 & 369 & 45 \\
\hline $\begin{array}{l}\text { BURSTS } \\
\text { FILTERED } \\
\text { OUT }(\%)\end{array}$ & 59 & & & & \\
\hline
\end{tabular}

${ }^{1}$ Flow sample volume located $19 \mathrm{~cm}$ above top of litter.

${ }^{2}$ MicroCAT temperature and conductance measured $11 \mathrm{~cm}$ above top of litter.

${ }^{3}$ Depth variation determined from stage recorded at NP203 gage. 
Table B - 2. Daily mean flow velocities, MicroCAT water temperatures and specific conductances, and water depths at station GS-203 during deployment period 08/28/02 1300-10/29/02 1600.

$\left[\mathrm{cm} / \mathrm{s}\right.$, centimeters per second; ${ }^{\circ} \mathrm{CW}$ from $\mathrm{MN}$, degrees clockwise from magnetic north; ${ }^{\circ} \mathrm{C}$, degrees Celsius; $\mu \mathrm{S} / \mathrm{cm}$ microsiemens per centimeter at 25 degrees Celsius; cm, centimeters; --, no data; \%, percent]

\begin{tabular}{|c|c|c|c|c|c|}
\hline Date & $\begin{array}{l}\text { Flow velocity }{ }^{1} \\
\text { (cm/s) }\end{array}$ & $\begin{array}{l}\text { Flow direction }{ }^{1} \\
\left({ }^{\circ} \mathrm{CW} \text { from } \mathrm{MN}\right)\end{array}$ & $\begin{array}{c}\text { Temperature }^{2} \\
\left({ }^{\circ} \mathrm{C}\right)\end{array}$ & $\begin{array}{c}\text { Specific } \\
\text { conductance }^{2} \\
(\mu \mathrm{S} / \mathrm{cm})\end{array}$ & $\begin{array}{l}\text { Water depth } \\
\text { (cm) }\end{array}$ \\
\hline 08/29/02 & 0.87 & 230 & 29.30 & 489 & 53 \\
\hline 08/30/02 & 0.86 & 228 & 28.62 & 471 & -- \\
\hline 08/31/02 & 0.85 & 229 & 28.90 & 480 & -- \\
\hline 09/01/02 & 0.90 & 230 & 29.77 & 487 & -- \\
\hline 09/02/02 & 0.93 & 231 & 30.44 & 486 & 53 \\
\hline 09/03/02 & 0.99 & 239 & 30.36 & 471 & -- \\
\hline 09/04/02 & 0.95 & 235 & 30.36 & 446 & -- \\
\hline 09/05/02 & 0.96 & 234 & 30.37 & 427 & -- \\
\hline 09/06/02 & 0.96 & 237 & 29.68 & 408 & -- \\
\hline 09/07/02 & 0.95 & 235 & 29.78 & 392 & -- \\
\hline 09/08/02 & 0.88 & 235 & 29.71 & 387 & -- \\
\hline 09/09/02 & 0.89 & 235 & 30.18 & 395 & -- \\
\hline 09/10/02 & 0.78 & 232 & 30.25 & 398 & -- \\
\hline 09/11/02 & 0.73 & 229 & 28.96 & 395 & -- \\
\hline 09/12/02 & 0.66 & 224 & 27.29 & 381 & -- \\
\hline 09/13/02 & 0.67 & 225 & 27.84 & 390 & -- \\
\hline 09/14/02 & 0.69 & 224 & 28.96 & 392 & -- \\
\hline 09/15/02 & 0.75 & 224 & 29.83 & 396 & -- \\
\hline 09/16/02 & 0.79 & 225 & 30.00 & 392 & -- \\
\hline 09/17/02 & 0.77 & 224 & 30.55 & 387 & -- \\
\hline 09/18/02 & 0.72 & 227 & 30.84 & 384 & -- \\
\hline 09/19/02 & 0.65 & 226 & 30.71 & 383 & -- \\
\hline 09/20/02 & 0.72 & 229 & 30.36 & 381 & -- \\
\hline $09 / 21 / 02$ & 0.76 & 227 & 29.78 & 378 & -- \\
\hline 09/22/02 & 0.77 & 226 & 29.72 & 377 & -- \\
\hline 09/23/02 & 0.84 & 232 & 28.81 & 376 & -- \\
\hline $09 / 24 / 02$ & 0.88 & 229 & 28.44 & 376 & -- \\
\hline 09/25/02 & 0.85 & 229 & 29.18 & 376 & 55 \\
\hline 09/26/02 & 0.82 & 226 & 29.46 & 385 & 55 \\
\hline 09/27/02 & 0.79 & 228 & 30.11 & 384 & 56 \\
\hline 09/28/02 & 0.63 & 223 & 30.19 & 371 & 56 \\
\hline 09/29/02 & 0.43 & 232 & 30.17 & 362 & 56 \\
\hline 09/30/02 & 0.41 & 235 & 29.46 & 358 & 55 \\
\hline
\end{tabular}


Table B - 2. Daily mean flow velocities, MicroCAT water temperatures and specific conductances, and water depths at station GS-203 during deployment period 08/28/02 1300-10/29/02 1600—Continued

\begin{tabular}{|c|c|c|c|c|c|}
\hline Date & $\begin{array}{l}\text { Flow velocity }{ }^{1} \\
(\mathrm{~cm} / \mathrm{s})\end{array}$ & $\begin{array}{l}\text { Flow direction }{ }^{1} \\
\left({ }^{\circ} \mathrm{CW} \text { from } \mathrm{MN}\right)\end{array}$ & $\begin{array}{l}\text { Temperature }{ }^{2} \\
\left({ }^{\circ} \mathrm{C}\right)\end{array}$ & $\begin{array}{c}\text { Specific } \\
\text { conductance }{ }^{2} \\
(\mu \mathrm{S} / \mathrm{cm})\end{array}$ & $\begin{array}{l}\text { Water depth } \\
\quad \text { (cm) }\end{array}$ \\
\hline $10 / 01 / 02$ & 0.52 & 232 & 29.31 & 367 & 55 \\
\hline $10 / 02 / 02$ & 0.53 & 232 & 29.52 & 374 & 54 \\
\hline $10 / 03 / 02$ & 0.56 & 233 & 29.53 & 381 & 54 \\
\hline $10 / 04 / 02$ & 0.62 & 227 & 29.06 & 389 & 53 \\
\hline $10 / 05 / 02$ & 0.84 & 223 & 29.47 & 388 & 53 \\
\hline $10 / 06 / 02$ & 0.75 & 223 & 28.88 & 394 & 54 \\
\hline $10 / 07 / 02$ & 0.78 & 224 & 28.74 & 392 & 53 \\
\hline $10 / 08 / 02$ & 0.78 & 222 & 28.97 & 394 & 53 \\
\hline 10/09/02 & 0.76 & 223 & 28.58 & 400 & 53 \\
\hline $10 / 10 / 02$ & 0.96 & 226 & 28.92 & 403 & 52 \\
\hline $10 / 11 / 02$ & 1.05 & 226 & 29.31 & 394 & 53 \\
\hline $10 / 12 / 02$ & 0.95 & 223 & 29.32 & 406 & 54 \\
\hline $10 / 13 / 02$ & 0.97 & 226 & 29.41 & 408 & 53 \\
\hline $10 / 14 / 02$ & 0.92 & 225 & 29.12 & 413 & 53 \\
\hline $10 / 15 / 02$ & 0.93 & 223 & 28.88 & 420 & 52 \\
\hline $10 / 16 / 02$ & 0.91 & 226 & 28.30 & 407 & 54 \\
\hline 10/17/02 & 0.90 & 229 & 27.20 & 397 & 54 \\
\hline $10 / 18 / 02$ & 0.82 & 225 & 26.08 & 391 & 53 \\
\hline $10 / 19 / 02$ & 0.80 & 226 & 25.84 & 394 & 53 \\
\hline $10 / 20 / 02$ & 0.80 & 227 & 26.61 & 404 & 53 \\
\hline $10 / 21 / 02$ & 0.84 & 228 & 26.72 & 414 & 53 \\
\hline $10 / 22 / 02$ & 0.78 & 227 & 26.96 & 418 & 53 \\
\hline $10 / 23 / 02$ & 0.78 & 227 & 28.05 & 423 & 53 \\
\hline $10 / 24 / 02$ & 0.82 & 226 & 28.35 & 429 & 52 \\
\hline $10 / 25 / 02$ & 0.79 & 225 & 28.69 & 439 & 52 \\
\hline $10 / 26 / 02$ & 0.72 & 226 & 28.64 & 446 & 52 \\
\hline $10 / 27 / 02$ & 0.73 & 225 & 28.85 & 452 & 52 \\
\hline $10 / 28 / 02$ & 0.69 & 223 & 28.63 & 460 & 51 \\
\hline MINIMUM & 0.41 & 222 & 25.84 & 358 & 51 \\
\hline MAXIMUM & 1.05 & 239 & 30.84 & 489 & 56 \\
\hline AVERAGE & 0.79 & 228 & 29.09 & 406 & 53 \\
\hline $\begin{array}{l}\text { BURSTS } \\
\text { FILTERED } \\
\text { OUT }(\%)\end{array}$ & 0 & & & & \\
\hline
\end{tabular}

${ }^{1}$ Flow sample volume located $19 \mathrm{~cm}$ above top of litter.

${ }^{2}$ MicroCAT temperature and conductance measured $11 \mathrm{~cm}$ above top of litter.

${ }^{3}$ Depth variation determined from stage recorded at NP203 gage. 
Table B - 3. Daily mean flow velocities, MicroCAT water temperatures and specific conductances, and water depths at station GS-203 during deployment period 10/30/02 $1200-12 / 03 / 021330$.

$\left[\mathrm{cm} / \mathrm{s}\right.$, centimeters per second; ${ }^{\circ} \mathrm{CW}$ from $\mathrm{MN}$, degrees clockwise from magnetic north; ${ }^{\circ} \mathrm{C}$, degrees Celsius; $\mu \mathrm{S} / \mathrm{cm}$ microsiemens per centimeter at 25 degrees Celsius; cm, centimeters; \%, percent]

\begin{tabular}{|c|c|c|c|c|c|}
\hline Date & $\begin{array}{l}\text { Flow velocity }{ }^{1} \\
\qquad(\mathrm{~cm} / \mathrm{s})\end{array}$ & $\begin{array}{l}\text { Flow direction }{ }^{1} \\
\left({ }^{\circ} \mathrm{CW} \text { from MN) }\right.\end{array}$ & $\begin{array}{c}\text { Temperature }{ }^{2} \\
\left({ }^{\circ} \mathrm{C}\right)\end{array}$ & $\begin{array}{c}\text { Specific } \\
\text { conductance }^{2} \\
(\mu \mathrm{S} / \mathrm{cm})\end{array}$ & $\begin{array}{l}\text { Water depth } \\
\text { (cm) }\end{array}$ \\
\hline $10 / 31 / 02$ & 0.82 & 235 & 28.59 & 472 & 50 \\
\hline $11 / 01 / 02$ & 0.85 & 235 & 28.43 & 474 & 50 \\
\hline $11 / 02 / 02$ & 0.80 & 235 & 27.44 & 479 & 49 \\
\hline $11 / 03 / 02$ & 0.81 & 236 & 26.50 & 482 & 49 \\
\hline $11 / 04 / 02$ & 0.81 & 237 & 26.24 & 483 & 48 \\
\hline $11 / 05 / 02$ & 0.80 & 238 & 26.36 & 484 & 48 \\
\hline $11 / 06 / 02$ & 0.80 & 237 & 26.69 & 484 & 48 \\
\hline $11 / 07 / 02$ & 0.76 & 234 & 24.42 & 484 & 48 \\
\hline $11 / 08 / 02$ & 0.78 & 235 & 22.82 & 484 & 47 \\
\hline $11 / 09 / 02$ & 0.81 & 236 & 23.33 & 483 & 47 \\
\hline $11 / 10 / 02$ & 0.94 & 235 & 23.94 & 483 & 47 \\
\hline $11 / 11 / 02$ & 1.01 & 234 & 24.63 & 484 & 47 \\
\hline $11 / 12 / 02$ & 1.02 & 234 & 25.87 & 485 & 47 \\
\hline $11 / 13 / 02$ & 0.85 & 237 & 25.05 & 484 & 47 \\
\hline $11 / 14 / 02$ & 0.76 & 245 & 21.82 & 487 & 46 \\
\hline $11 / 15 / 02$ & 0.76 & 247 & 22.29 & 490 & 45 \\
\hline $11 / 16 / 02$ & 0.79 & 246 & 22.90 & 478 & 46 \\
\hline $11 / 17 / 02$ & 0.88 & 250 & 22.25 & 428 & 52 \\
\hline $11 / 18 / 02$ & 0.74 & 248 & 18.92 & 423 & 51 \\
\hline
\end{tabular}


Table B - 3. Daily mean flow velocities, MicroCAT water temperatures and specific conductances, and water depths at station GS-203 during deployment period 10/30/02 1200-12/03/02 1330-Continued

\begin{tabular}{|c|c|c|c|c|c|}
\hline Date & $\begin{array}{l}\text { Flow velocity' } \\
\quad(\mathrm{cm} / \mathrm{s})\end{array}$ & $\begin{array}{l}\text { Flow direction }{ }^{1} \\
\left({ }^{\circ} \mathrm{CW} \text { from } \mathrm{MN}\right)\end{array}$ & $\begin{array}{l}\text { Temperature }^{2} \\
\left({ }^{\circ} \mathrm{C}\right)\end{array}$ & $\begin{array}{c}\text { Specific } \\
\text { conductance }{ }^{2} \\
(\mu \mathrm{S} / \mathrm{cm})\end{array}$ & $\begin{array}{l}\text { Water depth } \\
\quad \text { (cm) }\end{array}$ \\
\hline $11 / 19 / 02$ & 0.79 & 249 & 18.72 & 422 & 50 \\
\hline $11 / 20 / 02$ & 0.71 & 249 & 20.04 & 414 & 49 \\
\hline $11 / 21 / 02$ & 0.62 & 251 & 21.83 & 437 & 48 \\
\hline $11 / 22 / 02$ & 0.75 & 256 & 22.68 & 441 & 48 \\
\hline $11 / 23 / 02$ & 0.74 & 253 & 20.98 & 439 & 47 \\
\hline $11 / 24 / 02$ & 0.65 & 252 & 19.60 & 444 & 46 \\
\hline $11 / 25 / 02$ & 0.58 & 256 & 20.49 & 444 & 45 \\
\hline $11 / 26 / 02$ & 0.62 & 254 & 21.59 & 450 & 44 \\
\hline $11 / 27 / 02$ & 0.75 & 255 & 21.36 & 453 & 44 \\
\hline $11 / 28 / 02$ & 0.75 & 252 & 20.82 & 452 & 43 \\
\hline $11 / 29 / 02$ & 0.81 & 255 & 19.40 & 452 & 42 \\
\hline $11 / 30 / 02$ & 0.80 & 254 & 18.31 & 454 & 41 \\
\hline $12 / 01 / 02$ & 0.80 & 254 & 18.62 & 460 & 41 \\
\hline $12 / 02 / 02$ & 0.90 & 250 & 19.62 & 466 & 45 \\
\hline MINIMUM & 0.58 & 234 & 18.31 & 414 & 41 \\
\hline MAXIMUM & 1.02 & 256 & 28.59 & 490 & 52 \\
\hline AVERAGE & 0.79 & 245 & 22.80 & 463 & 47 \\
\hline $\begin{array}{l}\text { BURSTS } \\
\text { FILTERED } \\
\text { OUT }(\%)\end{array}$ & 1 & & & & \\
\hline
\end{tabular}

${ }^{1}$ Flow sample volume located $19 \mathrm{~cm}$ above top of litter.

${ }^{2}$ MicroCAT temperature and conductance measured $11 \mathrm{~cm}$ above top of litter.

${ }^{3}$ Depth variation determined from stage recorded at NP203 gage. 
Table B - 4. Daily mean flow velocities, MicroCAT water temperatures and specific conductances, and water depths at station GS-203 during deployment period 12/04/02 1200-01/21/03 1330.

$\left[\mathrm{cm} / \mathrm{s}\right.$, centimeters per second; ${ }^{\circ} \mathrm{CW}$ from $\mathrm{MN}$, degrees clockwise from magnetic north; ${ }^{\circ} \mathrm{C}$, degrees Celsius; $\mu \mathrm{S} / \mathrm{cm}$ microsiemens per centimeter at 25 degrees Celsius; cm, centimeters; \%, percent]

\begin{tabular}{|c|c|c|c|c|c|}
\hline Date & $\begin{array}{l}\text { Flow velocity }{ }^{1} \\
\text { (cm/s) }\end{array}$ & $\begin{array}{l}\text { Flow direction }{ }^{1} \\
\text { ( }{ }^{\circ} \mathrm{CW} \text { from MN) }\end{array}$ & $\begin{array}{c}\text { Temperature }{ }^{2} \\
\left({ }^{\circ} \mathrm{C}\right)\end{array}$ & $\begin{array}{c}\text { Specific } \\
\text { conductance }^{2} \\
(\mu \mathrm{S} / \mathrm{cm})\end{array}$ & $\begin{array}{l}\text { Water depth } \\
\text { (cm) }\end{array}$ \\
\hline $12 / 05 / 02$ & 0.90 & 259 & 22.08 & 474 & 40 \\
\hline $12 / 06 / 02$ & 0.89 & 260 & 23.03 & 479 & 40 \\
\hline $12 / 07 / 02$ & 0.92 & 262 & 21.34 & 487 & 39 \\
\hline $12 / 08 / 02$ & 0.94 & 263 & 21.39 & 494 & 39 \\
\hline $12 / 09 / 02$ & 0.85 & 262 & 21.68 & 490 & 39 \\
\hline $12 / 10 / 02$ & 0.88 & 264 & 22.09 & 457 & 39 \\
\hline $12 / 11 / 02$ & 0.84 & 262 & 22.66 & 448 & 39 \\
\hline $12 / 12 / 02$ & 0.82 & 262 & 23.42 & 449 & 38 \\
\hline $12 / 13 / 02$ & 0.78 & 262 & 23.66 & 453 & 38 \\
\hline $12 / 14 / 02$ & 0.78 & 262 & 22.54 & 469 & 38 \\
\hline $12 / 15 / 02$ & 0.76 & 262 & 19.88 & 468 & 38 \\
\hline $12 / 16 / 02$ & 0.70 & 263 & 17.71 & 472 & 38 \\
\hline $12 / 17 / 02$ & 0.70 & 262 & 16.59 & 478 & 38 \\
\hline $12 / 18 / 02$ & 0.71 & 262 & 17.38 & 480 & 37 \\
\hline $12 / 19 / 02$ & 0.75 & 260 & 18.16 & 481 & 37 \\
\hline $12 / 20 / 02$ & 0.76 & 261 & 19.44 & 482 & 37 \\
\hline $12 / 21 / 02$ & 0.76 & 259 & 17.60 & 489 & 36 \\
\hline $12 / 22 / 02$ & 0.80 & 258 & 17.30 & 496 & 36 \\
\hline $12 / 23 / 02$ & 0.81 & 258 & 17.98 & 500 & 35 \\
\hline $12 / 24 / 02$ & 0.79 & 258 & 19.73 & 501 & 35 \\
\hline $12 / 25 / 02$ & 0.72 & 258 & 21.40 & 504 & 35 \\
\hline $12 / 26 / 02$ & 0.71 & 256 & 18.60 & 510 & 35 \\
\hline $12 / 27 / 02$ & 0.68 & 258 & 17.44 & 515 & 34 \\
\hline $12 / 28 / 02$ & 0.72 & 256 & 17.02 & 518 & 34 \\
\hline $12 / 29 / 02$ & 0.77 & 254 & 15.53 & 523 & 33 \\
\hline $12 / 30 / 02$ & 0.77 & 250 & 15.83 & 525 & 33 \\
\hline $12 / 31 / 02$ & 0.81 & 253 & 17.18 & 527 & 32 \\
\hline 01/01/03 & 0.83 & 252 & 19.53 & 529 & 32 \\
\hline 01/02/03 & 0.79 & 252 & 20.76 & 530 & 32 \\
\hline 01/03/03 & 0.77 & 253 & 21.02 & 519 & 33 \\
\hline
\end{tabular}


Table B - 4. Daily mean flow velocities, MicroCAT water temperatures and specific conductances, and water depths at station GS-203 during deployment period 12/04/02 1200-01/21/03 1330-Continued

\begin{tabular}{|c|c|c|c|c|c|}
\hline Date & $\begin{array}{l}\text { Flow velocity' } \\
\qquad(\mathrm{cm} / \mathrm{s})\end{array}$ & $\begin{array}{l}\text { Flow direction }{ }^{1} \\
\left({ }^{\circ} \mathrm{CW} \text { from } \mathrm{MN}\right)\end{array}$ & $\begin{array}{l}\text { Temperature } \\
\quad\left({ }^{\circ} \mathrm{C}\right)\end{array}$ & $\begin{array}{c}\text { Specific } \\
\text { conductance }^{2} \\
(\mu \mathrm{S} / \mathrm{cm})\end{array}$ & $\begin{array}{l}\text { Water depth } \\
\quad \text { (cm) }\end{array}$ \\
\hline $01 / 04 / 03$ & 0.74 & 250 & 17.53 & 518 & 33 \\
\hline $01 / 05 / 03$ & 0.65 & 248 & 16.21 & 514 & 32 \\
\hline $01 / 06 / 03$ & 0.60 & 248 & 16.48 & 513 & 32 \\
\hline $01 / 07 / 03$ & 0.59 & 246 & 15.52 & 514 & 32 \\
\hline $01 / 08 / 03$ & 0.56 & 247 & 14.90 & 519 & 31 \\
\hline $01 / 09 / 03$ & 0.42 & 246 & 14.73 & 522 & 31 \\
\hline 01/10/03 & 0.36 & 246 & 15.58 & 523 & 31 \\
\hline $01 / 11 / 03$ & 0.38 & 245 & 16.76 & 528 & 30 \\
\hline $01 / 12 / 03$ & 0.45 & 245 & 17.81 & 533 & 30 \\
\hline $01 / 13 / 03$ & 0.47 & 245 & 18.00 & 535 & 30 \\
\hline $01 / 14 / 03$ & 0.52 & 246 & 18.55 & 538 & 30 \\
\hline $01 / 15 / 03$ & 0.46 & 245 & 16.40 & 541 & 29 \\
\hline $01 / 16 / 03$ & 0.35 & 246 & 15.80 & 543 & 29 \\
\hline $01 / 17 / 03$ & 0.36 & 246 & 16.35 & 543 & 29 \\
\hline $01 / 18 / 03$ & 0.43 & 245 & 13.65 & 543 & 28 \\
\hline 01/19/03 & 0.32 & 244 & 11.53 & 550 & 28 \\
\hline 01/20/03 & 0.33 & 244 & 12.03 & 552 & 28 \\
\hline MINIMUM & 0.32 & 244 & 11.53 & 448 & 28 \\
\hline MAXIMUM & 0.94 & 264 & 23.66 & 552 & 40 \\
\hline AVERAGE & 0.67 & 254 & 18.25 & 506 & 34 \\
\hline $\begin{array}{l}\text { BURSTS } \\
\text { FILTERED } \\
\text { OUT }(\%)\end{array}$ & 0 & & & & \\
\hline
\end{tabular}

${ }^{1}$ Flow sample volume located $15 \mathrm{~cm}$ above top of litter.

${ }^{2}$ MicroCAT temperature and conductance measured $11 \mathrm{~cm}$ above top of litter.

${ }^{3}$ Depth variation determined from stage recorded at NP203 gage. 
Table B-5. Daily mean flow velocities, MicroCAT water temperatures and specific conductances, and water depths at station GS-203 during deployment period 01/23/03 1200-04/22/03 1400.

$\left[\mathrm{cm} / \mathrm{s}\right.$, centimeters per second; ${ }^{\circ} \mathrm{CW}$ from $\mathrm{MN}$, degrees clockwise from magnetic north; ${ }^{\circ} \mathrm{C}$, degrees Celsius; $\mu \mathrm{S} / \mathrm{cm}$ microsiemens per centimeter at 25 degrees Celsius; cm, centimeters; ${ }^{*}$, all bursts filtered out; - -, no data; \%, percent]

\begin{tabular}{|c|c|c|c|c|c|}
\hline Date & $\begin{array}{l}\text { Flow velocity }{ }^{1} \\
\text { (cm/s) }\end{array}$ & $\begin{array}{l}\text { Flow direction }{ }^{1} \\
\left({ }^{\circ} \mathrm{CW} \text { from MN) }\right.\end{array}$ & $\begin{array}{c}\text { Temperature } \\
\left({ }^{\circ} \mathrm{C}\right)\end{array}$ & $\begin{array}{c}\text { Specific } \\
\text { conductance }^{2} \\
(\mu \mathrm{S} / \mathrm{cm})\end{array}$ & $\begin{array}{l}\text { Water depth } \\
\text { (cm) }\end{array}$ \\
\hline $01 / 24 / 03$ & 0.74 & 246 & 12.09 & 556 & 27 \\
\hline $01 / 25 / 03$ & 0.68 & 246 & 11.15 & 560 & 26 \\
\hline $01 / 26 / 03$ & 0.67 & 245 & 13.14 & 560 & 26 \\
\hline $01 / 27 / 03$ & 0.68 & 243 & 14.23 & 560 & 26 \\
\hline $01 / 28 / 03$ & 0.69 & 243 & 13.52 & 561 & 25 \\
\hline $01 / 29 / 03$ & 0.69 & 245 & 14.88 & 561 & 25 \\
\hline $01 / 30 / 03$ & 0.70 & 246 & 16.16 & 562 & 25 \\
\hline $01 / 31 / 03$ & 0.74 & 245 & 17.59 & 563 & 25 \\
\hline 02/01/03 & 0.73 & 247 & 18.19 & 564 & 25 \\
\hline $02 / 02 / 03$ & 0.68 & 249 & 16.80 & 565 & 24 \\
\hline $02 / 03 / 03$ & 0.75 & 248 & 17.20 & 565 & 24 \\
\hline $02 / 04 / 03$ & 0.75 & 247 & 17.98 & 566 & 24 \\
\hline $02 / 05 / 03$ & 0.74 & 250 & 18.94 & 568 & 24 \\
\hline $02 / 06 / 03$ & 0.74 & 248 & 19.09 & 573 & 24 \\
\hline $02 / 07 / 03$ & 0.72 & 247 & 19.77 & 577 & 24 \\
\hline 02/08/03 & 0.67 & 245 & 20.92 & 578 & 23 \\
\hline 02/09/03 & 0.72 & 246 & 20.75 & 581 & 23 \\
\hline $02 / 10 / 03$ & 0.69 & 247 & 21.53 & 582 & 23 \\
\hline $02 / 11 / 03$ & 0.69 & 245 & 21.37 & 584 & 23 \\
\hline $02 / 12 / 03$ & 0.64 & 248 & 19.68 & 587 & 22 \\
\hline $02 / 13 / 03$ & 0.61 & 250 & 18.05 & 587 & 22 \\
\hline $02 / 14 / 03$ & 0.70 & 251 & 17.89 & 589 & 22 \\
\hline $02 / 15 / 03$ & 0.68 & 256 & 19.01 & 592 & 22 \\
\hline $02 / 16 / 03$ & 0.59 & 262 & 20.73 & 594 & 22 \\
\hline 02/17/03 & 0.62 & 256 & 21.48 & 590 & 22 \\
\hline 02/18/03 & 0.58 & 256 & 19.76 & 593 & 22 \\
\hline $02 / 19 / 03$ & 0.60 & 259 & 20.27 & 596 & 22 \\
\hline $02 / 20 / 03$ & 0.58 & 254 & 22.07 & 567 & 22 \\
\hline $02 / 21 / 03$ & 0.68 & 255 & 22.65 & 502 & 22 \\
\hline $02 / 22 / 03$ & 0.70 & 250 & 23.78 & 503 & 22 \\
\hline $02 / 23 / 03$ & 0.71 & 254 & 22.92 & 496 & 22 \\
\hline $02 / 24 / 03$ & 0.66 & 257 & 20.89 & 491 & 22 \\
\hline $02 / 25 / 03$ & 0.65 & 254 & 21.44 & 497 & 22 \\
\hline
\end{tabular}


Table B-5. Daily mean flow velocities, MicroCAT water temperatures and specific conductances, and water depths at station GS-203 during deployment period 01/23/03 1200-04/22/03 1400—Continued

\begin{tabular}{|c|c|c|c|c|c|}
\hline Date & $\begin{array}{l}\text { Flow velocity }{ }^{1} \\
\quad(\mathrm{~cm} / \mathrm{s})\end{array}$ & $\begin{array}{l}\text { Flow direction }{ }^{1} \\
\left({ }^{\circ} \mathrm{CW} \text { from MN) }\right.\end{array}$ & $\begin{array}{l}\text { Temperature }{ }^{2} \\
\left({ }^{\circ} \mathrm{C}\right)\end{array}$ & $\begin{array}{c}\text { Specific } \\
\text { conductance }{ }^{2} \\
(\mu \mathrm{S} / \mathrm{cm})\end{array}$ & $\begin{array}{l}\text { Water depth } \\
\quad \text { (cm) }\end{array}$ \\
\hline $02 / 26 / 03$ & 0.71 & 255 & 22.38 & 504 & 25 \\
\hline 02/27/03 & 0.67 & 252 & 23.33 & 503 & 26 \\
\hline $02 / 28 / 03$ & 0.60 & 244 & 24.06 & 493 & 26 \\
\hline 03/01/03 & 0.58 & 243 & 24.68 & 505 & 25 \\
\hline 03/02/03 & 0.62 & 245 & 24.98 & 509 & 25 \\
\hline 03/03/03 & 0.62 & 247 & 25.08 & 514 & 25 \\
\hline 03/04/03 & 0.56 & 246 & 25.63 & 522 & 24 \\
\hline 03/05/03 & 0.58 & 248 & 25.65 & 531 & 24 \\
\hline 03/06/03 & 0.56 & 246 & 25.38 & 537 & 23 \\
\hline 03/07/03 & 0.49 & 245 & 25.79 & 542 & 23 \\
\hline 03/08/03 & 0.53 & 240 & 25.77 & 545 & 22 \\
\hline 03/09/03 & 0.45 & 234 & 26.03 & 536 & 23 \\
\hline 03/10/03 & 0.44 & 235 & 25.32 & 538 & 23 \\
\hline 03/11/03 & 0.44 & 230 & 25.28 & 536 & 22 \\
\hline 03/12/03 & 0.44 & 233 & 25.35 & 539 & 22 \\
\hline 03/13/03 & 0.46 & 231 & 25.59 & 544 & 22 \\
\hline 03/14/03 & 0.49 & 236 & 25.70 & 548 & 21 \\
\hline 03/15/03 & 0.45 & 230 & 25.83 & 552 & 21 \\
\hline 03/16/03 & 0.47 & 230 & 25.03 & 557 & 20 \\
\hline 03/17/03 & 0.39 & 230 & 24.47 & 525 & 22 \\
\hline 03/18/03 & 0.40 & 231 & 24.42 & 524 & 22 \\
\hline 03/19/03 & 0.40 & 223 & 26.20 & 531 & 22 \\
\hline 03/20/03 & 0.43 & 226 & 26.83 & 536 & 21 \\
\hline 03/21/03 & 0.42 & 223 & 26.98 & 526 & 21 \\
\hline 03/22/03 & 0.47 & 229 & 27.24 & 533 & 21 \\
\hline 03/23/03 & 0.45 & 225 & 26.67 & 539 & 20 \\
\hline 03/24/03 & 0.49 & 230 & 25.08 & 545 & 20 \\
\hline 03/25/03 & 0.49 & 233 & 23.08 & 556 & 19 \\
\hline 03/26/03 & 0.57 & 234 & 23.21 & 566 & 19 \\
\hline $03 / 27 / 03$ & 0.61 & 235 & 23.12 & 556 & 19 \\
\hline 03/28/03 & 0.64 & 229 & 23.65 & 538 & 21 \\
\hline 03/29/03 & 0.64 & 229 & 24.33 & 536 & 21 \\
\hline 03/30/03 & 0.65 & 231 & 23.75 & 533 & 20 \\
\hline
\end{tabular}


Table B-5. Daily mean flow velocities, MicroCAT water temperatures and specific conductances, and water depths at station GS-203 during deployment period 01/23/03 1200-04/22/03 1400_Continued

\begin{tabular}{|c|c|c|c|c|c|}
\hline Date & $\begin{array}{l}\text { Flow velocity } \\
\quad(\mathrm{cm} / \mathrm{s})\end{array}$ & $\begin{array}{l}\text { Flow direction }{ }^{1} \\
\left({ }^{\circ} \mathrm{CW} \text { from } \mathrm{MN}\right)\end{array}$ & $\begin{array}{c}\text { Temperature }^{2} \\
\left({ }^{\circ} \mathrm{C}\right)\end{array}$ & 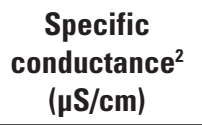 & $\begin{array}{l}\text { Water depth } \\
\text { (cm) }\end{array}$ \\
\hline 03/31/03 & 0.62 & 231 & 19.21 & 545 & 20 \\
\hline $04 / 01 / 03$ & 0.64 & 232 & 17.16 & 559 & 19 \\
\hline $04 / 02 / 03$ & 0.62 & 231 & 18.98 & 571 & 19 \\
\hline 04/03/03 & 0.64 & 234 & 20.54 & 572 & 19 \\
\hline 04/04/03 & 0.64 & 236 & 21.85 & 571 & -- \\
\hline 04/05/03 & 0.67 & 237 & 22.53 & 570 & -- \\
\hline 04/06/03 & 0.72 & 239 & 23.86 & 569 & -- \\
\hline 04/07/03 & 0.67 & 240 & 25.11 & 570 & -- \\
\hline 04/08/03 & 0.62 & 243 & 25.46 & 571 & -- \\
\hline 04/09/03 & 0.66 & 242 & 24.62 & 574 & -- \\
\hline 04/10/03 & 0.62 & 247 & 22.15 & 578 & -- \\
\hline $04 / 11 / 03$ & $*$ & $*$ & 20.85 & 585 & -- \\
\hline $04 / 12 / 03$ & * & * & 21.10 & 593 & -- \\
\hline 04/13/03 & $*$ & $*$ & 21.80 & 598 & -- \\
\hline $04 / 14 / 03$ & $*$ & $*$ & 22.14 & 601 & -- \\
\hline $04 / 15 / 03$ & * & * & 23.57 & 602 & -- \\
\hline $04 / 16 / 03$ & $*$ & $*$ & 24.16 & 601 & -- \\
\hline 04/17/03 & 0.82 & 239 & 24.99 & 557 & -- \\
\hline 04/18/03 & 0.61 & 235 & 25.09 & 461 & -- \\
\hline 04/19/03 & 0.57 & 236 & 25.40 & 430 & -- \\
\hline $04 / 20 / 03$ & 0.53 & 237 & 25.33 & 419 & -- \\
\hline $04 / 21 / 03$ & 0.51 & 237 & 25.39 & 399 & 22 \\
\hline MINIMUM & 0.39 & 223 & 11.15 & 399 & 19 \\
\hline MAXIMUM & 0.82 & 262 & 27.24 & 602 & 27 \\
\hline AVERAGE & 0.61 & 242 & 22.08 & 548 & 23 \\
\hline $\begin{array}{l}\text { BURSTS } \\
\text { FILTERED } \\
\text { OUT }(\%)\end{array}$ & 13 & & & & \\
\hline
\end{tabular}

${ }^{1}$ Flow sample volume located $15 \mathrm{~cm}$ above top of litter.

${ }^{2}$ MicroCAT temperature and conductance measured $11 \mathrm{~cm}$ above top of litter.

${ }^{3}$ Depth variation determined from stage recorded at NP203 gage. 
Appendix C. Daily mean flow velocities, water temperatures, specific conductances, and water depths at station GS-33, Shark River Slough, Everglades National Park, Florida during the 2002-2003 wet season. 
Table C - 1. Daily mean flow velocities, MicroCAT water temperatures and specific conductances, and water depths at station GS-33 during deployment period 06/27/02 1200-08/27/02 1500.

$\left[\mathrm{cm} / \mathrm{s}\right.$, centimeters per second; ${ }^{\circ} \mathrm{CW}$ from $\mathrm{MN}$, degrees clockwise from magnetic north; ${ }^{\circ} \mathrm{C}$, degrees Celsius; $\mu \mathrm{S} / \mathrm{cm}$ microsiemens per centimeter at 25 degrees Celsius; $\mathrm{cm}$, centimeters; --, no data; \%, percent]

\begin{tabular}{|c|c|c|c|c|c|}
\hline Date & $\begin{array}{l}\text { Flow velocity } \\
\text { (cm/s) }\end{array}$ & $\begin{array}{l}\text { Flow direction }{ }^{1} \\
\text { ( }{ }^{\circ} \mathrm{CW} \text { from MN) }\end{array}$ & $\begin{array}{c}\text { Temperature }^{2} \\
\left({ }^{\circ} \mathrm{C}\right)\end{array}$ & $\begin{array}{c}\text { Specific } \\
\text { conductance }^{2} \\
(\mu \mathrm{S} / \mathrm{cm})\end{array}$ & $\begin{array}{l}\text { Water depth } \\
\text { (cm) }\end{array}$ \\
\hline 06/28/02 & 0.44 & 190 & 27.90 & 278 & 36 \\
\hline 06/29/02 & 0.46 & 192 & 28.97 & 295 & 35 \\
\hline 06/30/02 & 0.56 & 198 & 29.31 & 310 & 34 \\
\hline 07/01/02 & 0.52 & 196 & 28.42 & 316 & 34 \\
\hline 07/02/02 & 0.54 & 194 & 28.44 & 324 & 33 \\
\hline 07/03/02 & 0.56 & 196 & 29.78 & 330 & 33 \\
\hline 07/04/02 & 0.55 & 199 & 30.58 & 334 & 33 \\
\hline 07/05/02 & 0.53 & 203 & 30.59 & 336 & 33 \\
\hline 07/06/02 & 0.52 & 201 & 28.84 & 325 & 34 \\
\hline 07/07/02 & 0.49 & 193 & 28.95 & 309 & 34 \\
\hline 07/08/02 & 0.43 & 197 & 27.82 & 311 & 35 \\
\hline 07/09/02 & 0.46 & 191 & 27.01 & 290 & 37 \\
\hline 07/10/02 & 0.49 & 192 & 26.84 & 290 & 38 \\
\hline $07 / 11 / 02$ & 0.53 & 195 & 26.90 & 281 & 40 \\
\hline 07/12/02 & 0.54 & 186 & 28.56 & 280 & 40 \\
\hline 07/13/02 & 0.58 & 180 & 30.35 & 283 & 41 \\
\hline 07/14/02 & 0.58 & 180 & 31.89 & 285 & 41 \\
\hline 07/15/02 & 0.54 & 180 & 32.48 & 294 & 40 \\
\hline 07/16/02 & 0.68 & 182 & 31.31 & 301 & 41 \\
\hline 07/17/02 & 0.64 & 182 & 31.28 & 292 & 42 \\
\hline 07/18/02 & 0.56 & 179 & 31.25 & 305 & 41 \\
\hline 07/19/02 & 0.53 & 190 & 30.69 & 293 & 42 \\
\hline 07/20/02 & 0.58 & 188 & 31.38 & 312 & 41 \\
\hline $07 / 21 / 02$ & 0.56 & 194 & 31.64 & 335 & 41 \\
\hline $07 / 22 / 02$ & 0.53 & 190 & 30.88 & 349 & 40 \\
\hline 07/23/02 & 0.61 & 188 & 30.52 & 364 & 40 \\
\hline 07/24/02 & 0.55 & 183 & 29.99 & 362 & 39 \\
\hline $07 / 25 / 02$ & 0.54 & 184 & 30.25 & 354 & 39 \\
\hline 07/26/02 & 0.50 & 192 & 30.94 & 351 & 39 \\
\hline 07/27/02 & 0.50 & 197 & 31.42 & 348 & 39 \\
\hline 07/28/02 & 0.47 & 201 & 31.38 & 346 & 39 \\
\hline 07/29/02 & 0.49 & 201 & 31.00 & 344 & 39 \\
\hline 07/30/02 & 0.43 & 205 & 30.87 & 336 & 39 \\
\hline
\end{tabular}


Table C - 1. Daily mean flow velocities, MicroCAT water temperatures and specific conductances, and water depths at station GS-33 during deployment period 06/27/02 1200- 08/27/02 1500 — Continued

\begin{tabular}{|c|c|c|c|c|c|}
\hline Date & $\begin{array}{l}\text { Flow velocity' } \\
\quad(\mathrm{cm} / \mathrm{s})\end{array}$ & $\begin{array}{l}\text { Flow direction }{ }^{1} \\
\left({ }^{\circ} \mathrm{CW} \text { from } \mathrm{MN}\right)\end{array}$ & $\begin{array}{l}\text { Temperature }{ }^{2} \\
\left({ }^{\circ} \mathrm{C}\right)\end{array}$ & $\begin{array}{c}\text { Specific } \\
\text { conductance } \\
(\mu \mathrm{S} / \mathrm{cm})\end{array}$ & $\begin{array}{l}\text { Water depth } \\
\quad \text { (cm) }\end{array}$ \\
\hline 07/31/02 & 0.46 & 204 & 31.31 & 343 & 39 \\
\hline 08/01/02 & 0.42 & 201 & 31.30 & 354 & 38 \\
\hline 08/02/02 & 0.49 & 208 & 31.68 & 370 & 38 \\
\hline 08/03/02 & 0.51 & 201 & 31.78 & 385 & 38 \\
\hline 08/04/02 & 0.44 & 197 & 31.44 & 402 & 39 \\
\hline 08/05/02 & 0.49 & 200 & 31.04 & 409 & 39 \\
\hline 08/06/02 & 0.42 & 189 & 31.19 & 422 & 40 \\
\hline 08/07/02 & 0.43 & 184 & 30.65 & 431 & 40 \\
\hline 08/08/02 & 0.67 & 171 & 29.68 & 445 & 40 \\
\hline 08/09/02 & 0.76 & 158 & 30.23 & 451 & 41 \\
\hline 08/10/02 & 0.82 & 159 & 29.46 & 468 & 40 \\
\hline 08/11/02 & 0.87 & 164 & 28.16 & 466 & 40 \\
\hline 08/12/02 & 1.11 & 163 & 27.86 & 445 & 44 \\
\hline 08/13/02 & 1.11 & 164 & 29.19 & 463 & 44 \\
\hline 08/14/02 & 1.04 & 166 & 29.42 & 481 & 43 \\
\hline 08/15/02 & 1.04 & 165 & 29.96 & 481 & 43 \\
\hline 08/16/02 & 0.49 & 149 & 29.99 & 487 & 43 \\
\hline 08/17/02 & 0.59 & 153 & 30.25 & 496 & 43 \\
\hline 08/18/02 & 0.71 & 157 & 30.96 & 509 & 43 \\
\hline 08/19/02 & 0.84 & 155 & 30.52 & 519 & 43 \\
\hline 08/20/02 & 0.71 & 165 & 29.85 & 528 & 43 \\
\hline $08 / 21 / 02$ & 0.26 & 159 & 28.74 & 525 & 43 \\
\hline $08 / 22 / 02$ & 0.30 & 171 & 29.56 & 529 & 44 \\
\hline $08 / 23 / 02$ & 0.37 & 180 & 30.17 & 542 & - - \\
\hline $08 / 24 / 02$ & 0.81 & 181 & 29.96 & 555 & - - \\
\hline $08 / 25 / 02$ & 1.03 & 168 & 30.05 & 564 & 44 \\
\hline 08/26/02 & 1.03 & 170 & 30.66 & 571 & 43 \\
\hline MINIMUM & 0.26 & 149 & 26.84 & 278 & 33 \\
\hline MAXIMUM & 1.11 & 208 & 32.48 & 571 & 44 \\
\hline AVERAGE & 0.60 & 184 & 30.06 & 385 & 39 \\
\hline $\begin{array}{l}\text { BURSTS } \\
\text { FILTERED } \\
\text { OUT }(\%)\end{array}$ & 1 & & & & \\
\hline
\end{tabular}

${ }^{1}$ Flow sample volume located $19 \mathrm{~cm}$ above top of litter.

${ }^{2}$ MicroCAT temperature and conductance measured $17 \mathrm{~cm}$ above top of litter.

${ }^{3}$ Depth variation determined from stage recorded at P33 gage. 
Table C-2. Daily mean flow velocities, MicroCAT water temperatures and specific conductances, and water depths at station GS-33 during deployment period 08/28/02 1400-10/29/02 1600.

$\left[\mathrm{cm} / \mathrm{s}\right.$, centimeters per second; ${ }^{\circ} \mathrm{CW}$ from $\mathrm{MN}$, degrees clockwise from magnetic north; ${ }^{\circ} \mathrm{C}$, degrees Celsius; $\mu \mathrm{S} / \mathrm{cm}$ microsiemens per centimeter at 25 degrees Celsius; cm, centimeters; --, no data; \%, percent]

\begin{tabular}{|c|c|c|c|c|c|}
\hline Date & $\begin{array}{l}\text { Flow velocity } \\
\quad(\mathrm{cm} / \mathrm{s})\end{array}$ & $\begin{array}{l}\text { Flow direction } \\
\left({ }^{\circ} \mathrm{CW} \text { from } \mathrm{MN}\right)\end{array}$ & $\begin{array}{l}\text { Temperature }^{2} \\
\left({ }^{\circ} \mathrm{C}\right)\end{array}$ & $\begin{array}{c}\text { Specific } \\
\text { conductance } \\
(\mu \mathrm{S} / \mathrm{cm})\end{array}$ & $\begin{array}{l}\text { Water depth } \\
\quad \text { (cm) }\end{array}$ \\
\hline $08 / 29 / 02$ & 0.67 & 184 & 28.42 & 542 & 46 \\
\hline 08/30/02 & 0.75 & 179 & 28.34 & 550 & 46 \\
\hline $08 / 31 / 02$ & 0.76 & 180 & 28.60 & 554 & - \\
\hline 09/01/02 & 0.73 & 182 & 29.36 & 554 & -- \\
\hline 09/02/02 & 0.76 & 187 & 29.48 & 537 & 47 \\
\hline 09/03/02 & 0.82 & 182 & 29.20 & 497 & -- \\
\hline 09/04/02 & 0.80 & 182 & 29.09 & 471 & - - \\
\hline 09/05/02 & 0.80 & 182 & 29.41 & 472 & -- \\
\hline 09/06/02 & 0.73 & 186 & 29.07 & 472 & -- \\
\hline 09/07/02 & 0.68 & 187 & 29.56 & 473 & -- \\
\hline 09/08/02 & 0.58 & 186 & 29.51 & 480 & - - \\
\hline 09/09/02 & 0.62 & 181 & 29.65 & 485 & -- \\
\hline 09/10/02 & 0.65 & 175 & 29.71 & 491 & -- \\
\hline 09/11/02 & 0.55 & 182 & 28.61 & 498 & -- \\
\hline 09/12/02 & 0.60 & 177 & 27.18 & 491 & -- \\
\hline 09/13/02 & 0.60 & 177 & 27.82 & 486 & -- \\
\hline 09/14/02 & 0.58 & 180 & 28.92 & 476 & -- \\
\hline 09/15/02 & 0.57 & 184 & 29.75 & 474 & -- \\
\hline 09/16/02 & 0.64 & 183 & 29.79 & 475 & -- \\
\hline 09/17/02 & 0.64 & 188 & 30.27 & 477 & -- \\
\hline 09/18/02 & 0.59 & 192 & 30.55 & 479 & -- \\
\hline 09/19/02 & 0.82 & 197 & 30.41 & 483 & -- \\
\hline 09/20/02 & 0.49 & 199 & 30.08 & 482 & -- \\
\hline 09/21/02 & 0.53 & 198 & 29.54 & 485 & -- \\
\hline 09/22/02 & 0.51 & 196 & 29.53 & 491 & -- \\
\hline 09/23/02 & 0.48 & 208 & 28.52 & 482 & -- \\
\hline $09 / 24 / 02$ & 0.50 & 216 & 28.14 & 455 & - - \\
\hline $09 / 25 / 02$ & 0.70 & 212 & 29.10 & 452 & 50 \\
\hline 09/26/02 & 0.78 & 204 & 29.28 & 453 & 50 \\
\hline 09/27/02 & 0.81 & 197 & 29.72 & 449 & 49 \\
\hline $09 / 28 / 02$ & 0.78 & 194 & 29.64 & 435 & 49 \\
\hline 09/29/02 & 0.76 & 194 & 29.67 & 435 & 49 \\
\hline 09/30/02 & 0.73 & 198 & 29.31 & 438 & 49 \\
\hline $10 / 01 / 02$ & 0.74 & 199 & 29.39 & 442 & 48 \\
\hline
\end{tabular}


Table C-2. Daily mean flow velocities, MicroCAT water temperatures and specific conductances, and water depths at station GS-33 during deployment period 08/28/02 1400-10/29/02 1600—Continued

\begin{tabular}{|c|c|c|c|c|c|}
\hline Date & $\begin{array}{l}\text { Flow velocity }{ }^{1} \\
\quad(\mathrm{~cm} / \mathrm{s})\end{array}$ & $\begin{array}{l}\text { Flow direction }{ }^{1} \\
\left({ }^{\circ} \mathrm{CW} \text { from } \mathrm{MN}\right)\end{array}$ & $\begin{array}{l}\text { Temperature }^{2} \\
\left({ }^{\circ} \mathrm{C}\right)\end{array}$ & $\begin{array}{c}\text { Specific } \\
\text { conductance } \\
(\mu \mathrm{S} / \mathrm{cm})\end{array}$ & $\begin{array}{l}\text { Water depth } \\
\text { (cm) }\end{array}$ \\
\hline $10 / 02 / 02$ & 0.69 & 199 & 29.46 & 447 & 47 \\
\hline $10 / 03 / 02$ & 0.62 & 198 & 29.34 & 451 & 47 \\
\hline $10 / 04 / 02$ & 0.61 & 200 & 28.58 & 455 & 47 \\
\hline $10 / 05 / 02$ & 0.65 & 197 & 28.64 & 454 & 47 \\
\hline $10 / 06 / 02$ & 0.69 & 194 & 28.31 & 452 & 47 \\
\hline $10 / 07 / 02$ & 0.68 & 195 & 28.08 & 457 & 47 \\
\hline $10 / 08 / 02$ & 0.72 & 195 & 28.27 & 460 & 46 \\
\hline $10 / 09 / 02$ & 0.79 & 194 & 27.85 & 467 & 46 \\
\hline 10/10/02 & 0.75 & 195 & 28.09 & 474 & 45 \\
\hline 10/11/02 & 0.82 & 191 & 28.21 & 483 & 46 \\
\hline $10 / 12 / 02$ & 0.89 & 191 & 28.19 & 495 & 46 \\
\hline $10 / 13 / 02$ & 0.81 & 194 & 28.63 & 503 & 46 \\
\hline $10 / 14 / 02$ & 0.67 & 194 & 28.34 & 512 & 46 \\
\hline $10 / 15 / 02$ & 0.62 & 195 & 28.02 & 518 & 46 \\
\hline $10 / 16 / 02$ & 0.68 & 194 & 27.74 & 514 & 47 \\
\hline $10 / 17 / 02$ & 0.68 & 194 & 26.87 & 514 & 47 \\
\hline 10/18/02 & 0.70 & 194 & 25.80 & 523 & 47 \\
\hline $10 / 19 / 02$ & 0.65 & 195 & 25.60 & 526 & 46 \\
\hline $10 / 20 / 02$ & 0.72 & 198 & 26.19 & 522 & 47 \\
\hline $10 / 21 / 02$ & 0.85 & 196 & 26.17 & 510 & 47 \\
\hline $10 / 22 / 02$ & 0.65 & 194 & 26.32 & 514 & 47 \\
\hline $10 / 23 / 02$ & 0.50 & 190 & 27.34 & 520 & 47 \\
\hline $10 / 24 / 02$ & 0.41 & 199 & 27.60 & 528 & 46 \\
\hline $10 / 25 / 02$ & 0.44 & 207 & 27.62 & 528 & 46 \\
\hline $10 / 26 / 02$ & 0.47 & 207 & 27.41 & 532 & 46 \\
\hline $10 / 27 / 02$ & 0.58 & 206 & 27.58 & 524 & 46 \\
\hline 10/28/02 & 0.60 & 203 & 27.73 & 523 & 45 \\
\hline MINIMUM & 0.41 & 175 & 25.60 & 435 & 45 \\
\hline MAXIMUM & 0.89 & 216 & 30.55 & 554 & 50 \\
\hline AVERAGE & 0.67 & 193 & 28.57 & 489 & 47 \\
\hline $\begin{array}{l}\text { BURSTS } \\
\text { FILTERED } \\
\text { OUT }(\%)\end{array}$ & 0 & & & & \\
\hline
\end{tabular}

${ }^{1}$ Flow sample volume located $19 \mathrm{~cm}$ above top of litter.

${ }^{2}$ MicroCAT temperature and conductance measured $17 \mathrm{~cm}$ above top of litter.

${ }^{3}$ Depth variation determined from stage recorded at P33 gage. 
Table C - 3. Daily mean flow velocities, MicroCAT water temperatures and specific conductances, and water depths at station GS-33 during deployment period 10/30/02 1400-12/03/02 1400.

$\left[\mathrm{cm} / \mathrm{s}\right.$, centimeters per second; ${ }^{\circ} \mathrm{CW}$ from $\mathrm{MN}$, degrees clockwise from magnetic north; ${ }^{\circ} \mathrm{C}$, degrees Celsius; $\mu \mathrm{S} / \mathrm{cm}$ microsiemens per centimeters at 25 degrees Celsius; cm, centimeter; $*$, all bursts filtered out; \%, percent]

\begin{tabular}{|c|c|c|c|c|c|}
\hline Date & $\begin{array}{l}\text { Flow velocity }{ }^{1} \\
\qquad(\mathrm{~cm} / \mathrm{s})\end{array}$ & $\begin{array}{l}\text { Flow direction }{ }^{1} \\
\left({ }^{\circ} \mathrm{CW} \text { from MN) }\right.\end{array}$ & $\begin{array}{c}\text { Temperature } \\
\left({ }^{\circ} \mathrm{C}\right)\end{array}$ & 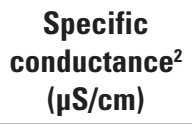 & $\begin{array}{l}\text { Water depth } \\
\text { (cm) }\end{array}$ \\
\hline $10 / 31 / 02$ & 0.76 & 202 & 27.87 & 538 & 44 \\
\hline $11 / 01 / 02$ & 0.75 & 207 & 27.79 & 542 & 44 \\
\hline $11 / 02 / 02$ & 0.77 & 210 & 27.02 & 547 & 43 \\
\hline $11 / 03 / 02$ & 0.80 & 209 & 26.00 & 552 & 43 \\
\hline $11 / 04 / 02$ & 0.74 & 211 & 25.68 & 558 & 43 \\
\hline $11 / 05 / 02$ & 0.78 & 209 & 25.91 & 564 & 42 \\
\hline $11 / 06 / 02$ & 0.80 & 208 & 26.41 & 568 & 42 \\
\hline $11 / 07 / 02$ & 0.78 & 211 & 24.10 & 570 & 42 \\
\hline $11 / 08 / 02$ & 0.75 & 210 & 22.57 & 568 & 41 \\
\hline $11 / 09 / 02$ & 0.69 & 212 & 23.10 & 568 & 41 \\
\hline $11 / 10 / 02$ & 0.68 & 209 & 23.62 & 572 & 41 \\
\hline $11 / 11 / 02$ & 0.68 & 212 & 24.22 & 577 & 41 \\
\hline $11 / 12 / 02$ & 0.66 & 210 & 25.33 & 582 & 41 \\
\hline $11 / 13 / 02$ & 0.63 & 215 & 24.43 & 583 & 41 \\
\hline $11 / 14 / 02$ & 0.64 & 213 & 21.31 & 588 & 40 \\
\hline $11 / 15 / 02$ & 0.62 & 211 & 22.26 & 592 & 40 \\
\hline $11 / 16 / 02$ & 0.64 & 209 & 22.89 & 585 & 41 \\
\hline $11 / 17 / 02$ & 0.68 & 206 & 22.07 & 490 & 47 \\
\hline $11 / 18 / 02$ & 0.63 & 210 & 18.88 & 505 & 46 \\
\hline $11 / 19 / 02$ & 0.64 & 214 & 18.97 & 498 & 45 \\
\hline $11 / 20 / 02$ & $*$ & $*$ & 20.44 & 505 & 44 \\
\hline
\end{tabular}


Table C - 3. Daily mean flow velocities, MicroCAT water temperatures and specific conductances, and water depths at station GS-33 during deployment period 10/30/02 1400-12/03/02 1400—Continued

\begin{tabular}{|c|c|c|c|c|c|}
\hline Date & $\begin{array}{l}\text { Flow velocity' } \\
\text { (cm/s) }\end{array}$ & $\begin{array}{l}\text { Flow direction }{ }^{1} \\
\left({ }^{\circ} \mathrm{CW} \text { from MN) }\right.\end{array}$ & $\begin{array}{l}\text { Temperature }{ }^{2} \\
\left({ }^{\circ} \mathrm{C}\right)\end{array}$ & $\begin{array}{c}\text { Specific } \\
\text { conductance } \\
(\mu \mathrm{S} / \mathrm{cm})\end{array}$ & $\begin{array}{l}\text { Water depth } \\
\quad \text { (cm) }\end{array}$ \\
\hline $11 / 21 / 02$ & 0.46 & 215 & 21.95 & 507 & 44 \\
\hline $11 / 22 / 02$ & 0.47 & 219 & 22.51 & 518 & 43 \\
\hline $11 / 23 / 02$ & 0.53 & 223 & 20.54 & 530 & 42 \\
\hline $11 / 24 / 02$ & 0.52 & 223 & 19.11 & 536 & 41 \\
\hline $11 / 25 / 02$ & 0.61 & 227 & 20.37 & 531 & 41 \\
\hline $11 / 26 / 02$ & 0.61 & 225 & 21.70 & 530 & 40 \\
\hline $11 / 27 / 02$ & 0.65 & 227 & 21.34 & 528 & 39 \\
\hline $11 / 28 / 02$ & 0.63 & 226 & 20.69 & 528 & 39 \\
\hline $11 / 29 / 02$ & 0.59 & 224 & 19.13 & 534 & 38 \\
\hline $11 / 30 / 02$ & 0.61 & 224 & 17.93 & 537 & 37 \\
\hline $12 / 01 / 02$ & 0.62 & 227 & 18.30 & 541 & 37 \\
\hline $12 / 02 / 02$ & 0.49 & 223 & 19.68 & 546 & 36 \\
\hline MINIMUM & 0.46 & 202 & 17.93 & 490 & 36 \\
\hline MAXIMUM & 0.80 & 227 & 27.87 & 592 & 47 \\
\hline AVERAGE & 0.65 & 215 & 22.55 & 546 & 41 \\
\hline $\begin{array}{l}\text { BURSTS } \\
\text { FILTERED } \\
\text { OUT }(\%)\end{array}$ & 6 & & & & \\
\hline
\end{tabular}

${ }^{1}$ Flow sample volume located $19 \mathrm{~cm}$ above top of litter.

${ }^{2}$ MicroCAT temperature and conductance measured $17 \mathrm{~cm}$ above top of litter.

${ }^{3}$ Depth variation determined from stage recorded at P33 gage. 
Table C - 4. Daily mean flow velocities, MicroCAT water temperatures and specific conductances, and water depths at station GS-33 during deployment period 12/04/02 1400-01/21/03 1430.

$\left[\mathrm{cm} / \mathrm{s}\right.$, centimeters per second; ${ }^{\circ} \mathrm{CW}$ from $\mathrm{MN}$, degrees clockwise from magnetic north; ${ }^{\circ} \mathrm{C}$, degrees Celsius; $\mu \mathrm{S} / \mathrm{cm}$ microsiemens per centimeter at 25 degrees Celsius; cm, centimeters; *, all bursts filtered out; \%, percent]

\begin{tabular}{|c|c|c|c|c|c|}
\hline Date & $\begin{array}{l}\text { Flow velocity } \\
\qquad(\mathrm{cm} / \mathrm{s})\end{array}$ & $\begin{array}{l}\text { Flow direction }{ }^{1} \\
\text { ( }{ }^{\circ} \mathrm{CW} \text { from MN) }\end{array}$ & $\begin{array}{c}\text { Temperature }^{2} \\
\left({ }^{\circ} \mathrm{C}\right)\end{array}$ & $\begin{array}{c}\text { Specific } \\
\text { conductance }^{2} \\
(\mu \mathrm{S} / \mathrm{cm})\end{array}$ & $\begin{array}{l}\text { Water depth } \\
\text { (cm) }\end{array}$ \\
\hline $12 / 05 / 02$ & 0.70 & 214 & 22.17 & 555 & 34 \\
\hline $12 / 06 / 02$ & 0.69 & 217 & 23.00 & 560 & 34 \\
\hline $12 / 07 / 02$ & 0.66 & 215 & 21.19 & 565 & 34 \\
\hline $12 / 08 / 02$ & 0.62 & 208 & 21.56 & 566 & 33 \\
\hline $12 / 09 / 02$ & 0.66 & 215 & 21.85 & 546 & 35 \\
\hline $12 / 10 / 02$ & 0.80 & 218 & 22.36 & 475 & 39 \\
\hline $12 / 11 / 02$ & 0.84 & 220 & 22.94 & 486 & 39 \\
\hline $12 / 12 / 02$ & 0.87 & 219 & 23.65 & 491 & 39 \\
\hline $12 / 13 / 02$ & 0.85 & 220 & 23.78 & 505 & 38 \\
\hline $12 / 14 / 02$ & 0.79 & 217 & 22.51 & 505 & 38 \\
\hline $12 / 15 / 02$ & 0.79 & 219 & 19.61 & 507 & 37 \\
\hline $12 / 16 / 02$ & 0.75 & 220 & 17.49 & 508 & 36 \\
\hline $12 / 17 / 02$ & 0.78 & 225 & 16.22 & 514 & 36 \\
\hline $12 / 18 / 02$ & 0.80 & 225 & 17.20 & 518 & 35 \\
\hline $12 / 19 / 02$ & 0.87 & 224 & 18.12 & 523 & 35 \\
\hline $12 / 20 / 02$ & 0.84 & 223 & 19.58 & 527 & 34 \\
\hline $12 / 21 / 02$ & 0.81 & 218 & 17.56 & 536 & 34 \\
\hline $12 / 22 / 02$ & 0.81 & 223 & 17.39 & 546 & 33 \\
\hline $12 / 23 / 02$ & 0.86 & 222 & 18.05 & 553 & 33 \\
\hline $12 / 24 / 02$ & 0.87 & 224 & 20.26 & 555 & 32 \\
\hline $12 / 25 / 02$ & 0.83 & 227 & 21.90 & 552 & 32 \\
\hline $12 / 26 / 02$ & 0.78 & 227 & 18.55 & 551 & 32 \\
\hline $12 / 27 / 02$ & 0.82 & 226 & 17.39 & 556 & 32 \\
\hline $12 / 28 / 02$ & 0.78 & 224 & 17.16 & 553 & 31 \\
\hline $12 / 29 / 02$ & 0.78 & 224 & 15.64 & 551 & 31 \\
\hline $12 / 30 / 02$ & 0.76 & 223 & 16.11 & 549 & 31 \\
\hline $12 / 31 / 02$ & 0.76 & 221 & 17.80 & 549 & 30 \\
\hline 01/01/03 & 0.78 & 222 & 20.58 & 548 & 30 \\
\hline
\end{tabular}


Table C - 4. Daily mean flow velocities, MicroCAT water temperatures and specific conductances, and water depths at station GS-33 during deployment period 12/04/02 1400-01/21/03 1430—Continued

\begin{tabular}{|c|c|c|c|c|c|}
\hline Date & $\begin{array}{l}\text { Flow velocity }{ }^{1} \\
\quad(\mathrm{~cm} / \mathrm{s})\end{array}$ & $\begin{array}{l}\text { Flow direction }{ }^{1} \\
\left({ }^{\circ} \mathrm{CW} \text { from MN) }\right.\end{array}$ & $\begin{array}{c}\text { Temperature } \\
\left({ }^{\circ} \mathrm{C}\right)\end{array}$ & $\begin{array}{c}\text { Specific } \\
\text { conductance }^{2} \\
(\mu \mathrm{S} / \mathrm{cm})\end{array}$ & $\begin{array}{l}\text { Water depth } \\
\text { (cm) }\end{array}$ \\
\hline 01/02/03 & 0.74 & 223 & 21.51 & 552 & 30 \\
\hline 01/03/03 & 0.65 & 224 & 21.12 & 534 & 31 \\
\hline 01/04/03 & 0.73 & 220 & 17.40 & 537 & 31 \\
\hline 01/05/03 & 0.72 & 224 & 16.22 & 541 & 30 \\
\hline 01/06/03 & 0.71 & 222 & 16.69 & 545 & 30 \\
\hline 01/07/03 & 0.72 & 218 & 15.61 & 555 & 30 \\
\hline 01/08/03 & 0.74 & 220 & 15.24 & 563 & 29 \\
\hline 01/09/03 & 0.74 & 220 & 15.08 & 571 & 29 \\
\hline 01/10/03 & 0.72 & 220 & 15.86 & 578 & 29 \\
\hline 01/11/03 & 0.69 & 217 & 17.24 & 585 & 28 \\
\hline 01/12/03 & 0.74 & 221 & 18.35 & 590 & 28 \\
\hline 01/13/03 & 0.79 & 222 & 18.49 & 597 & 28 \\
\hline 01/14/03 & 0.76 & 227 & 19.07 & 602 & 28 \\
\hline 01/15/03 & 0.75 & 228 & 16.78 & 608 & 27 \\
\hline 01/16/03 & 0.67 & 238 & 16.20 & 614 & 27 \\
\hline 01/17/03 & $*$ & $*$ & 16.89 & 615 & 27 \\
\hline 01/18/03 & $*$ & $*$ & 13.46 & 621 & 27 \\
\hline 01/19/03 & 0.80 & 222 & 12.03 & 630 & 26 \\
\hline $01 / 20 / 03$ & 0.69 & 222 & 12.56 & 633 & 26 \\
\hline MINIMUM & 0.62 & 208 & 12.03 & 475 & 26 \\
\hline MAXIMUM & 0.87 & 238 & 23.78 & 633 & 39 \\
\hline AVERAGE & 0.76 & 221 & 18.46 & 554 & 32 \\
\hline $\begin{array}{l}\text { BURSTS } \\
\text { FILTERED } \\
\text { OUT }(\%)\end{array}$ & 7 & & & & \\
\hline
\end{tabular}

${ }^{1}$ Flow sample volume located $9 \mathrm{~cm}$ above top of litter.

${ }^{2}$ MicroCAT temperature and conductance measured $17 \mathrm{~cm}$ above top of litter.

${ }^{3}$ Depth variation determined from stage recorded at P33 gage. 
Table C - 5. Daily mean flow velocities, MicroCAT water temperatures and specific conductances, and water depths at station GS-33 during deployment period 01/22/03 1100-04/15/03 1730.

$\left[\mathrm{cm} / \mathrm{s}\right.$, centimeters per second; ${ }^{\circ} \mathrm{CW}$ from $\mathrm{MN}$, degrees clockwise from magnetic north; ${ }^{\circ} \mathrm{C}$, degrees Celsius; $\mu \mathrm{S} / \mathrm{cm}$ microsiemens per centimeter at 25 degrees Celsius; cm, centimeters; *, all bursts filtered out; --, no data; \%, percent]

\begin{tabular}{|c|c|c|c|c|c|}
\hline Date & $\begin{array}{l}\text { Flow velocity }{ }^{1} \\
\qquad(\mathrm{~cm} / \mathrm{s})\end{array}$ & $\begin{array}{l}\text { Flow direction }{ }^{1} \\
\text { ( }{ }^{\circ} \mathrm{CW} \text { from MN) }\end{array}$ & $\begin{array}{c}\text { Temperature }^{2} \\
\left({ }^{\circ} \mathrm{C}\right)\end{array}$ & $\begin{array}{c}\text { Specific } \\
\text { conductance }^{2} \\
(\mu \mathrm{S} / \mathrm{cm})\end{array}$ & $\begin{array}{l}\text { Water depth }{ }^{3} \\
\text { (cm) }\end{array}$ \\
\hline $01 / 23 / 03$ & 0.61 & 224 & 15.74 & 643 & 26 \\
\hline $01 / 24 / 03$ & 0.65 & 222 & 12.13 & 651 & 26 \\
\hline $01 / 25 / 03$ & 0.69 & 224 & 11.68 & 657 & 25 \\
\hline $01 / 26 / 03$ & 0.73 & 223 & 14.31 & 655 & 25 \\
\hline 01/27/03 & 0.63 & 222 & 15.05 & 653 & 25 \\
\hline $01 / 28 / 03$ & 0.65 & 221 & 14.16 & 654 & 25 \\
\hline $01 / 29 / 03$ & 0.69 & 220 & 15.93 & 650 & 24 \\
\hline $01 / 30 / 03$ & 0.67 & 223 & 17.48 & 646 & 25 \\
\hline $01 / 31 / 03$ & 0.64 & 225 & 19.20 & 642 & 24 \\
\hline 02/01/03 & 0.64 & 228 & 19.44 & 637 & 24 \\
\hline $02 / 02 / 03$ & 0.62 & 227 & 17.90 & 636 & 24 \\
\hline $02 / 03 / 03$ & 0.63 & 226 & 18.22 & 631 & 24 \\
\hline $02 / 04 / 03$ & 0.65 & 225 & 18.92 & 626 & 24 \\
\hline $02 / 05 / 03$ & 0.61 & 224 & 19.72 & 619 & 24 \\
\hline $02 / 06 / 03$ & 0.61 & 222 & 19.96 & 616 & 24 \\
\hline 02/07/03 & 0.65 & 226 & 20.88 & 610 & 24 \\
\hline 02/08/03 & 0.65 & 225 & 21.91 & 605 & 24 \\
\hline $02 / 09 / 03$ & 0.66 & 228 & 21.80 & 603 & 24 \\
\hline $02 / 10 / 03$ & 0.58 & 231 & 22.63 & 599 & 23 \\
\hline $02 / 11 / 03$ & 0.53 & 231 & 22.22 & 594 & 23 \\
\hline $02 / 12 / 03$ & 0.50 & 229 & 20.34 & 588 & 23 \\
\hline $02 / 13 / 03$ & 0.53 & 231 & 18.56 & 586 & 23 \\
\hline $02 / 14 / 03$ & $*$ & $*$ & 18.65 & 583 & 22 \\
\hline $02 / 15 / 03$ & $*$ & $*$ & 20.05 & 579 & 22 \\
\hline $02 / 16 / 03$ & * & * & 22.00 & 575 & 22 \\
\hline $02 / 17 / 03$ & $*$ & $*$ & 22.31 & 571 & 22 \\
\hline $02 / 18 / 03$ & $*$ & $*$ & 20.71 & 570 & 22 \\
\hline $02 / 19 / 03$ & $*$ & $*$ & 21.21 & 570 & 22 \\
\hline $02 / 20 / 03$ & $*$ & $*$ & 22.97 & 534 & 22 \\
\hline $02 / 21 / 03$ & $*$ & $*$ & 23.68 & 467 & 24 \\
\hline $02 / 22 / 03$ & $*$ & * & 24.83 & 480 & 24 \\
\hline $02 / 23 / 03$ & $*$ & $*$ & 23.14 & 472 & 24 \\
\hline $02 / 24 / 03$ & $*$ & $*$ & 21.03 & 462 & 24 \\
\hline $02 / 25 / 03$ & $*$ & $*$ & 22.35 & 459 & 24 \\
\hline
\end{tabular}


Table C - 5. Daily mean flow velocities, MicroCAT water temperatures and specific conductances, and water depths at station GS-33 during deployment period 01/22/03 1100-04/15/03 1730—Continued

\begin{tabular}{|c|c|c|c|c|c|}
\hline Date & $\begin{array}{l}\text { Flow velocity }{ }^{1} \\
\qquad(\mathrm{~cm} / \mathrm{s})\end{array}$ & $\begin{array}{l}\text { Flow direction }{ }^{1} \\
\left({ }^{\circ} \mathrm{CW} \text { from MN) }\right.\end{array}$ & $\begin{array}{c}\text { Temperature }{ }^{2} \\
\left({ }^{\circ} \mathrm{C}\right)\end{array}$ & $\begin{array}{c}\text { Specific } \\
\text { conductance }^{2} \\
(\mu \mathrm{S} / \mathrm{cm})\end{array}$ & $\begin{array}{l}\text { Water depth } \\
\text { (cm) }\end{array}$ \\
\hline $02 / 26 / 03$ & $*$ & $*$ & 23.60 & 450 & 24 \\
\hline $02 / 27 / 03$ & $*$ & $*$ & 24.23 & 453 & 24 \\
\hline $02 / 28 / 03$ & $*$ & $*$ & 25.15 & 457 & 24 \\
\hline 03/01/03 & $*$ & $*$ & 25.57 & 458 & 24 \\
\hline 03/02/03 & $*$ & $*$ & 25.71 & 463 & 23 \\
\hline 03/03/03 & $*$ & $*$ & 25.69 & 469 & 23 \\
\hline 03/04/03 & $*$ & $*$ & 26.23 & 470 & 22 \\
\hline 03/05/03 & $*$ & $*$ & 26.42 & 473 & 22 \\
\hline 03/06/03 & $*$ & $*$ & 26.06 & 475 & 22 \\
\hline 03/07/03 & $*$ & * & 26.45 & 479 & 22 \\
\hline 03/08/03 & $*$ & $*$ & 26.72 & 477 & 21 \\
\hline 03/09/03 & $*$ & $*$ & 26.96 & 478 & 21 \\
\hline 03/10/03 & $*$ & * & 25.93 & 478 & 20 \\
\hline 03/11/03 & $*$ & $*$ & 26.45 & 480 & 20 \\
\hline 03/12/03 & $*$ & * & 26.13 & 480 & 20 \\
\hline 03/13/03 & $*$ & * & 26.13 & 483 & 20 \\
\hline $03 / 14 / 03$ & $*$ & $*$ & 26.54 & 482 & 20 \\
\hline 03/15/03 & $*$ & * & 26.91 & 482 & 19 \\
\hline 03/16/03 & $*$ & $*$ & 25.52 & 486 & 19 \\
\hline 03/17/03 & $*$ & * & 24.89 & 439 & 20 \\
\hline 03/18/03 & $*$ & * & 25.33 & 420 & 21 \\
\hline 03/19/03 & $*$ & $*$ & 27.24 & 437 & 21 \\
\hline 03/20/03 & $*$ & * & 27.68 & 450 & 21 \\
\hline $03 / 21 / 03$ & $*$ & $*$ & 27.95 & 443 & 20 \\
\hline $03 / 22 / 03$ & $*$ & $*$ & 28.40 & 443 & 20 \\
\hline 03/23/03 & $*$ & * & 27.15 & 452 & 20 \\
\hline $03 / 24 / 03$ & $*$ & $*$ & 25.46 & 459 & 20 \\
\hline $03 / 25 / 03$ & $*$ & $*$ & 23.70 & 461 & 20 \\
\hline 03/26/03 & $*$ & $*$ & 24.18 & 464 & 20 \\
\hline 03/27/03 & $*$ & $*$ & 23.59 & 454 & 20 \\
\hline 03/28/03 & $*$ & $*$ & 24.95 & 436 & 21 \\
\hline 03/29/03 & $*$ & $*$ & 25.88 & 439 & 21 \\
\hline 03/30/03 & $*$ & $*$ & 24.53 & 445 & 21 \\
\hline $03 / 31 / 03$ & $*$ & $*$ & 18.96 & 473 & 21 \\
\hline
\end{tabular}


Table C - 5. Daily mean flow velocities, MicroCAT water temperatures and specific conductances, and water depths at station GS-33 during deployment period 01/22/03 1100-04/15/03 1730_Continued

\begin{tabular}{|c|c|c|c|c|c|}
\hline Date & $\begin{array}{l}\text { Flow velocity }{ }^{1} \\
\qquad(\mathrm{~cm} / \mathrm{s})\end{array}$ & $\begin{array}{l}\text { Flow direction }{ }^{1} \\
\left({ }^{\circ} \mathrm{CW} \text { from MN) }\right.\end{array}$ & $\begin{array}{c}\text { Temperature }^{2} \\
\left({ }^{\circ} \mathrm{C}\right)\end{array}$ & $\begin{array}{c}\text { Specific } \\
\text { conductance }^{2} \\
(\mu \mathrm{S} / \mathrm{cm})\end{array}$ & $\begin{array}{l}\text { Water depth } \\
\text { (cm) }\end{array}$ \\
\hline 04/01/03 & $*$ & $*$ & 17.63 & 485 & 21 \\
\hline $04 / 02 / 03$ & $*$ & * & 20.32 & 485 & 20 \\
\hline $04 / 03 / 03$ & $*$ & $*$ & 22.24 & 478 & 20 \\
\hline $04 / 04 / 03$ & $*$ & $*$ & 23.94 & 476 & - - \\
\hline $04 / 05 / 03$ & $*$ & $*$ & 24.05 & 485 & - \\
\hline $04 / 06 / 03$ & $*$ & $*$ & 25.52 & 481 & - \\
\hline 04/07/03 & $*$ & $*$ & 26.34 & 481 & - \\
\hline 04/08/03 & $*$ & $*$ & 26.39 & 479 & -- \\
\hline $04 / 09 / 03$ & $*$ & $*$ & 25.23 & 488 & - \\
\hline $04 / 10 / 03$ & $*$ & $*$ & 23.00 & 498 & -- \\
\hline $04 / 11 / 03$ & $*$ & $*$ & 21.61 & 502 & - \\
\hline $04 / 12 / 03$ & $*$ & $*$ & 22.40 & 496 & - \\
\hline $04 / 13 / 03$ & $*$ & $*$ & 23.56 & 490 & - \\
\hline $04 / 14 / 03$ & $*$ & $*$ & 23.77 & 488 & -- \\
\hline MINIMUM & 0.50 & 220 & 11.68 & 420 & 19 \\
\hline MAXIMUM & 0.73 & 231 & 28.40 & 657 & 26 \\
\hline AVERAGE & 0.63 & 225 & 22.68 & 520 & 22 \\
\hline $\begin{array}{l}\text { BURSTS } \\
\text { FILTERED } \\
\text { OUT }(\%)\end{array}$ & 72 & & & & \\
\hline
\end{tabular}

${ }^{1}$ Flow sample volume located $9 \mathrm{~cm}$ above top of litter.

${ }^{2}$ MicroCAT temperature and conductance measured $17 \mathrm{~cm}$ above top of litter.

${ }^{3}$ Depth variation determined from stage recorded at P33 gage. 
Appendix D. Daily mean flow velocities, water temperatures, specific conductances, and water depths at station GS-36, Shark River Slough, Everglades National Park, Florida during the 2002-2003 wet season. 
Table D-1. Daily mean flow velocities, MicroCAT water temperatures and specific conductances, and water depths at station GS-36 during deployment period 07/24/02 1400-08/27/02 1400 .

$\left[\mathrm{cm} / \mathrm{s}\right.$, centimeters per second; ${ }^{\circ} \mathrm{CW}$ from $\mathrm{MN}$, degrees clockwise from magnetic north; ${ }^{\circ} \mathrm{C}$, degrees Celsius; $\mu \mathrm{S} / \mathrm{cm}$ microsiemens per centimeter at 25 degrees Celsius; $\mathrm{cm}$, centimeters; --, no data; \%, percent]

\begin{tabular}{|c|c|c|c|c|c|}
\hline Date & $\begin{array}{l}\text { Flow velocity }{ }^{1} \\
\text { (cm/s) }\end{array}$ & $\begin{array}{l}\text { Flow direction }{ }^{1} \\
\left({ }^{\circ} \mathrm{CW} \text { from MN) }\right.\end{array}$ & $\begin{array}{c}\text { Temperature }^{2} \\
\left({ }^{\circ} \mathrm{C}\right)\end{array}$ & $\begin{array}{c}\text { Specific } \\
\text { conductance }^{2} \\
(\mu \mathrm{S} / \mathrm{cm})\end{array}$ & $\begin{array}{l}\text { Water depth } \\
\text { (cm) }\end{array}$ \\
\hline $07 / 25 / 02$ & 2.08 & 213 & 32.03 & 345 & 34 \\
\hline 07/26/02 & 2.03 & 215 & 32.32 & 347 & 34 \\
\hline $07 / 27 / 02$ & 1.94 & 217 & 32.76 & 350 & 33 \\
\hline 07/28/02 & 1.99 & 217 & 32.78 & 353 & 33 \\
\hline 07/29/02 & 1.97 & 218 & 31.95 & 357 & 33 \\
\hline 07/30/02 & 1.92 & 218 & 31.78 & 359 & 32 \\
\hline 07/31/02 & 1.91 & 218 & 32.11 & 366 & 32 \\
\hline 08/01/02 & 1.91 & 219 & 32.69 & 370 & 32 \\
\hline 08/02/02 & 1.82 & 220 & 33.13 & 372 & 32 \\
\hline 08/03/02 & 1.74 & 221 & 33.25 & 372 & 31 \\
\hline 08/04/02 & 1.72 & 219 & 32.50 & 373 & 31 \\
\hline 08/05/02 & 1.73 & 219 & 31.83 & 370 & 32 \\
\hline 08/06/02 & 1.59 & 220 & 31.91 & 368 & 32 \\
\hline 08/07/02 & 1.70 & 221 & 31.18 & 366 & 32 \\
\hline 08/08/02 & 1.56 & 222 & 31.07 & 364 & 33 \\
\hline 08/09/02 & 1.50 & 222 & 30.97 & 356 & 34 \\
\hline 08/10/02 & 1.54 & 222 & 29.39 & 358 & 34 \\
\hline 08/11/02 & 1.51 & 220 & 29.40 & 356 & 34 \\
\hline 08/12/02 & 1.64 & 220 & 29.48 & 361 & 35 \\
\hline 08/13/02 & 1.70 & 222 & 30.48 & 365 & 35 \\
\hline 08/14/02 & 1.61 & 224 & 30.89 & 368 & 35 \\
\hline
\end{tabular}


Table D-1. Daily mean flow velocities, MicroCAT water temperatures and specific conductances, and water depths at station GS-36 during deployment period 07/24/02 1400-08/27/02 1400_Continued

\begin{tabular}{|c|c|c|c|c|c|}
\hline Date & $\begin{array}{l}\text { Flow velocity } \\
\qquad(\mathrm{cm} / \mathrm{s})\end{array}$ & $\begin{array}{l}\text { Flow direction }{ }^{1} \\
\left({ }^{\circ} \mathrm{CW} \text { from } \mathrm{MN}\right)\end{array}$ & $\begin{array}{c}\text { Temperature }^{2} \\
\left({ }^{\circ} \mathrm{C}\right)\end{array}$ & $\begin{array}{c}\text { Specific } \\
\text { conductance }^{2} \\
(\mu \mathrm{S} / \mathrm{cm})\end{array}$ & $\begin{array}{l}\text { Water depth } \\
\text { (cm) }\end{array}$ \\
\hline 08/15/02 & 1.67 & 222 & 31.28 & 366 & 36 \\
\hline 08/16/02 & 1.45 & 226 & 30.56 & 361 & 36 \\
\hline 08/17/02 & 1.49 & 222 & 31.31 & 355 & 37 \\
\hline 08/18/02 & 1.76 & 222 & 31.69 & 354 & 37 \\
\hline 08/19/02 & 1.75 & 222 & 31.59 & 348 & 38 \\
\hline 08/20/02 & 1.72 & 220 & 30.41 & 345 & 39 \\
\hline 08/21/02 & 1.62 & 222 & 29.91 & 352 & 39 \\
\hline 08/22/02 & 1.58 & 223 & 31.30 & 363 & 39 \\
\hline 08/23/02 & 1.70 & 222 & 32.16 & 377 & -- \\
\hline 08/24/02 & 1.80 & 222 & 32.06 & 382 & -- \\
\hline 08/25/02 & 1.67 & 223 & 32.14 & 385 & 38 \\
\hline 08/26/02 & 1.63 & 220 & 31.77 & 384 & 38 \\
\hline MINIMUM & 1.45 & 213 & 29.39 & 345 & 31 \\
\hline MAXIMUM & 2.08 & 226 & 33.25 & 385 & 39 \\
\hline AVERAGE & 1.73 & 220 & 31.52 & 363 & 34 \\
\hline $\begin{array}{l}\text { BURSTS } \\
\text { FILTERED } \\
\text { OUT }(\%)\end{array}$ & 0 & & & & \\
\hline
\end{tabular}

${ }^{1}$ Flow sample volume located $20 \mathrm{~cm}$ above top of litter.

${ }^{2}$ MicroCAT temperature and conductance measured $15 \mathrm{~cm}$ above top of litter.

${ }^{3}$ Depth variation determined from stage recorded at P36 gage. 
Table D - 2. Daily mean flow velocities, MicroCAT water temperatures and specific conductances, and water depths at station GS-36 during deployment period 08/28/02 1200-10/29/02 1530.

$\left[\mathrm{cm} / \mathrm{s}\right.$, centimeters per second; ${ }^{\circ} \mathrm{CW}$ from $\mathrm{MN}$, degrees clockwise from magnetic north; ${ }^{\circ} \mathrm{C}$, degrees Celsius; $\mu \mathrm{S} / \mathrm{cm}$ microsiemens per centimeter at 25 degrees Celsius; cm, centimeters; *, all bursts filtered out; - -, no data; \%, percent]

\begin{tabular}{|c|c|c|c|c|c|}
\hline Date & $\begin{array}{l}\text { Flow velocity } \\
\text { (cm/s) }\end{array}$ & $\begin{array}{l}\text { Flow direction }{ }^{1} \\
\left({ }^{\circ} \mathrm{CW} \text { from MN) }\right.\end{array}$ & $\begin{array}{c}\text { Temperature }{ }^{2} \\
\left({ }^{\circ} \mathrm{C}\right)\end{array}$ & $\begin{array}{c}\text { Specific } \\
\text { conductance }^{2} \\
(\mu \mathrm{S} / \mathrm{cm})\end{array}$ & $\begin{array}{l}\text { Water depth } \\
\qquad \text { (cm) }\end{array}$ \\
\hline 08/29/02 & 1.94 & 217 & 30.06 & 384 & 40 \\
\hline 08/30/02 & 1.90 & 218 & 29.33 & 381 & 40 \\
\hline 08/31/02 & 2.04 & 219 & 29.58 & 385 & -- \\
\hline 09/01/02 & 2.06 & 220 & 29.95 & 390 & -- \\
\hline 09/02/02 & 2.10 & 221 & 30.18 & 397 & 42 \\
\hline 09/03/02 & 2.05 & 219 & 31.26 & 400 & 42 \\
\hline 09/04/02 & 2.00 & 219 & 31.65 & 404 & -- \\
\hline 09/05/02 & 1.96 & 219 & 31.27 & 404 & -- \\
\hline 09/06/02 & 1.78 & 218 & 30.02 & 390 & -- \\
\hline 09/07/02 & 1.85 & 218 & 30.02 & 405 & -- \\
\hline 09/08/02 & 1.87 & 217 & 30.08 & 412 & -- \\
\hline 09/09/02 & 1.88 & 218 & 30.97 & 413 & -- \\
\hline 09/10/02 & 1.88 & 217 & 30.94 & 417 & -- \\
\hline 09/11/02 & 1.91 & 217 & 29.33 & 422 & -- \\
\hline 09/12/02 & 1.84 & 218 & 27.61 & 423 & -- \\
\hline 09/13/02 & 1.56 & 223 & 28.69 & 431 & -- \\
\hline 09/14/02 & 1.64 & 220 & 30.28 & 434 & -- \\
\hline 09/15/02 & 2.10 & 219 & 30.80 & 438 & -- \\
\hline 09/16/02 & 2.15 & 219 & 30.80 & 444 & -- \\
\hline 09/17/02 & 2.13 & 219 & 31.31 & 455 & -- \\
\hline 09/18/02 & 2.23 & 219 & 31.46 & 461 & -- \\
\hline 09/19/02 & 2.36 & 220 & 31.12 & 467 & -- \\
\hline 09/20/02 & 2.31 & 220 & 30.64 & 472 & -- \\
\hline 09/21/02 & 2.29 & 219 & 30.23 & 472 & -- \\
\hline 09/22/02 & 2.31 & 220 & 29.88 & 481 & -- \\
\hline 09/23/02 & 2.43 & 221 & 28.97 & 485 & -- \\
\hline 09/24/02 & 2.21 & 225 & 28.90 & 485 & -- \\
\hline 09/25/02 & 2.12 & 228 & 29.81 & 491 & 43 \\
\hline 09/26/02 & 2.11 & 228 & 30.21 & 493 & 42 \\
\hline 09/27/02 & 2.01 & 227 & 30.52 & 488 & 42 \\
\hline 09/28/02 & 2.03 & 226 & 30.72 & 485 & 43 \\
\hline 09/29/02 & 2.12 & 226 & 30.71 & 476 & 44 \\
\hline 09/30/02 & 2.05 & 227 & 30.13 & 469 & 44 \\
\hline $10 / 01 / 02$ & 1.80 & 227 & 30.02 & 460 & 44 \\
\hline
\end{tabular}


Table D - 2. Daily mean flow velocities, MicroCAT water temperatures and specific conductances, and water depths at station GS-36 during deployment period 08/28/02 1200-10/29/02 1530-Continued

\begin{tabular}{|c|c|c|c|c|c|}
\hline Date & $\begin{array}{l}\text { Flow velocity }{ }^{1} \\
\quad(\mathrm{~cm} / \mathrm{s})\end{array}$ & $\begin{array}{l}\text { Flow direction }{ }^{1} \\
\left({ }^{\circ} \mathrm{CW} \text { from } \mathrm{MN}\right)\end{array}$ & $\begin{array}{l}\text { Temperature } \\
\left({ }^{\circ} \mathrm{C}\right)\end{array}$ & $\begin{array}{c}\text { Specific } \\
\text { conductance } \\
(\mu \mathrm{S} / \mathrm{cm})\end{array}$ & $\begin{array}{l}\text { Water depth } \\
\quad \text { (cm) }\end{array}$ \\
\hline $10 / 02 / 02$ & 1.64 & 228 & 30.35 & 456 & 44 \\
\hline $10 / 03 / 02$ & 1.53 & 229 & 30.49 & 451 & 43 \\
\hline $10 / 04 / 02$ & 1.47 & 229 & 30.09 & 451 & 43 \\
\hline $10 / 05 / 02$ & 1.43 & 228 & 29.93 & 451 & 42 \\
\hline $10 / 06 / 02$ & 1.58 & 227 & 29.40 & 451 & 42 \\
\hline $10 / 07 / 02$ & 1.63 & 228 & 29.54 & 453 & 42 \\
\hline $10 / 08 / 02$ & 1.59 & 227 & 29.51 & 456 & 41 \\
\hline $10 / 09 / 02$ & 1.44 & 223 & 29.04 & 458 & 41 \\
\hline 10/10/02 & 1.71 & 226 & 29.43 & 454 & 41 \\
\hline 10/11/02 & 1.68 & 225 & 29.32 & 449 & 42 \\
\hline $10 / 12 / 02$ & 1.66 & 225 & 29.46 & 457 & 42 \\
\hline $10 / 13 / 02$ & 2.12 & 225 & 29.98 & 454 & 42 \\
\hline $10 / 14 / 02$ & 2.17 & 224 & 29.44 & 456 & 41 \\
\hline $10 / 15 / 02$ & 2.08 & 223 & 29.00 & 450 & 41 \\
\hline $10 / 16 / 02$ & 1.82 & 222 & 28.28 & 435 & 42 \\
\hline $10 / 17 / 02$ & 1.74 & 222 & 27.37 & 436 & 42 \\
\hline $10 / 18 / 02$ & 1.99 & 222 & 26.49 & 438 & 41 \\
\hline $10 / 19 / 02$ & 2.22 & 222 & 26.60 & 438 & 41 \\
\hline $10 / 20 / 02$ & 2.24 & 222 & 27.19 & 433 & 41 \\
\hline $10 / 21 / 02$ & 2.21 & 221 & 26.81 & 422 & 41 \\
\hline $10 / 22 / 02$ & $*$ & $*$ & 27.26 & 420 & 42 \\
\hline $10 / 23 / 02$ & $*$ & $*$ & 28.47 & 419 & 42 \\
\hline $10 / 24 / 02$ & * & $*$ & 28.75 & 423 & 42 \\
\hline $10 / 25 / 02$ & $*$ & $*$ & 28.94 & 423 & 41 \\
\hline $10 / 26 / 02$ & * & $*$ & 28.93 & 422 & 41 \\
\hline $10 / 27 / 02$ & $*$ & $*$ & 29.24 & 424 & 41 \\
\hline $10 / 28 / 02$ & $*$ & $*$ & 29.36 & 427 & 40 \\
\hline MINIMUM & 1.43 & 217 & 26.49 & 381 & 40 \\
\hline MAXIMUM & 2.43 & 229 & 31.65 & 493 & 44 \\
\hline AVERAGE & 1.94 & 222 & 29.61 & 440 & 42 \\
\hline $\begin{array}{l}\text { BURSTS } \\
\text { FILTERED } \\
\text { OUT }(\%)\end{array}$ & 12 & & & & \\
\hline
\end{tabular}

${ }^{1}$ Flow sample volume located $20 \mathrm{~cm}$ above top of litter.

${ }^{2}$ MicroCAT temperature and conductance measured $15 \mathrm{~cm}$ above top of litter.

${ }^{3}$ Depth variation determined from stage recorded at P36 gage. 
Table D - 3. Daily mean flow velocities, MicroCAT water temperatures and specific conductances, and water depths at station GS-36 during deployment period 10/30/02 1000-12/03/02 1230.

$\left[\mathrm{cm} / \mathrm{s}\right.$, centimeters per second; ${ }^{\circ} \mathrm{CW}$ from $\mathrm{MN}$, degrees clockwise from magnetic north; ${ }^{\circ} \mathrm{C}$, degrees Celsius; $\mu \mathrm{S} / \mathrm{cm}$ microsiemens per centimeter at 25 degrees Celsius; cm, centimeters; \%, percent]

\begin{tabular}{|c|c|c|c|c|c|}
\hline Date & $\begin{array}{l}\text { Flow velocity }{ }^{1} \\
\qquad(\mathrm{~cm} / \mathrm{s})\end{array}$ & $\begin{array}{l}\text { Flow direction }{ }^{1} \\
\left({ }^{\circ} \mathrm{CW} \text { from MN) }\right.\end{array}$ & $\begin{array}{c}\text { Temperature }{ }^{2} \\
\left({ }^{\circ} \mathrm{C}\right)\end{array}$ & $\begin{array}{c}\text { Specific } \\
\text { conductance }^{2} \\
\text { ( } \mathrm{S} / \mathrm{cm})\end{array}$ & $\begin{array}{l}\text { Water depth } \\
\text { (cm) }\end{array}$ \\
\hline $10 / 31 / 02$ & 1.90 & 223 & 29.22 & 435 & 39 \\
\hline $11 / 01 / 02$ & 1.99 & 223 & 28.91 & 436 & 39 \\
\hline $11 / 02 / 02$ & 1.94 & 223 & 27.86 & 437 & 38 \\
\hline $11 / 03 / 02$ & 1.98 & 224 & 26.90 & 438 & 38 \\
\hline $11 / 04 / 02$ & 1.96 & 224 & 26.67 & 441 & 38 \\
\hline $11 / 05 / 02$ & 2.02 & 224 & 27.03 & 443 & 37 \\
\hline $11 / 06 / 02$ & 1.94 & 222 & 27.40 & 447 & 37 \\
\hline $11 / 07 / 02$ & 1.79 & 224 & 24.85 & 451 & 36 \\
\hline $11 / 08 / 02$ & 1.85 & 224 & 23.36 & 454 & 36 \\
\hline $11 / 09 / 02$ & 1.83 & 223 & 24.04 & 456 & 36 \\
\hline $11 / 10 / 02$ & 1.92 & 224 & 24.66 & 460 & 35 \\
\hline $11 / 11 / 02$ & 1.84 & 223 & 25.30 & 464 & 35 \\
\hline $11 / 12 / 02$ & 1.91 & 224 & 26.58 & 467 & 35 \\
\hline $11 / 13 / 02$ & 1.75 & 224 & 25.24 & 466 & 35 \\
\hline $11 / 14 / 02$ & 1.55 & 225 & 22.14 & 468 & 35 \\
\hline $11 / 15 / 02$ & 1.46 & 225 & 23.05 & 470 & 34 \\
\hline $11 / 16 / 02$ & 1.46 & 227 & 23.58 & 458 & 35 \\
\hline $11 / 17 / 02$ & 1.41 & 226 & 22.44 & 401 & 41 \\
\hline $11 / 18 / 02$ & 1.47 & 223 & 19.28 & 410 & 41 \\
\hline 11/19/02 & 1.49 & 220 & 19.59 & 420 & 41 \\
\hline
\end{tabular}


Table D - 3. Daily mean flow velocities, MicroCAT water temperatures and specific conductances, and water depths at station GS-36 during deployment period 10/30/02 1000-12/03/02 1230_Continued

\begin{tabular}{|c|c|c|c|c|c|}
\hline Date & $\begin{array}{l}\text { Flow velocity }{ }^{1} \\
\qquad(\mathrm{~cm} / \mathrm{s})\end{array}$ & $\begin{array}{l}\text { Flow direction' } \\
\text { ( }{ }^{\circ} \mathrm{CW} \text { from MN) }\end{array}$ & $\begin{array}{c}\text { Temperature }{ }^{2} \\
\left({ }^{\circ} \mathrm{C}\right)\end{array}$ & $\begin{array}{c}\text { Specific } \\
\text { conductance }^{2} \\
\text { ( } \mathrm{S} / \mathrm{cm})\end{array}$ & $\begin{array}{l}\text { Water depth } \\
\text { (cm) }\end{array}$ \\
\hline $11 / 20 / 02$ & 1.49 & 220 & 21.56 & 422 & 41 \\
\hline $11 / 21 / 02$ & 1.44 & 223 & 23.35 & 430 & 40 \\
\hline $11 / 22 / 02$ & 1.43 & 223 & 23.71 & 434 & 40 \\
\hline $11 / 23 / 02$ & 1.59 & 223 & 21.49 & 452 & 40 \\
\hline $11 / 24 / 02$ & 1.47 & 224 & 20.30 & 461 & 39 \\
\hline $11 / 25 / 02$ & 1.33 & 227 & 21.78 & 472 & 39 \\
\hline $11 / 26 / 02$ & 1.46 & 225 & 22.85 & 481 & 38 \\
\hline $11 / 27 / 02$ & 1.39 & 227 & 22.36 & 485 & 38 \\
\hline $11 / 28 / 02$ & 1.28 & 229 & 21.68 & 492 & 37 \\
\hline $11 / 29 / 02$ & 1.29 & 228 & 19.95 & 504 & 37 \\
\hline $11 / 30 / 02$ & 1.26 & 230 & 18.81 & 512 & 36 \\
\hline $12 / 01 / 02$ & 1.20 & 236 & 19.45 & 518 & 35 \\
\hline $12 / 02 / 02$ & 1.13 & 236 & 20.74 & 529 & 35 \\
\hline MINIMUM & 1.13 & 220 & 18.81 & 401 & 34 \\
\hline MAXIMUM & 2.02 & 236 & 29.22 & 529 & 41 \\
\hline AVERAGE & 1.61 & 225 & 23.52 & 458 & 37 \\
\hline $\begin{array}{l}\text { BURSTS } \\
\text { FILTERED } \\
\text { OUT }(\%)\end{array}$ & 0 & & & & \\
\hline
\end{tabular}

${ }^{1}$ Flow sample volume located $20 \mathrm{~cm}$ above top of litter.

${ }^{2}$ MicroCAT temperature and conductance measured $15 \mathrm{~cm}$ above top of litter.

${ }^{3}$ Depth variation determined from stage recorded at P36 gage. 
Table D - 4. Daily mean flow velocities, MicroCAT water temperatures and specific conductances, and water depths at station GS-36 during deployment period 12/04/02 1000-01/21/03 1230.

$\left[\mathrm{cm} / \mathrm{s}\right.$, centimeters per second; ${ }^{\circ} \mathrm{CW}$ from $\mathrm{MN}$, degrees clockwise from magnetic north; ${ }^{\circ} \mathrm{C}$, degrees Celsius; $\mu \mathrm{S} / \mathrm{cm}$ microsiemens per centimeter at 25 degrees Celsius; cm, centimeters; \%, percent]

\begin{tabular}{|c|c|c|c|c|c|}
\hline Date & $\begin{array}{l}\text { Flow velocity }{ }^{1} \\
(\mathrm{~cm} / \mathrm{s})\end{array}$ & $\begin{array}{l}\text { Flow direction }{ }^{1} \\
\text { ( } \mathrm{CW} \text { from } \mathrm{MN} \text { ) }\end{array}$ & $\begin{array}{c}\text { Temperature }^{2} \\
\left({ }^{\circ} \mathrm{C}\right)\end{array}$ & $\begin{array}{c}\text { Specific } \\
\text { conductance }^{2} \\
(\mu \mathrm{S} / \mathrm{cm})\end{array}$ & $\begin{array}{l}\text { Water depth } \\
\text { (cm) }\end{array}$ \\
\hline $12 / 05 / 02$ & 1.00 & 220 & 23.63 & 541 & 34 \\
\hline $12 / 06 / 02$ & 0.94 & 224 & 24.44 & 544 & 33 \\
\hline $12 / 07 / 02$ & 1.02 & 228 & 22.23 & 547 & 33 \\
\hline $12 / 08 / 02$ & 1.04 & 222 & 22.28 & 549 & 32 \\
\hline $12 / 09 / 02$ & 1.03 & 225 & 22.37 & 537 & 33 \\
\hline $12 / 10 / 02$ & 1.06 & 226 & 23.05 & 483 & 37 \\
\hline $12 / 11 / 02$ & 1.05 & 225 & 23.98 & 490 & 37 \\
\hline $12 / 12 / 02$ & 1.00 & 226 & 24.65 & 497 & 37 \\
\hline $12 / 13 / 02$ & 1.07 & 226 & 24.69 & 499 & 37 \\
\hline $12 / 14 / 02$ & 1.05 & 224 & 23.02 & 501 & 37 \\
\hline $12 / 15 / 02$ & 0.98 & 228 & 19.97 & 501 & 36 \\
\hline $12 / 16 / 02$ & 0.97 & 224 & 17.91 & 487 & 35 \\
\hline $12 / 17 / 02$ & 0.94 & 224 & 17.22 & 477 & 35 \\
\hline $12 / 18 / 02$ & 0.90 & 227 & 18.54 & 481 & 34 \\
\hline $12 / 19 / 02$ & 0.97 & 228 & 19.70 & 495 & 34 \\
\hline $12 / 20 / 02$ & 1.02 & 228 & 21.00 & 503 & 33 \\
\hline $12 / 21 / 02$ & 1.03 & 230 & 18.59 & 505 & 33 \\
\hline $12 / 22 / 02$ & 0.98 & 231 & 18.49 & 509 & 32 \\
\hline $12 / 23 / 02$ & 0.91 & 229 & 19.40 & 514 & 32 \\
\hline $12 / 24 / 02$ & 0.91 & 231 & 21.54 & 521 & 31 \\
\hline $12 / 25 / 02$ & 0.91 & 232 & 22.81 & 526 & 31 \\
\hline $12 / 26 / 02$ & 1.09 & 236 & 19.09 & 528 & 31 \\
\hline $12 / 27 / 02$ & 1.00 & 237 & 18.16 & 531 & 30 \\
\hline $12 / 28 / 02$ & 1.00 & 233 & 17.84 & 533 & 29 \\
\hline $12 / 29 / 02$ & 1.09 & 239 & 16.34 & 536 & 29 \\
\hline $12 / 30 / 02$ & 1.13 & 236 & 17.16 & 538 & 29 \\
\hline $12 / 31 / 02$ & 1.12 & 235 & 19.05 & 540 & 28 \\
\hline
\end{tabular}


Table D - 4. Daily mean flow velocities, MicroCAT water temperatures and specific conductances, and water depths at station GS-36 during deployment period 12/04/02 1000-01/21/03 1230_Continued

\begin{tabular}{|c|c|c|c|c|c|}
\hline Date & $\begin{array}{l}\text { Flow velocity }{ }^{1} \\
\quad(\mathrm{~cm} / \mathrm{s})\end{array}$ & $\begin{array}{l}\text { Flow direction }{ }^{1} \\
\left({ }^{\circ} \mathrm{CW} \text { from } \mathrm{MN}\right)\end{array}$ & $\begin{array}{c}\text { Temperature }^{2} \\
\left({ }^{\circ} \mathrm{C}\right)\end{array}$ & $\begin{array}{c}\text { Specific } \\
\text { conductance }^{2} \\
(\mu \mathrm{S} / \mathrm{cm})\end{array}$ & $\begin{array}{l}\text { Water depth } \\
\text { (cm) }\end{array}$ \\
\hline $01 / 01 / 03$ & 1.28 & 237 & 21.76 & 541 & 28 \\
\hline $01 / 02 / 03$ & 1.22 & 235 & 22.57 & 543 & 28 \\
\hline 01/03/03 & 1.17 & 238 & 21.84 & 520 & 29 \\
\hline $01 / 04 / 03$ & 1.15 & 238 & 18.00 & 522 & 29 \\
\hline $01 / 05 / 03$ & 1.19 & 238 & 16.93 & 527 & 28 \\
\hline $01 / 06 / 03$ & 1.22 & 239 & 17.58 & 528 & 28 \\
\hline 01/07/03 & 1.28 & 240 & 16.55 & 533 & 27 \\
\hline 01/08/03 & 1.31 & 238 & 16.01 & 536 & 27 \\
\hline $01 / 09 / 03$ & 1.29 & 236 & 15.98 & 540 & 26 \\
\hline 01/10/03 & 1.29 & 236 & 17.17 & 542 & 26 \\
\hline $01 / 11 / 03$ & 1.32 & 236 & 18.82 & 544 & 25 \\
\hline $01 / 12 / 03$ & 1.35 & 238 & 19.61 & 544 & 25 \\
\hline 01/13/03 & 1.35 & 235 & 19.46 & 547 & 25 \\
\hline $01 / 14 / 03$ & 1.31 & 238 & 19.76 & 547 & 24 \\
\hline $01 / 15 / 03$ & 1.26 & 236 & 17.35 & 551 & 24 \\
\hline 01/16/03 & 1.24 & 234 & 17.19 & 554 & 24 \\
\hline $01 / 17 / 03$ & 1.26 & 237 & 17.99 & 554 & 23 \\
\hline $01 / 18 / 03$ & 1.11 & 239 & 13.85 & 559 & 23 \\
\hline $01 / 19 / 03$ & 1.07 & 230 & 12.59 & 564 & 23 \\
\hline $01 / 20 / 03$ & 1.24 & 233 & 13.55 & 568 & 22 \\
\hline MINIMUM & 0.90 & 220 & 12.59 & 477 & 22 \\
\hline MAXIMUM & 1.35 & 240 & 24.69 & 568 & 37 \\
\hline AVERAGE & 1.11 & 232 & 19.40 & 527 & 30 \\
\hline $\begin{array}{l}\text { BURSTS } \\
\text { FILTERED } \\
\text { OUT }(\%)\end{array}$ & 0 & & & & \\
\hline
\end{tabular}

${ }^{1}$ Flow sample volume located $10 \mathrm{~cm}$ above top of litter.

${ }^{2}$ MicroCAT temperature and conductance measured $15 \mathrm{~cm}$ above top of litter.

${ }^{3}$ Depth variation determined from stage recorded at P36 gage. 
Table D - 5. Daily mean flow velocities, MicroCAT water temperatures and specific conductances, and water depths at station GS-36 during deployment period 01/22/03 1000-04/07/03 0000.

$\left[\mathrm{cm} / \mathrm{s}\right.$, centimeters per second; ${ }^{\circ} \mathrm{CW}$ from $\mathrm{MN}$, degrees clockwise from magnetic north; ${ }^{\circ} \mathrm{C}$, degrees Celsius; $\mu \mathrm{S} / \mathrm{cm}$ microsiemens per centimeter at 25 degrees Celsius; cm, centimeters; ${ }^{*}$, all bursts filtered out; - -, no data; \%, percent]

\begin{tabular}{|c|c|c|c|c|c|}
\hline Date & $\begin{array}{l}\text { Flow velocity }{ }^{1} \\
\qquad(\mathrm{~cm} / \mathrm{s})\end{array}$ & $\begin{array}{l}\text { Flow direction }{ }^{1} \\
\left({ }^{\circ} \mathrm{CW} \text { from MN) }\right.\end{array}$ & $\begin{array}{c}\text { Temperature } \\
\left({ }^{\circ} \mathrm{C}\right)\end{array}$ & $\begin{array}{c}\text { Specific } \\
\text { conductance }^{2} \\
(\mu \mathrm{S} / \mathrm{cm})\end{array}$ & $\begin{array}{l}\text { Water depth } \\
\text { (cm) }\end{array}$ \\
\hline $01 / 23 / 03$ & 1.58 & 241 & 16.96 & 572 & 21 \\
\hline $01 / 24 / 03$ & 1.36 & 237 & 13.03 & 579 & 21 \\
\hline $01 / 25 / 03$ & 1.12 & 236 & 12.57 & 584 & 21 \\
\hline $01 / 26 / 03$ & 1.26 & 235 & 15.32 & 586 & 21 \\
\hline $01 / 27 / 03$ & 1.25 & 236 & 15.60 & 588 & 20 \\
\hline $01 / 28 / 03$ & 1.37 & 230 & 14.99 & 591 & 20 \\
\hline $01 / 29 / 03$ & 1.02 & 226 & 17.21 & 593 & 20 \\
\hline 01/30/03 & 1.09 & 225 & 18.81 & 594 & 20 \\
\hline $01 / 31 / 03$ & 1.14 & 221 & 20.18 & 596 & 19 \\
\hline 02/01/03 & 1.30 & 223 & 19.96 & 594 & 19 \\
\hline $02 / 02 / 03$ & 1.31 & 222 & 18.52 & 596 & 19 \\
\hline $02 / 03 / 03$ & 1.29 & 222 & 19.06 & 599 & 18 \\
\hline $02 / 04 / 03$ & 1.39 & 220 & 19.96 & 601 & 18 \\
\hline $02 / 05 / 03$ & 1.31 & 218 & 20.67 & 602 & 18 \\
\hline 02/06/03 & 1.03 & 218 & 21.24 & 508 & 18 \\
\hline 02/07/03 & 0.81 & 225 & 22.53 & -- & 18 \\
\hline 02/08/03 & $*$ & $*$ & 22.64 & -- & 17 \\
\hline 02/09/03 & $*$ & $*$ & 22.59 & -- & 17 \\
\hline $02 / 10 / 03$ & 0.81 & 218 & 23.52 & -- & 17 \\
\hline 02/11/03 & 1.22 & 220 & 22.48 & -- & 17 \\
\hline $02 / 12 / 03$ & 1.33 & 224 & 19.68 & -- & 16 \\
\hline $02 / 13 / 03$ & 1.32 & 228 & 18.07 & -- & 16 \\
\hline 02/14/03 & 1.28 & 231 & 18.81 & -- & 16 \\
\hline $02 / 15 / 03$ & 1.34 & 229 & 21.81 & -- & 15 \\
\hline 02/16/03 & 1.43 & 228 & 23.69 & -- & 15 \\
\hline 02/17/03 & 1.09 & 230 & 21.95 & -- & 15 \\
\hline $02 / 18 / 03$ & 0.91 & 229 & 19.45 & -- & 15 \\
\hline $02 / 19 / 03$ & 0.70 & 232 & 22.06 & -- & 15 \\
\hline 02/20/03 & 0.98 & 229 & 23.73 & -- & 15 \\
\hline $02 / 21 / 03$ & 0.86 & 227 & 24.64 & -- & 15 \\
\hline $02 / 22 / 03$ & $*$ & $*$ & 25.30 & -- & 15 \\
\hline $02 / 23 / 03$ & 1.17 & 225 & 21.59 & -- & 15 \\
\hline $02 / 24 / 03$ & 1.37 & 227 & 20.91 & -- & 16 \\
\hline $02 / 25 / 03$ & 1.57 & 226 & 22.76 & -- & 15 \\
\hline
\end{tabular}


Table D - 5. Daily mean flow velocities, MicroCAT water temperatures and specific conductances, and water depths at station GS-36 during deployment period 01/22/03 1000-04/07/03 0000_Continued

\begin{tabular}{|c|c|c|c|c|c|}
\hline Date & $\begin{array}{l}\text { Flow velocity } \\
\qquad(\mathrm{cm} / \mathrm{s})\end{array}$ & $\begin{array}{l}\text { Flow direction }{ }^{1} \\
\left({ }^{\circ} \mathrm{CW} \text { from } \mathrm{MN}\right)\end{array}$ & $\begin{array}{c}\text { Temperature }^{2} \\
\left({ }^{\circ} \mathrm{C}\right)\end{array}$ & $\begin{array}{c}\text { Specific } \\
\text { conductance }^{2} \\
(\mu \mathrm{S} / \mathrm{cm})\end{array}$ & $\begin{array}{l}\text { Water depth } \\
\text { (cm) }\end{array}$ \\
\hline 02/26/03 & 1.63 & 225 & 23.78 & -- & 15 \\
\hline $02 / 27 / 03$ & 1.62 & 224 & 24.97 & -- & 15 \\
\hline $02 / 28 / 03$ & 1.60 & 222 & 26.02 & - - & 15 \\
\hline 03/01/03 & 1.46 & 222 & 25.95 & -- & 15 \\
\hline 03/02/03 & $*$ & $*$ & 25.27 & -- & 15 \\
\hline 03/03/03 & $*$ & $*$ & 25.71 & -- & 14 \\
\hline 03/04/03 & $*$ & $*$ & 26.21 & -- & 14 \\
\hline 03/05/03 & $*$ & $*$ & 26.12 & - & 14 \\
\hline 03/06/03 & $*$ & $*$ & 26.41 & - - & 14 \\
\hline 03/07/03 & $*$ & $*$ & 26.28 & -- & 14 \\
\hline 03/08/03 & $*$ & $*$ & 25.91 & - - & 14 \\
\hline 03/09/03 & $*$ & $*$ & 25.76 & - & 14 \\
\hline 03/10/03 & $*$ & $*$ & 27.22 & -- & 14 \\
\hline 03/11/03 & $*$ & $*$ & 26.08 & -- & 14 \\
\hline 03/12/03 & $*$ & $*$ & 25.69 & - - & 13 \\
\hline 03/13/03 & $*$ & $*$ & 26.41 & -- & 13 \\
\hline 03/14/03 & * & $*$ & 26.99 & -- & 13 \\
\hline 03/15/03 & $*$ & $*$ & 26.84 & - & 13 \\
\hline 03/16/03 & $*$ & $*$ & 25.84 & -- & 13 \\
\hline 03/17/03 & * & $*$ & 24.14 & -- & 15 \\
\hline 03/18/03 & $*$ & $*$ & 26.21 & - & 15 \\
\hline 03/19/03 & $*$ & $*$ & 27.59 & -- & 15 \\
\hline 03/20/03 & $*$ & $*$ & 27.86 & -- & 15 \\
\hline $03 / 21 / 03$ & $*$ & $*$ & 27.71 & -- & 15 \\
\hline 03/22/03 & $*$ & $*$ & 28.45 & -- & 15 \\
\hline 03/23/03 & $*$ & $*$ & 25.34 & -- & 14 \\
\hline $03 / 24 / 03$ & $*$ & $*$ & 21.29 & -- & 14 \\
\hline 03/25/03 & $*$ & $*$ & 20.03 & -- & 14 \\
\hline 03/26/03 & $*$ & $*$ & -- & -- & 14 \\
\hline $03 / 27 / 03$ & $*$ & $*$ & -- & -- & 14 \\
\hline 03/28/03 & $*$ & $*$ & -- & -- & 17 \\
\hline 03/29/03 & $*$ & $*$ & -- & -- & 16 \\
\hline 03/30/03 & $*$ & $*$ & -- & -- & 16 \\
\hline 03/31/03 & $*$ & $*$ & -- & -- & 16 \\
\hline
\end{tabular}


Table D - 5. Daily mean flow velocities, MicroCAT water temperatures and specific conductances, and water depths at station GS-36 during deployment period 01/22/03 1000-04/07/03 0000—Continued

\begin{tabular}{|c|c|c|c|c|c|}
\hline Date & $\begin{array}{l}\text { Flow velocity' } \\
\quad(\mathrm{cm} / \mathrm{s})\end{array}$ & $\begin{array}{l}\text { Flow direction }{ }^{1} \\
\left({ }^{\circ} \mathrm{CW} \text { from } \mathrm{MN}\right)\end{array}$ & $\begin{array}{l}\text { Temperature }{ }^{2} \\
\quad\left({ }^{\circ} \mathrm{C}\right)\end{array}$ & $\begin{array}{c}\text { Specific } \\
\text { conductance }^{2} \\
(\mu \mathrm{S} / \mathrm{cm})\end{array}$ & $\begin{array}{l}\text { Water depth } \\
\quad \text { (cm) }\end{array}$ \\
\hline $04 / 01 / 03$ & * & $*$ & -- & - - & 15 \\
\hline $04 / 02 / 03$ & $*$ & $*$ & -- & -- & 15 \\
\hline $04 / 03 / 03$ & $*$ & $*$ & - - & - & 16 \\
\hline $04 / 04 / 03$ & $*$ & $*$ & -- & -- & -- \\
\hline $04 / 05 / 03$ & $*$ & $*$ & -- & -- & -- \\
\hline $04 / 06 / 03$ & $*$ & $*$ & - - & -- & -- \\
\hline MINIMUM & 0.70 & 218 & 12.57 & 508 & 15 \\
\hline MAXIMUM & 1.63 & 241 & 28.45 & 602 & 21 \\
\hline AVERAGE & 1.24 & 227 & 22.65 & 585 & 16 \\
\hline $\begin{array}{l}\text { BURSTS } \\
\text { FILTERED } \\
\text { OUT }(\%)\end{array}$ & 55 & & & & \\
\hline
\end{tabular}

${ }^{1}$ Flow sample volume located $10 \mathrm{~cm}$ above top of litter.

${ }^{2}$ MicroCAT temperature and conductance measured $15 \mathrm{~cm}$ above top of litter.

${ }^{3}$ Depth variation determined from stage recorded at P36 gage. 
Table D - 6. Daily mean flow velocities, MicroCAT water temperatures and specific conductances, and water depths at station GS-36 during deployment period 06/18/03 1300-07/30/03 1100.

$\left[\mathrm{cm} / \mathrm{s}\right.$, centimeters per second; ${ }^{\circ} \mathrm{CW}$ from $\mathrm{MN}$, degrees clockwise from magnetic north; ${ }^{\circ} \mathrm{C}$, degrees Celsius; $\mu \mathrm{S} / \mathrm{cm}$ microsiemens per centimeter at 25 degrees Celsius; cm, centimeters; --, no data; \%, percent]

\begin{tabular}{|c|c|c|c|c|c|}
\hline Date & $\begin{array}{l}\text { Flow velocity }{ }^{1} \\
\text { (cm/s) }\end{array}$ & $\begin{array}{l}\text { Flow direction }{ }^{1} \\
\text { ( }^{\circ} \mathrm{CW} \text { from MN) }\end{array}$ & $\begin{array}{c}\text { Temperature }{ }^{2} \\
\left({ }^{\circ} \mathrm{C}\right)\end{array}$ & $\begin{array}{c}\text { Specific } \\
\text { conductance }^{2} \\
(\mu \mathrm{S} / \mathrm{cm})\end{array}$ & $\begin{array}{l}\text { Water depth } \\
\text { (cm) }\end{array}$ \\
\hline 06/19/03 & 0.97 & 254 & -- & -- & -- \\
\hline $06 / 20 / 03$ & 0.98 & 258 & - - & -- & - - \\
\hline $06 / 21 / 03$ & 0.98 & 256 & - - & -- & - - \\
\hline $06 / 22 / 03$ & 0.84 & 247 & - & -- & - - \\
\hline $06 / 23 / 03$ & 0.51 & 235 & - - & -- & - - \\
\hline $06 / 24 / 03$ & 0.52 & 235 & - - & -- & - - \\
\hline $06 / 25 / 03$ & 0.53 & 230 & -- & -- & - - \\
\hline $06 / 26 / 03$ & 0.58 & 228 & - - & -- & - - \\
\hline 06/27/03 & 0.51 & 227 & - - & -- & - - \\
\hline $06 / 28 / 03$ & 0.64 & 236 & -- & -- & - - \\
\hline $06 / 29 / 03$ & 0.63 & 235 & - - & -- & - \\
\hline $06 / 30 / 03$ & 0.75 & 238 & - - & -- & - - \\
\hline 07/01/03 & 0.68 & 238 & - - & -- & -- \\
\hline $07 / 02 / 03$ & 1.02 & 242 & -- & -- & - - \\
\hline 07/03/03 & 0.91 & 248 & -- & -- & - \\
\hline 07/04/03 & 0.92 & 246 & -- & -- & - - \\
\hline $07 / 05 / 03$ & 0.88 & 245 & -- & -- & - - \\
\hline 07/06/03 & 0.89 & 247 & -- & -- & - - \\
\hline 07/07/03 & 0.93 & 245 & -- & -- & -- \\
\hline 07/08/03 & 0.97 & 242 & -- & - - & - - \\
\hline 07/09/03 & 0.92 & 239 & - - & -- & - - \\
\hline 07/10/03 & 0.88 & 242 & -- & -- & -- \\
\hline $07 / 11 / 03$ & 0.92 & 243 & -- & -- & - - \\
\hline $07 / 12 / 03$ & 0.92 & 243 & - - & -- & - - \\
\hline 07/13/03 & 0.94 & 243 & - & -- & -- \\
\hline $07 / 14 / 03$ & 0.98 & 236 & - - & - & - - \\
\hline $07 / 15 / 03$ & 0.93 & 233 & - - & -- & - - \\
\hline 07/16/03 & 0.97 & 237 & -- & -- & -- \\
\hline $07 / 17 / 03$ & 0.95 & 238 & - - & -- & - - \\
\hline 07/18/03 & 0.72 & 246 & -- & -- & -- \\
\hline 07/19/03 & 0.44 & 273 & - - & -- & - - \\
\hline
\end{tabular}


Table D - 6. Daily mean flow velocities, MicroCAT water temperatures and specific conductances, and water depths at station GS-36 during deployment period 06/18/03 1300-07/30/03 1100-Continued

\begin{tabular}{|c|c|c|c|c|c|}
\hline Date & $\begin{array}{l}\text { Flow velocity }{ }^{1} \\
\text { (cm/s) }\end{array}$ & $\begin{array}{l}\text { Flow direction' } \\
\text { ( }{ }^{\circ} \mathrm{CW} \text { from MN) }\end{array}$ & $\begin{array}{c}\text { Temperature }{ }^{2} \\
\left({ }^{\circ} \mathrm{C}\right)\end{array}$ & 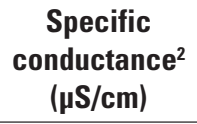 & $\begin{array}{l}\text { Water depth }{ }^{3} \\
\text { (cm) }\end{array}$ \\
\hline 07/20/03 & 0.39 & 273 & -- & -- & -- \\
\hline $07 / 21 / 03$ & 0.20 & 270 & - - & - & -- \\
\hline $07 / 22 / 03$ & 0.20 & 265 & - & - & -- \\
\hline $07 / 23 / 03$ & 0.23 & 268 & -- & -- & -- \\
\hline 07/24/03 & 0.24 & 268 & - & - & - - \\
\hline $07 / 25 / 03$ & 0.44 & 264 & - & - & -- \\
\hline 07/26/03 & 0.67 & 263 & -- & -- & -- \\
\hline $07 / 27 / 03$ & 0.65 & 259 & -- & -- & -- \\
\hline 07/28/03 & 0.55 & 264 & - & - & - \\
\hline 07/29/03 & 0.37 & 271 & -- & -- & -- \\
\hline MINIMUM & 0.20 & 227 & & & \\
\hline MAXIMUM & 1.02 & 273 & & & \\
\hline AVERAGE & 0.71 & 248 & & & \\
\hline $\begin{array}{l}\text { BURSTS } \\
\text { FILTERED } \\
\text { OUT }(\%)\end{array}$ & 0 & & & & \\
\hline
\end{tabular}

${ }^{1}$ Flow sample volume located $20 \mathrm{~cm}$ above top of litter.

${ }^{2}$ MicroCAT temperature and conductance measured $15 \mathrm{~cm}$ above top of litter.

${ }^{3}$ Depth variation determined from stage recorded at P36 gage. 


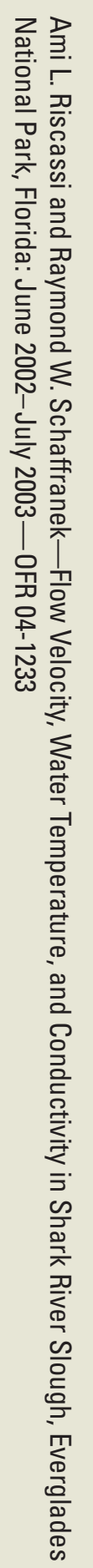

8 Printed on recycled paper 